\title{
Marília de Castro Torres-Fernandes
}

\section{MINISTÉRIO PÚBLICO EM SÃO PAULO: EFICÁCIA DA FUNÇÃO INSTITUCIONAL DE ZELAR PELO DIREITO À SAÚDE}

\begin{abstract}
Dissertação apresentada ao Departamento de Filosofia
e Teoria Geral do Direito da Faculdade de Direito da Universidade de São Paulo, para obtenção do título de Mestre.
\end{abstract}

Orientador:

Professor Dr. José Eduardo Campos de Oliveira Faria 


\section{SUMÁRIO}

\section{SIGLAS E ABREVIATURAS}

\section{INTRODUÇÃO}

1.1 Delimitação do objeto e explicitação de objetivos....................................... 01

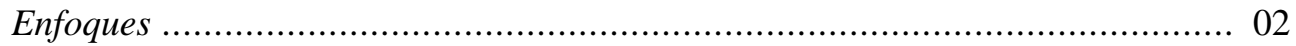

1.2 Procedimento metodológico …..................................................................... 04

Limites espacial, temporal e material ...................................................... 06

1.3 Justificativa da escolha e importância do tema ........................................ 09

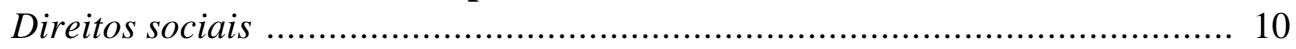

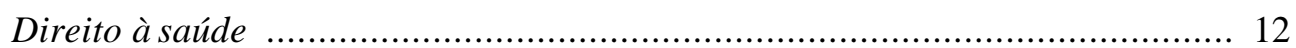

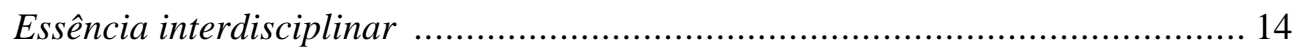

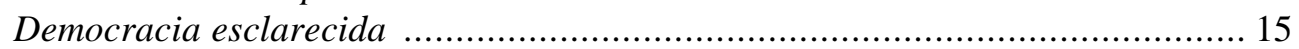

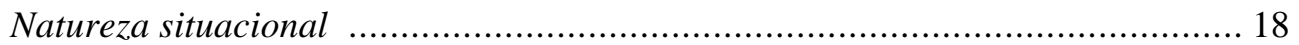

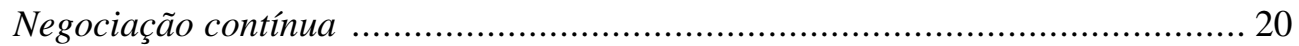

Execução e controle .............................................................................. 21

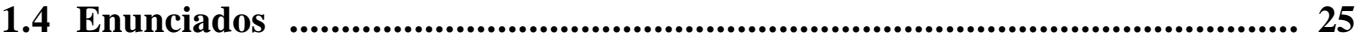

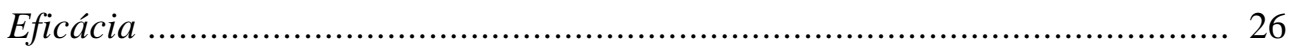

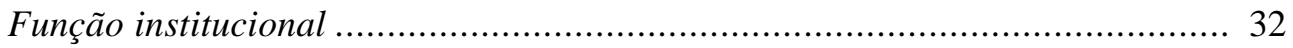

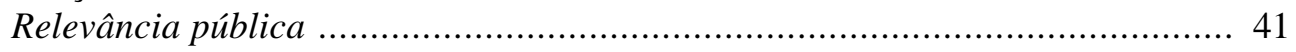

\section{COLETA DE DADOS}

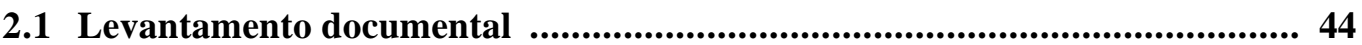

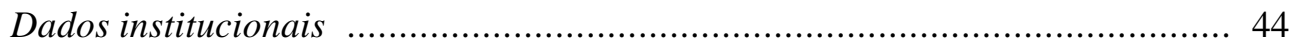

Princípios da unidade e indivisibilidade ............................................... 45

Princípio do promotor natural ............................................................ 46

Princípio da independência funcional ................................................. 46

Ministério Público Federal ............................................................... 48

Ministério Público Estadual ................................................................ 49

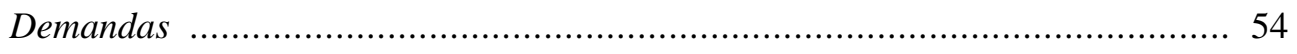

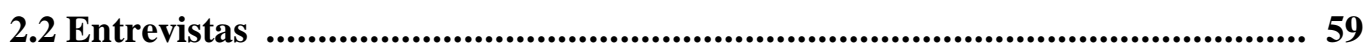

3. ANÁLISE

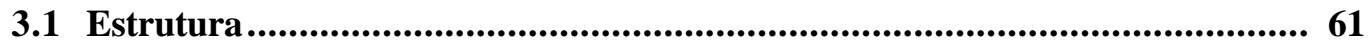

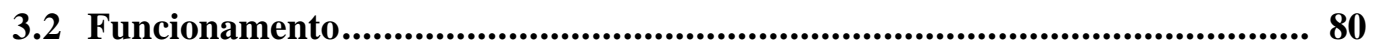

3.3 Dificuldades conceituais e operacionais .................................................. 94

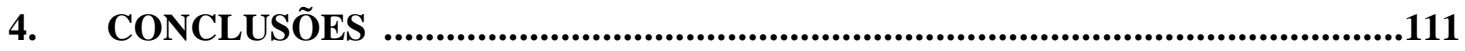

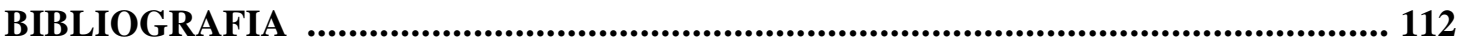

ANEXOS

Anexo $1 A$ - Demandas registradas no MPF ............................................................. $i$

Anexo $1 B$ - Demandas registradas no MPE .................................................... xiv

Anexo 2 - Roteiro de entrevistas .............................................................. xxix

\section{RESUMO / ABSTRACT}




\section{RESUMO}

O objetivo do trabalho consiste em verificar e analisar, no âmbito do Município de São Paulo, a eficácia do artigo 129, II, da Constituição Federal, que, combinado ao art.197, atribui ao Ministério Público a função institucional de zelar pelo efetivo respeito ao direito à saúde por parte dos Poderes Públicos e dos serviços de relevância pública. Analisaram-se a estrutura e o funcionamento institucionais no período compreendido entre 1988 e 1996, por meio de levantamento documental, acompanhamento de demandas e entrevistas. O primeiro capítulo procura justificar a escolha e importância do tema e enuncia os conceitos adotados de eficácia, função institucional e relevância pública, alicerces da pesquisa. O segundo capítulo descreve a execução da coleta de dados, independentemente da análise de seu conteúdo, apresentada no terceiro capítulo. Conclui-se pelo avanço institucional em direção ao cumprimento da norma enfocada, cuja eficácia, entretanto, ainda não se alcançou integralmente.

\section{ABSTRACT}

The purpose of this study was to analyse and verify, in the scope of São Paulo City, the effectiveness of art.129, II, of the Federal Constitution, which, combined with art.197, assigns to Public Attorneys the institutional function of ensuring the proper application of health laws by the Public Powers and services of public relevance. The institutional structure and functioning in the period between 1988 and 1996 were analysed through documental survey, follow-up of demands and personal interviews. The first chapter aims at justifying the importance of the theme, defining such concepts of efficacy, institutional role and public relevance as underlie the research. In the second chapter, the process of data collection is described, irrespective of content analysis, which will be the object of the third chapter. The conclusion is that some institutional advancement has been achieved towards better application of the rule at issue, without, however, having attained its entire effectiveness. 


\section{SIGLAS E ABREVIATURAS}

ACP Ação Civil Pública

AIH Autorização de Internação Hospitalar

ARS Administração Regional de Saúde

CCR Câmara de Coordenação e Revisão (MPF)

CDC Código de Defesa do Consumidor (Lei Federal nº 8.078/90)

CF Constituição da República Federativa do Brasil

CSMP Conselho Superior do Ministério Público (MPE)

CVS Centro de Vigilância Sanitária

DIR Direção Regional de Saúde

DS Distrito de Saúde

ERSA Escritório Regional de Saúde

FUMDES Fundo Municipal de Saúde

IC Inquérito Civil

LC Lei Complementar

LF Lei Federal

LOEMP Lei Orgânica Estadual do Ministério Público (LC Estadual-SP no 734/93)

LOMP Lei Orgânica Nacional do Ministério Público (Lei Federal no 8.625/93)

LOMPU Lei Orgânica do Ministério Público da União (LC 75/93)

LOS Lei Orgânica da Saúde (Leis Federais nº 8.080/90 e 8.142/90)

MP Ministério Público

MPE Ministério Público do Estado de São Paulo

MPF Ministério Público Federal

MPT Ministério Público do Trabalho

MPU Ministério Público da União

MS Ministério da Saúde

NOB Norma Operacional Básica

OMS Organização Mundial de Saúde

PAS Plano de Atendimento à Saúde

PFDC Procurador Federal dos Direitos do Cidadão

PJC-CAP Promotoria de Justiça dos Direitos Constitucionais do Cidadão - Capital

PMSP Prefeitura Municipal de São Paulo

PRDC Procurador Regional dos Direitos do Cidadão

PRM Procurador da República no Município

SES Secretaria de Estado da Saúde

SMS Secretaria Municipal de Saúde

SNVS Secretaria Nacional de Vigilância Sanitária

SOTC Secretaria dos Ofícios da Tutela Coletiva (MPF)

SUS Sistema Único de Saúde

UBS Unidade Básica de Saúde 


\section{INTRODUÇÃO}

Este trabalho tem por objetivo analisar a eficácia da função atribuída ao Ministério Público pela Constituição Federal de 1988 de zelar pelo efetivo respeito por parte dos Poderes Públicos e dos serviços de relevância pública ao direito constitucional à saúde, em São Paulo.

No esforço de tornar este texto legível tanto a profissionais do direito como da saúde, procurou-se dar a ele redação atenta a ambos os públicos, de modo a contribuir para a aproximação de uns e outros em torno de um tema que é interdisciplinar por natureza: o direito à saúde.

Conta-se com a paciência do leitor quanto ao uso, nesta introdução, de termos plurívocos que serão conceituados para efeito desta pesquisa no próprio corpo do trabalho. Em se tratando de introduções:

"há que se ir dizendo as coisas do direito sem poder pressupor que elas já sejam conhecidas. Mas, simultaneamente, é impossível falar sobre o direito sem usar os termos que, tecnicamente, o constituem." 1

\subsection{Delimitação do objeto e explicitação de objetivos}

Este trabalho tem como ponto de partida a combinação de dois artigos constitucionais: ${ }^{2}$

“Art. 129. São funções institucionais do Ministério Público: . .

II - zelar pelo efetivo respeito dos Poderes Públicos e dos serviços de relevância pública aos direitos assegurados nesta Constituição, promovendo as medidas necessárias à sua garantia;"

“Art. 197. São de relevância pública as ações e serviços de saúde, cabendo ao Poder Público dispor, nos termos da lei, sobre sua regulamentação, fiscalização e controle, devendo sua execução ser feita diretamente ou através de terceiros e, também, por pessoa física ou jurídica de direito privado.”

FERRAZ JR., T.S., 1988, Introdução.

Original sem grifos.

Obs.: é comum encontrar alusões equivocadas ao art.129, II, devido à sua má redação. Exemplos são encontrados em SILVA, J.A. (1992:514): "garantidor do respeito aos Poderes Públicos e aos serviços de relevância pública" e até no próprio material institucional lançado a título educativo pelo MP. Melhor redação seria "por parte dos Poderes Públicos e dos serviços de relevância pública". 
A dissertação que se pretende desenvolver tem por objetivo primário, ou essencial:

verificar e analisar a eficácia da norma constitucional que atribui ao Ministério Público a função institucional de zelar pelo efetivo respeito por parte dos Poderes Públicos e dos serviços de relevância pública em relação ao direito à saúde, no caso do Município de São Paulo.

Para alcançá-lo, podem-se considerar objetivos secundários, ou instrumentais:

1. levantar e acompanhar demandas em matéria de saúde documentadas no MP;

2. descrever o modo como o MP desempenha essa função de zelo no âmbito do universo estudado;

3. conhecer macro-estratégias da instituição para cumprir a atribuição em foco;

4. identificar eventuais dificuldades - teóricas ou práticas - apontadas pela própria instituição;

5. verificar se a atuação do MP nessa matéria tende a se concentrar no sistema de justiça ${ }^{3}$ ou a se expandir junto a outras instituições;

6. analisar o efeito destes resultados sobre a eficácia da norma.

\section{Enfoques}

Os objetivos enumerados como secundários ou instrumentais podem ser expressos metaforicamente como um roteiro que leva ao objetivo primário proposto. Explorando figurativamente essa idéia de roteiro, estes objetivos representam os pontos que irão mapeando o traçado dessa incursão no Ministério Público até um ponto final. Evidentemente, só se pode considerar atingido o ponto de chegada quando todas as metas intermediárias tiverem sido alcançadas. Por isso é imprescindível não perder de vista os parâmetros prédefinidos neste momento, de modo a não antecipar quaisquer impressões que possam levar a conclusões precipitadas.

Sistema de justiça compreendido como o "conjunto de todas as instituições que, juntamente com o Poder Judiciário, forma um sistema de promoção e acesso à justiça, como a Procuradoria do Estado, a Defensoria Pública, os advogados, o Ministério Público e a polícia judiciária", tomando-se aqui emprestada a formulação de MACEDO JR., R.P., 1995, para se referir a "aparelho judicial". 
Assim dispostos, os objetivos instrumentais apresentam uma dupla dimensão: ao mesmo tempo em que mantêm uma linearidade, pois serão percorridos seqüencialmente, oferecem ao observador um panorama de relevos distintos, enfocados sob diferentes ângulos:

\section{Perspectiva descritiva:}

revela o retrato da atuação institucional com base em dados (objetivos instrumentais 1, 2 e 3: levantamento de demandas, modo de atuação, macro-estratégias);

\section{Perspectiva crítica:}

permite apreciar a instituição sob a ótica interna (objetivo instrumental 4: dificuldades manifestas), ou sob a ótica externa (objetivo instrumental 5: inserção no sistema de justiça e interface com outras instituições);

\section{Perspectiva analítica:}

enseja reflexões sobre os resultados obtidos (objetivo instrumental 6: efeitos da atuação sobre a eficácia da norma).

Com isto, acredita-se ser possível apresentar conclusões agrupadas conforme as perspectivas acima, ao invés de apresentá-las item por item, mesmo porque, como já foi dito, os itens constituem apenas uma forma operacional de trabalhar dados e resultados que, desagregados, não serviriam senão para delinear os contornos externos do que se pretende oferecer como contribuição. A tarefa somente poderá ser considerada cumprida se o problema de pesquisa proposto como objetivo essencial redundar em conclusões reunidas de tal modo que se possa visualizar toda a paisagem a partir de um mapa assim construído. 


\subsection{Procedimento metodológico}

Em que pesem os pontos de contato entre o tema e as diversas disciplinas que o tangenciam, o trabalho pode ser situado no campo da sociologia jurídica, predominante em estudos que têm seu eixo temático centrado na verificação da eficácia de normas jurídicas. Esta inserção por si só determina abordagem metodológica própria desta disciplina, mesclando enfoques quantitativos e qualitativos, incluindo pesquisa de campo.

Sem entrar no mérito de discussões que envolvem a essência da sociologia jurídica, pressupõe-se aqui a interdisciplinariedade como condicionante da eficácia que se quer averiguar. Em aprofundada análise sobre o tema da sociologia jurídica, o Professor Celso Fernandes Campilongo afirma que

"'colaboração', 'mediação', 'investigação interdisciplinar' ou 'intercultural', 'articulação', 'denominador comum', são as palavras de ordem da disciplina."

E exemplifica:

"Hoje, nenhum campo do conhecimento deve jactar-se da 'especificidade' ou 'autonomia' de sua ciência. Os desavisados podem se assombrar com o fato de a Universidade de São Paulo organizar cursos de direito urbanístico na Faculdade de Arquitetura, direito sanitário na Faculdade de Saúde Pública ou direito ambiental no Instituto Oceanográfico. Mas na prática é impossível desenvolver esses campos do conhecimento jurídico isoladamente, sob o falso abrigo do purismo metodológico. É opinião quase comum - pois entre os juristas ainda há resistência a isso - que o processo de convergência entre as ciências humanas seja inevitável." 4

O estudo de caso como procedimento metodológico foi opção quase automática pela própria natureza da pesquisa, que busca responder às questões "como" e "por quê". As perguntas “como o MP desempenha a função que lhe é atribuída no art. 129, II, da CF” e "por que atua desse modo", uma vez respondidas, permitem avaliar a eficácia da norma constitucional em foco. Além disso, o estudo de caso é especialmente indicado quando se trata de pesquisa social empírica voltada a um fenômeno contemporâneo, ajustando-se perfeitamente ao objeto. A contribuição de um estudo de caso, em que pese o fato de as

4 CAMPILONGO, C.F., 1997, pp.17-18. 
conclusões alcançadas serem válidas apenas nos limites do universo estudado, consiste na possibilidade de se reconhecerem semelhanças e diferenças com relação a outros casos. ${ }^{5}$

A abordagem teórica será elaborada com base em pesquisa bibliográfica e a questão de fundo --- sobre estar a instituição formal e materialmente preparada para viabilizar o efetivo respeito pelo direito à saúde ---, com base em levantamento documental e entrevistas.

Para além do que aparece, do que está declarado ou explicitado, o que se pretende é verificar o que o art.129, II, representa, de fato, para seu destinatário, o Ministério Público. Esse significado implícito se manifesta nos casos concretos sujeitos à atuação do MP, focalizados e analisados globalmente. A abstração a partir dos fatos pode ser ilustrada pelas palavras do Professor Dalmo Dallari, ao tratar de outra instituição:

"Examinando-se os critérios adotados através da história para a escolha dos juízes, tem-se, implicitamente, conhecimento do papel atribuído à magistratura." 6

Analogamente, é o que se pretende extrair com relação ao MP. Parafraseando: examinando-se os critérios adotados para o encaminhamento das demandas, tem-se implicitamente, conhecimento do papel desempenhado pelo MP.

A documentação a ser levantada inclui não apenas o instrumental que descreve as características estruturais e funcionais do MP, mas principalmente o levantamento das demandas registradas e o acompanhamento da destinação dada às mesmas. As informações assim colecionadas serão acrescidas de impressões subjetivas dos membros do MP por meio de entrevistas, visando obter material que permita, por análise qualitativa, construir uma compreensão sistematizada e verossímil da atuação institucional.

Destaque-se o fato de que o $1^{\circ}$ Curso de Especialização em Interesses Difusos e Coletivos promovido pela Escola Superior do Ministério Público do Estado de São Paulo, ao longo de 1997, ofereceu excelente oportunidade de aprofundamento contínuo da reflexão teórica acerca do tema aqui tratado. Por representarem uma fonte significativa de questionamentos em grande parte formulados pelos próprios membros do MPE, as argumentações espontâneas de promotores e procuradores atuantes na área da saúde forneceram ao trabalho subsídios que talvez não fossem obtidos de forma provocada. As declarações recolhidas contribuíram em grande parte para reforçar, ou atenuar, algumas intuições e tendências subjetivas com relação à pesquisa, ainda que não se possa atribuir a esta experiência o rigor de uma técnica de observação, até porque não se dispôs de

YIN, R.K., 1984.

DALLARI, D.A., 1996, p.08. 
instrumento equivalente no âmbito federal, o que distorceria o procedimento metodológico em sua formulação teórica como um todo.

\section{Limite espacial}

O limite espacial está representado pelo Município de São Paulo. Ainda que se possa argumentar que o trabalho deixa de contemplar a atuação global do MP por se restringir à Capital do Estado, é preciso lembrar que se trata de um estudo de caso, cujo objetivo vai além da mera descrição de como a instituição atua em geral, para analisar em profundidade o conteúdo que um dado universo manifesta. É da natureza mesma da metodologia adotada investigar isoladamente as evidências recolhidas em uma única fonte, sem contaminações.

\section{Limite temporal}

Uma vez tomada a Constituição Federal por referência, o levantamento documental abrange o período compreendido entre a promulgação da Carta e o ano que marca o início dos trabalhos de campo, inclusive. Portanto, entre 1988 e 1996, totalizando 8 (oito) anos.

\section{Limite material}

Serão examinados o Ministério Público Estadual (MPE) e Federal (MPF) em seus aspectos tanto estruturais como funcionais, isto é: a forma de organização e distribuição interna de competências e o conteúdo das prioridades e diretrizes para o cumprimento de suas funções.

Optou-se por enfocar o direito à saúde exclusivamente sob o ponto de vista de seu fundamento, ou seja, como direito advindo da condição de pessoa humana considerada unicamente como tal, independentemente de eventuais relações de trabalho ou de consumo. Estas constituem circunstâncias em que a tutela é específica, sendo dispensável estudá-las quando o que se pretende é verificar a tutela genérica do direito à saúde. Tais situações foram excluídas do campo de estudo justamente porque não englobam os princípios de universalidade, igualdade e integralidade que norteiam esse direito. ${ }^{7}$

Outro recorte da pesquisa é a prioridade à atuação institucional até o momento em que a medida ingressa na arena judicial. O que se pretende é focalizar o MP e não exatamente os

\footnotetext{
7 Constituição Federal, art.196
} 
resultados que ele tem obtido junto ao Judiciário. Importa especialmente conhecer as medidas extrajudiciais tomadas pelo MP antes de ajuizar uma ação, buscando saber se e por quê tais medidas são consideradas satisfatórias ou insuficientes. Isto possibilita verificar a tendência do Ministério Público quanto à relativização do Judiciário como última --- e não a única --instância de garantia de direitos.

Em uma versão anterior deste projeto, procedeu-se a pesquisa exploratória que permitisse vislumbrar o universo de decisões judiciais em matéria de direito à saúde. O resultado foi que a amostragem colhida à época apresentou uma escassez quase absoluta de demandas dessa natureza, ao ponto de inviabilizar a análise de conteúdo que se pretendia quanto a uma suposta tendência jurisprudencial. A questão que imediata e inevitavelmente se colocou foi conhecer o trajeto dos conflitos desde a porta de entrada do sistema de justiça, deslocando o foco de atenção do Judiciário, onde o direito encontra suas condições últimas de garantia, para o MP, onde tem condições de começar a se efetivar.

Esta, aliás, é a razão pela qual a atuação da área penal relativa aos crimes contra a saúde pública também não integra o escopo deste trabalho: justamente porque é exercida a posteriori, dada sua essência repressiva, estando já coberta pelo inciso I do art.129 (promoção privativa da ação penal pública), cuja eficácia não se está procurando avaliar.

A função de zelo no caso de direitos sociais não se restringe à atuação perante a Justiça, porque exige mais, exige visão prospectiva voltada ao planejamento de atividades de promoção e prevenção. O objetivo da norma que designa a uma instituição a tarefa de zelar pelo direito à saúde não é obter satisfação retributiva daqueles que violaram normas penais relativas à saúde. Embora a repressão possa servir como instrumento de dissuasão e, nesse sentido, possa encerrar um caráter preventivo, não será a polícia judiciária que garantirá saúde à população, mas sim a intervenção, em tempo, da polícia administrativa exercida pela vigilância sanitária.

O fato de haver órgãos especializados na área penal representa apenas uma especialização para fins operacionais de tutela do mesmo direito à saúde por um meio diverso, direcionado a um único aspecto, mas que ainda pode ser amplamente considerado como zelo por parte dos Poderes Públicos e dos serviços de relevância pública.

Em outras palavras, há uma curiosidade específica a respeito da atuação preventiva e de seus efeitos nos casos concretos. Para além destes efeitos diretos, interessam possíveis efeitos paralelos sobre a instituição como um todo: assim, por exemplo, a preocupação em atuar preventivamente como forma de promover uma gradual difusão pedagógica dos instrumentos jurídicos nem sempre conhecidos e utilizados por seus titulares. A longo prazo, uma política 
institucional como esta poderia eventualmente trazer a sociedade a um nível mais elevado de emancipação e o próprio MP a uma atuação mais seletiva.

Reforça este recorte o fato de já haver estudos que tratam especificamente dos aspectos judiciais relativos aos direitos sociais, notadamente no campo do direito processual, destacando-se o trabalho apresentado como dissertação de mestrado pelo Promotor de Justiça Carlos Alberto de Salles, que traz como uma de suas conclusões:

"a atribuição do art.129, II, da Constituição Federal não contém apenas um significado de atuação processual, mas inclui uma atividade fiscalizatória geral a cargo do Ministério Público, podendo-se configurar esta instituição a partir da função de controle." 8

Este parece ser um entendimento que vem sendo corroborado em publicações mais recentes, elaboradas por vários membros do $\mathrm{MP}$, como demonstra a afirmação de que o Ministério Público

“passa a assumir a responsabilidade pela solução (não necessariamente processual, nem mesmo judicial) dos problemas e questões de sua alçada. Em outras palavras, assume a responsabilidade pela defesa direta e imediata dos interesses confiados a sua tutela." 9 


\subsection{Justificativa da escolha e importância do tema}

"Em primeiro lugar, a crise da saúde não constitui privilégio do Brasil, nem sequer dos países em desenvolvimento, sendo, portanto, universal. Em segundo, ela manifesta-se nas dimensões da ineficiência, da ineficácia, da iniqüidade e da insatisfação da opinião pública." 10

A temática relativa aos sistemas de saúde, quer se trate de execução direta pelo Poder Público ou de fiscalização e controle sobre os serviços privados, há muito tem sido recorrente tanto em estudos acadêmicos como em levantamentos estatísticos e pesquisas comparativas, redundando inclusive em análises internacionais, a exemplo do relatório "Investindo na Saúde", do Banco Mundial. ${ }^{11}$

Também não são poucas na mídia as notícias que diariamente apontam decisões políticas as mais variadas para dar conta de problemas envolvendo a área da saúde, fato notório que aos próprios governantes aflige, especialmente no que tange às falhas do setor. ${ }^{12}$

Sejam quais forem os fatores que contribuem para esse estado de coisas, entre os quais pode-se mencionar a crise fiscal do Estado, as novas tecnologias de altíssimo custo e as crescentes demandas cada vez mais diversificadas, o fato é que ainda se presencia um notório distanciamento entre o modelo constitucional do Sistema Único de Saúde (SUS) e o efetivo exercício do direito à saúde.

A relevância do tema escolhido advém da própria história da positivação do direito à saúde no Brasil, desde quando era nada mais que uma aspiração até a instituição de meios para sua execução e controle.

"Quando os direitos do homem eram considerados unicamente como direitos naturais, a única defesa possível contra a sua violação pelo Estado era um direito igualmente natural, o chamado direito de resistência. Mais tarde, nas Constituições que reconheceram a proteção jurídica de alguns desses direitos, o direito natural de resistência transformou-se no direito positivo de promover uma ação judicial contra os próprios órgãos do Estado." 13

No caso do direito à saúde, esta transformação envolve conquistas literalmente vitais.

10 MENDES, E.V., 1996, p.15.

11 BANCO MUNDIAL / Banco Internacional para Reconstrução e Desenvolvimento, 1993.

12 Exemplo emblemático é o Plano de Atendimento à Saúde (PAS), apresentado como proposta revolucionária e causadora de várias polêmicas, plano esse que, após um ano de implementação no Município de São Paulo, enfrenta crise considerada grave pelo próprio Secretário Municipal de Saúde, sendo a ineficiência gerencial apontada como uma de suas falhas mais sérias (Folha de S.Paulo, 16.II.97, Caderno São Paulo, p.6).

13 BOBBIO, N., 1992, p.31. 
Avaliar e aprimorar a eficácia dos meios para a realização de ideal tão sólido constitui a justificativa primeira e última de todos que têm se dedicado a mantê-lo presente e a lhe dar continuidade. Para isto, nunca é demais relembrar alguns progressos.

\section{Direitos sociais}

É já hoje corriqueira a referência a direitos de primeira e segunda geração para diferenciar direitos civis e políticos, voltados à garantia da liberdade individual, dos direitos sociais, voltados à garantia da igualdade entre os indivíduos. Entre o surgimento dos primeiros e dos segundos, mudanças sociais fizeram-se refletir sobre as concepções mesmas de sociedade, Estado e direito, trazendo conseqüências ainda objeto de discussão.

O sistema jurídico brasileiro sofreu momentos de grandes contradições quando da inserção de normas destinadas à proteção de direitos coletivos: o arcabouço legal que tradicionalmente atribuía ao Estado, de inspiração liberal, funções de justiça comutativa, intervindo na vida particular apenas para manter a ordem, passou a conviver mais e mais com normas que exigiam iniciativas estatais positivas de justiça distributiva, mediante planejamento e políticas econômicas e sociais que garantissem os chamados novos direitos, de natureza metaindividual.

"A necessidade de solução pacífica do conflito de interesses difusos, e sua tutela pelo ordenamento jurídico, são indiscutíveis. Trata-se de interesses de massa, relativos à defesa do meio ambiente, à proteção de valores culturais e espirituais, à tutela do consumidor. E exatamente por sua configuração coletiva e de massa, caracterizam-se por uma conflituosidade, também de massa, que não se coloca no clássico contraste indivíduo $\mathrm{x}$ autoridade, mas que é típica das escolhas políticas. Quando a poluição de um rio afeta as populações ribeirinhas; quando laboratórios químicos falsificam produtos farmacêuticos; quando indústrias alimentícias fraudam milhares de consumidores; quando complexos industriais poluem bairros e cidades; quando petroleiros provocam danos ecológicos ou predadores exterminam a fauna; quando a indústria edilícia deteriora o patrimônio artístico, histórico ou turístico, verifica-se de maneira contundente e até trágica a necessidade imperiosa e urgente de não deixar sem tutela esses interesses comuns.

Por outro lado, ao grupo titular de um interesse costuma-se contrapor o interesse de outro grupo. O interesse à contenção dos custos de produção e dos preços contrapõe-se ao interesse à criação de novos postos de trabalho, à duração dos bens colocados no comércio, etc. $\mathrm{O}$ interesse à preservação das belezas naturais contrapõe-se ao interesse da indústria edilícia, ou à destinação de áreas verdes a outras finalidades; o interesse ao 
transporte automobilístico não poluente e barato contrapõe-se ao interesse por um determinado tipo de combustível; o interesse à informação correta e completa contrapõese ao interesse político em manter um mínimo de controle sobre os meios de comunicação de massa, etc.

Salta à vista o aspecto político da tutela dos interesses difusos, na medida em que é evidente que os procedimentos normais de mediação do sistema político mostraram sua insuficiência, daí resultando o conflito de massa.

O problema fundamental da proteção desses novos interesses reside, assim, na correta colocação institucional dos procedimentos de mediação que têm por objeto a solução de conflitos metaindividuais." 14

A saúde surge como um dos temas que mais tipicamente exemplifica essa ampliação: as inovações introduzidas pela Constituição Federal de 1988 afetaram significativamente a concepção de direito à saúde, declarado pela primeira vez como direito de todos.

Para que se tenha uma idéia do tratamento diferenciado que recebeu a matéria, basta que se faça uma comparação "topográfica", por assim dizer, entre sua localização na Constituição vigente e na anterior.

Dispunha a CF de 1967/69, ao tratar da Organização Nacional, que competia à União "estabelecer e executar planos nacionais de educação e de saúde, bem como planos regionais de desenvolvimento", além de legislar sobre normas gerais de defesa e proteção da saúde. ${ }^{15}$ Mais adiante, no título sobre a Ordem Econômica e Social, a mesma CF assegurava aos trabalhadores o "direito à assistência sanitária, hospitalar e médica preventiva". ${ }^{16}$ Comentava então a Professora Sueli Gandolfi Dallari:

"(...) A Constituição Federal, que é a lei maior que condiciona todas as outras leis, decretos e portarias existentes no Brasil, não declara expressamente que o Estado brasileiro reconhece o direito à saúde. Entretanto ela assegura aos trabalhadores o direito à assistência sanitária, hospitalar e médica preventiva. Isso significa que qualquer trabalhador no Brasil tem direito de exigir do Estado as condições para melhorar seu estado de saúde, mas apenas o trabalhador. Isto é, o Brasil não garante constitucionalmente a todos os brasileiros o direito à saúde. É o que acontece formalmente, no plano das leis." ${ }^{17}$

GRINOVER, Ada Pellegrini. "A problemática dos interesses difusos". In: GRINOVER, A.P., 1984, p.31.

${ }^{15}$ CF $1967 / 69$, art. $8^{\circ}$, XIV e XVII, "c".

16 CF $1967 / 69$, art. 165, XV.

17 DALLARI, S.G., 1987, p.12. 
Já na atual Constituição, a saúde consta como direito social, ${ }^{18}$ sob o título dos Direitos e Garantias Fundamentais, recebendo tratamento detalhado em seção própria da Saúde, dentro do capítulo da Seguridade Social. Comenta o Professor José Afonso da Silva:

"(...) É espantoso como um bem extraordinariamente relevante à vida humana só agora é elevado à condição de direito fundamental do homem. (...) O tema não era de todo estranho ao nosso Direito Constitucional anterior, que dava competência à União para 'legislar sobre defesa e proteção da saúde', mas isso tinha sentido de organização administrativa de combate às endemias e epidemias. Agora é diferente, trata-se de um direito do homem." 19

Um dos principais impactos dessa mudança foi o rompimento, de uma vez por todas, da clássica dicotomia entre direito público e direito privado, com a criação de microssistemas jurídicos cujos objetos se interpenetram formando como que uma rede de "pluritutela normativa":

"Como primeira característica, os novos Direitos, como o Direito da Saúde, transitam por todos os demais ramos do direito, v.g., o Direito Administrativo, o Direito Ambiental, o Direito do Consumidor, o Direito do Trabalho, o Direito da Seguridade Social, sem mencionar o Direito Constitucional, disciplina obrigatória para qualquer matéria jurídica." 20

\section{Direito à saúde}

Não é à toa que temos sido expostos a uma variada gama de expressões como direito à saúde, direito de saúde, direito da saúde, direito da saúde pública, direito sanitário.

A concepção atual de saúde está assim enunciada pela OMS:

"saúde é o completo bem-estar físico, mental e social, e não apenas a ausência de doença ou outros agravos." 21

A saúde assim amplamente concebida constitui a finalidade última de toda e qualquer política de saúde, dando unidade a todas elas, sejam quais forem suas especificidades. É justamente a partir dessa amplitude que se instala a dificuldade da conceituação do direito que lhe corresponde:

“Ao começar a definir o direito à saúde, enfrentaremos uma série de dificuldades. É muito mais confortável falar sobre assistência à saúde do que falar sobre saúde, porque

$\mathrm{CF}$, art. $6^{\circ}$.

9 SILVA, J.A., 1992, p.276.

20 ROCHA, J.C.S., 1999, pp.51-53.

21 Constituição da Organização Mundial da Saúde, 1946. 
saúde é algo que se situa além do nosso controle. Odireito à boa saúde parece tão significativo quanto um direito a ser feliz no amor!" 22

Ainda que o direito à saúde não signifique propriamente o direito ao bem-estar, mas às condições de alcançá-lo, não há dúvida de que esse ideal é que norteia a norma, que justifica a declaração da saúde como direito. É um direito que se cumpre dos mais diversos modos, nos mais diferentes graus, assumindo tantas formas quantas forem as possibilidades de aplicação, mas sempre com um único critério: estará tanto mais cumprido quanto mais os indicadores sociais refletirem condições para se atingir um completo bem-estar físico, mental e social. A partir de tais indicadores é que se torna possível mensurar quão distante se está desse ideal, identificar necessidades a serem supridas e então planejar políticas que atendam à finalidade da norma.

Há portanto uma relação direta entre este conceito de saúde e as políticas públicas que a garantem:

"A saúde é direito de todos e dever do Estado, garantido mediante políticas sociais $\boldsymbol{e}$ econômicas que visem à redução do risco de doença e de outros agravos e ao acesso universal e igualitário às ações e serviços para sua promoção, proteção e recuperação." 23

Essa relação é que faz da saúde um bem cuja tutela necessariamente há de ser coletiva. Evidentemente, asaúde é atributo individual, e constitui-se portanto no direito conferido a cada pessoa de exigir do Estado que as condições para gozar de boa saúde lhe sejam garantidas --- o chamado direito subjetivo público ---, mas essa garantia somente é realizável por meios coletivos: não é possível garantir condições de saúde a um único indivíduo sem garantia equivalente a todos os outros que partilham com ele do mesmo ambiente. Essa confluência das duas dimensões do direito à saúde, a individual e a coletiva, é que permite estabelecer algum critério na utilização das diferentes expressões adotadas neste trabalho:

Direito à saúde designa o direito assegurado pela Constituição a todas as pessoas humanas a exigirem do Estado condições para gozar de boa saúde, seja essa exigência exercida individualmente, pelo titular de direito subjetivo público, ou coletivamente, por entidades legitimadas para tanto, por via reflexa. ${ }^{24}$

Já o direito da saúde, ou direito da saúde pública, constitui um desdobramento do direito à saúde, designando o conjunto de normas jurídicas que definem os meios de

22 NUSSBAUM, Martha. In: Harvard Law School, 1995, p.34. Tradução livre.

23 CF, art. 196. Original sem grifos.

24 MANCUSO, R.C., 1991, p.54. 
concretizá-lo, desde a definição dos aspectos organizacionais e operacionais do sistema de saúde, o estabelecimento da forma e dos critérios a serem observados na formulação e implementação das políticas de saúde até as normas específicas atinentes a bens e serviços de interesse à saúde.

Por fim, denomina-se direito sanitário o estudo interdisciplinar que permite aproximar conhecimentos jurídicos e sanitários.

\section{Essência interdisciplinar}

"A matéria do direito sanitário não pode também restringir-se ao jurídico, uma vez que a regra de direito deriva da realidade social e nela encontra as condições de eficácia." ${ }^{25}$

Esta vinculação da eficácia das regras de direito aos fatos sociais é já clássica no pensamento jurídico. No caso do direito à saúde há ainda especificidades reais que acrescem experiência histórica a essa teoria:

“(....) os Estados passam a ser responsabilizados pela situação de saúde do povo, inicialmente por pressão dos industriais que exigiam que a manutenção de seus estoques de mão-de-obra não lhes custasse diretamente nada e que eles fossem protegidos do risco de epidemias. Posteriormente também o operariado pressionou para que o Estado, superior aos industriais, fiscalizasse as condições de saúde no trabalho.

Modernamente se exige do Estado a responsabilização pela saúde do povo porque se sabe que a saúde não é apenas a ausência de doenças mas o completo bem-estar físico, mental e social. Isto é, só tem saúde quem está bem adaptado ao seu ambiente geral. Para tanto não é suficiente a participação do Estado apenas promovendo boas condições de trabalho. É necessário que ele promova também boas condições de estudo, transporte, alimentação, moradia, lazer etc." 26

O próprio sistema de saúde atual é concebido sob tal premissa, assim refletida na lei:

"a saúde tem como fatores determinantes e condicionantes, entre outros, a alimentação, a moradia, o saneamento básico, o meio ambiente, o trabalho, arenda, a educação, o transporte, o lazer e o acesso aos bens e serviços essenciais." ${ }^{27}$

Tratando-se de um direito cujo sentido é aberto, ou seja, um direito que não tem um conteúdo em tese, unívoco, mas adquire significados diversos conforme demandas localizadas, o direito à saúde exige de quem por ele deva zelar um contato estreito com a

5 DALLARI, S.G., 1988(b), p.333.

DALLARI, S.G., 1987, pp.8-9.

LOS 8.080/90, art.3 $3^{\circ}$. Original sem grifos. 
realidade em que deve ser garantido, uma vez que a identificação das necessidades locais constitui requisito essencial para a definição de prioridades em políticas minimamente eficazes. O que faz da essência plurívoca do direito à saúde um aspecto irresistivelmente convidativo para um estudo desta natureza é justamente o ter-se atribuído ao MP uma função que exige do profissional do direito não apenas a compreensão teórica das normas que afetam a área da saúde --- o que, diga-se de passagem, já não é nada simples, considerando as inúmeras interfaces com normas das mais variadas áreas ---, mas também e principalmente o conhecimento do contexto em que serão aplicadas.

Neste cenário é que se abre novo campo de investigação: verificar as condições de eficácia da norma constitucional que atribui ao MP a função de zelar por direitos cuja garantia demanda monitoramento contínuo e efetivo das políticas públicas relacionadas à saúde, tarefa que freqüentemente pressupõe o domínio de legislações complexas e atuação conjunta com a população:

"Para que as regras referentes à saúde do povo reflitam realmente a vontade geral dessa sociedade é necessário que ela conheça qual sua situação sanitária e quais os meios de que ela pode dispor para alterá-la para, então, determinar quais os objetivos e os meios de atingi-los. E foi, também, para dispor dessas informações que permitem decisão segura que a sociedade formou o sanitarista. Espera-se, portanto, no Estado contemporâneo, que o sanitarista oriente a feitura das leis que conformam o direito da saúde públic a." 28

\section{Democracia esclarecida}

Presentes aqui dois dos mais importantes critérios reconhecidos na legislação para que uma política de saúde seja reputada juridicamente válida hoje: o primeiro requisito, técnico, é que tenham sido observados indicadores de saúde como perfil demográfico da região e perfil epidemiológico da população a serem cobertas, características quantitativas e qualitativas da rede de saúde da área etc.; ${ }^{29}$ o segundo requisito, estrutural, é que tal política de saúde tenha sido objeto de deliberação pelas instâncias colegiadas de participação da comunidade.

\footnotetext{
28 DALLARI, S.G., 1988(b), p.331.
}

29 LOS 8.080/90, art. 35. 
Destaque-se a importância dada à interlocução e à decisão conjunta de técnicos da saúde e leigos na área:

“Art. $1^{\circ}$ - O Sistema Único de Saúde (SUS), de que trata a Lei nº 8.080, de 19 de setembro de 1990, contará, em cada esfera de governo, sem prejuízo das funções do Poder Legislativo, com as seguintes instâncias colegiadas:

I - a Conferência de Saúde; e

II - o Conselho de Saúde.

$\S 1^{\circ}$ - A Conferência de Saúde reunir-se-á a cada quatro anos com a representação dos vários segmentos sociais, para avaliar a situação de saúde e propor as diretrizes para a formulação da política de saúde nos níveis correspondentes, convocada pelo Poder Executivo ou, extraordinariamente, por esta ou pelo Conselho de Saúde.

$\S 2^{\circ}$ - O Conselho de Saúde, em caráter permanente e deliberativo, órgão colegiado composto por representantes do governo, prestadores de serviço, profissionais de saúde e usuários, atua na formulação de estratégias e no controle da execução da política de saúde na instância correspondente, inclusive nos aspectos econômicos e financeiros, cujas decisões serão homologadas pelo chefe do poder legalmente constituído em cada esfera de governo." 30

Um breve relato de quem vivenciou a mobilização social que redundou nesse modelo é bastante elucidador do quanto é cara a combinação de princípios democráticos e técnicos:

"Em março de 1986, ocorreu o evento político-sanitário mais importante da década, a VIII Conferência Nacional de Saúde, para o qual confluiu todo o movimento encetado desde o início dos anos 70.

Essa conferência difere das demais, até então realizadas, por duas características principais. Uma, o seu caráter democrático, pela significativa presença de milhares de delegados, representativos de quase todas as forças sociais interessadas na questão saúde. Outra, sua dinâmica processual, que se iniciou por conferências municipais, depois estaduais, até chegar ao âmbito nacional.

A VIII Conferência Nacional de Saúde, que teve desdobramento imediato num conjunto de trabalhos técnicos, desenvolvidos pela Comissão Nacional da Reforma Sanitária, passou, com sua doutrina, expressa em seu relatório final, a constituir-se no instrumento que viria a influir de forma determinante em dois processos que se iniciaram, concomitantemente, em 1987: um, no Executivo, a implantação do Sistema Unificado e Descentralizado de Saúde, o SUDS; outro, no Congresso Nacional, a elaboração da nova Constituição Federal.

${ }^{30}$ LOS 8.142/90. Original sem grifos. 
O SUDS avançou para a desconcentração estadualizada da saúde e da municipalização dos serviços. Ao mesmo tempo, no Congresso Nacional, construía-se, pelo consenso possível das forças sociais aí representadas, o desenho constitucional da saúde.

De fato, a Constituição de 1988 incorporou um conjunto de conceitos, princípios e diretivas extraídos da prática corrente e hegemônica, mas reorganizando-os na nova lógica referida pelos princípios da reforma sanitária.

A saúde na Constituição é definida como resultante de políticas sociais e econômicas, como direito de cidadania e dever de Estado, como parte da seguridade social e cujas ações e serviços devem ser providos por um Sistema Único de Saúde, organizado segundo as seguintes diretrizes: descentralização, mando único em cada esfera de governo, atendimento integral e participação comunitária. Ao mesmo tempo, o Art.199 consagra a liberdade da iniciativa privada.

Estava criado, constitucionalmente, o Sistema Único de Saúde, que veio a ser regulamentado pelas Leis 8.080, de 19 de setembro de 1990 e 8.142, de 28 de dezembro de 1990." 31

Uma vez instalados canais internos de controle social sobre a efetividade das normas que o próprio sistema de saúde produz, não é de se esperar que o MP disponha de conhecimentos técnico-sanitários para avaliar o teor das políticas públicas de saúde, mas sim que cumpra sua atribuição de zelar para que o sistema de saúde seja ele me smo efetivado.

A adequação, eficiência, segurança ou qualidade das ações e serviços de saúde serão objeto de controle pelos mecanismos democráticos de deliberação legalmente previstos, de tal forma que as políticas sejam planejadas em consonância com as prioridades identificadas pelos próprios destinatários, devidamente esclarecidos quanto às tecnicalidades de sua situação de saúde.

31 MENDES, E.V., p.62. Original sem grifos. 


\section{Natureza situacional}

É justamente a natureza mutável das 'situações' de saúde o fator que mais merece atenção no funcionamento do sistema, pela simples razão de que constituem a essência material do direito que se quer proteger. A característica situacional é nuclear na própria conceituação do direito da saúde:

"sistema de normas jurídicas que disciplinam as situações que têm a saúde por objecto imediato ou mediato e regulam a organização e o funcionamento das instituições destinadas à promoção e defesa da saúde.” 32

A necessidade de se atentar para a descentralização decorre justamente disto. Como se percebeu no histórico acima, reconheceu-se (finalmente) que não se podem alcançar soluções à distância, sem que cada problema local seja analisado em profundidade: evidentemente, quem o vivencia se encontra em posição privilegiada de observação, porque mais próxima dos fatos. Só isto já seria suficiente para justificar a participação da comunidade local em decisões do gênero, não fosse o fato de ser essa mesma comunidade que terá de conviver com as conseqüências, sejam elas quais forem.

"Uma organização de saúde, nacional ou central, pode servir como orientação e guia para as autoridades sanitárias locais, ou prestar serviços técnicos inexistentes naquele nível. Mas o êxito de qualquer programa de saúde pública depende do seu grau de proximidade do público, e do entendimento, do programa, que esse público alcança. O preâmbulo da Constituição da Organização Mundial da Saúde afirmou esse princípio: 'Uma opinião informada e a colaboração do público são de importância extrema para a melhoria da saúde do povo'. Nessa afirmação está implícita a reciprocidade de direitos e deveres compartilhados pelo indivíduo e pela comunidade. É necessária, em suma, a participação de cada membro de uma comunidade na obra de melhoria da saúde individual e coletiva. Para esse propósito, a educação em saúde representa o instrumento fundamental." 33

Por outro lado, a análise dos problemas com algum distanciamento pode compensar eventuais visões distorcidas por comprometimentos pontuais. Assim, o ideal é que ambas as perspectivas sejam conjugadas para identificar os problemas, seus fatores determinantes, medidas prioritárias, interesses e conflitos envolvidos e possibilidades de atuação. E disto decorre a necessidade de se atentar para a descentralização como valor não absoluto, mas

32 CORREIA, S., 1991, p.41.

33 ROSEN, G., 1994, p. 335. Original sem grifos. 
como diretriz de uma rede regionalizada e hierarquizada, constituindo-se num sistema único (CF, art.198).

A constatação por vários autores de que primeiro é necessário singularizar o significado -- originalmente aberto -- dos direitos humanos, para depois concretizá-los plural e eqüitativamente parece levar à conclusão de que a escolha dos fins conforme as situações representa uma rotatividade infinita de variáveis, ao passo que o meio para garanti-las é sempre o mesmo e constante exercício de cidadania. Alguns argumentos exemplificam essa constatação:

“(....) embora indispensáveis à dignidade do homem em qualquer fase de sua vida, em qualquer sociedade e em qualquer lugar, os Direitos Humanos só são definidos em cada sociedade, em determinado período histórico. Muito mais que ideais, os Direitos Humanos são resultado do conjunto de dados da realidade, que dependem fundamentalmente da relação dos indivíduos que compõem uma sociedade entre si e desses com seu governo. É por isso que se diz que os Direitos Humanos são constantemente objeto de luta - se ganha ou se perde a cada geração." 34

“A meu ver, não há oposição para o trabalho no nível do sistema de saúde entre a abordagem sistêmica e a abordagem histórica. Esta última vem sendo proposta, com freqüência, na América Latina em projetos de inovação no ensino médico e odontológico, ou em sistemas de saúde. Sua debilidade, se usada isoladamente, é que ela é mais explicativa que instrumental para atuação em nível do sistema de saúde. Já a abordagem sistêmica é mais operativa, favorece a ação imediata. Parte ela dos dados da realidade atual através da análise situacional, incluindo nesta as coações do supra-sistema, e com base em uma dada visão do futuro propõe uma fórmula de atuação imediata.

A abordagem histórica tende a proporcionar uma visão determinística do futuro, enquanto a abordagem sistêmica tende a adotar uma visão não-determinística e a escolher um 'futuro desejado' dentre os vários futuros possíveis." 35

“O problema fundamental em relação aos direitos do homem, hoje, não é tanto o de justificá-los, mas o de protegêe-los. Trata-se de um problema não filosófico, mas político.

(....) Nossa tarefa, hoje, é muito mais modesta, embora também mais difícil. Não se trata de encontrar o fundamento absoluto --- empreendimento sublime, porém desesperado ---, mas de buscar, em cada caso concreto, os vários fundamentos possíveis. Mas também essa busca dos fundamentos possíveis --- empreendimento

34 DALLARI, S.G., 1987, p.8. Original sem grifos.

5 CHAVES, M.M., 1980, p.VII. 
legítimo e não destinado, como o outro, ao fracasso --- não terá nenhuma importância histórica se não for acompanhada pelo estudo das condições, dos meios e das situações nas quais este ou aquele direito pode ser realizado. Esse estudo é tarefa das ciências históricas e sociais. O problema filosófico dos direitos do homem não pode ser dissociado do estudo dos problemas históricos, sociais, econômicos, psicológicos, inerentes à sua realização: o problema dos fins não pode ser dissociado do problema dos meios." 36

\section{Negociação contínua}

O 'problema dos meios', tal como se apresenta hoje, consiste em que, justamente porque as normas de conteúdo aberto dependem de efetivo exercício democrático para serem definidas conforme as situações em cada caso concreto, quando isto não ocorre, não podem ser consideradas completas e executáveis.

Guardadas as devidas proporções, a definição do conteúdo do direito à saúde em cada situação reinicia constantemente um processo de negociação política semelhante àquele que redundou no reconhecimento da saúde como direito.

"O problema do fundamento de um direito apresenta-se diferentemente conforme se trate de buscar o fundamento de um direito que se tem ou de um direito que se gostaria de ter. No primeiro caso, investigo no ordenamento jurídico positivo, do qual faço parte como titular de direitos e de deveres, se há uma norma válida que o reconheça e qual é essa norma; no segundo caso, tentarei buscar boas razões para defender a legitimidade do direito em questão e para convencer o maior número possível de pessoas (sobretudo as que detêm o poder direto ou indireto de produzir normas válidas naquele ordenamento) a reconhecê-lo." 37

Não se pode dizer que o direito à saúde é um direito que se exercita passiva e tranqüilamente: de fato, há no ordename nto jurídico positivo do qual os brasileiros fazem parte como titulares de direitos e deveres uma norma válida que o reconhece, mas ainda assim cada um terá de buscar boas razões para convencer o maior número possível de pessoas (sobretudo as que detêm o poder direto ou indireto de produzir normas válidas) a reconhecerem a prioridade da sua situação específica.

O problema está nas dificuldades fáticas de implementação do direito, na medida em que a prática da cidadania brasileira é ainda incipiente.

"Deve-se recordar que a luta pela afirmação dos direitos do homem no interior de cada

36 BOBBIO, N., 1992, p.24. Grifos itálicos no original, sem grifos negritados. 
Estado foi acompanhada pela instauração dos regimes representativos, ou seja, pela dissolução dos Estados de poder concentrado." 38

No entanto, é preciso não confundir o problema dos meios com com a inexeqüibilidade dos fins, ou se estará correndo o risco de, como popularmente se diz, 'jogar a criança com a água da bacia'.

“O SUS, entendido como processo social em marcha, não se iniciou em 1988, com a consagração constitucional de seus princípios, nem deve ter um momento definido para seu término, especialmente se esse tempo está dado por avaliações equivocadas que apontam para o fracasso dessa proposta. Assim, o SUS nem começou ontem e nem termina hoje. Reformas sociais, em ambiente democrático são, por natureza, lentas e politicamente custosas. Mudanças rápidas são típicas de regimes autoritários.” 39

\section{Execução e controle}

O que importa salientar é que à ampliação de direitos consagrada em 1988 correspondeu um vastíssimo alargamento de mecanismos para a garantia desses direitos. Dentre tais mecanismos destacam-se as funções atribuídas ao Ministério Público, sem precedentes nas Constituições anteriores.

Na CF de 1969, o MP era tratado no título da Organização Nacional, no capítulo do Poder Executivo. À época comentava o Professor Vicente Greco Filho:

"(...) No plano institucional, difícil tem sido a perfeita definição da posição do Ministério Público. Em nossa história constitucional, já esteve ele dentro do capítulo do Poder Judiciário, já esteve em capítulo autônomo e atualmente, na Constituição Federal, encontra-se no capítulo do Poder Executivo, após as Forças Armadas e antes dos Funcionários Públicos." 40

Atualmente, a seção relativa ao Ministério Público está situada no título da Organização dos Poderes, no capítulo das Funções Essenciais à Justiça, sem qualquer subordinação aos Poderes Legislativo, Executivo ou Judiciário, tendo assegurada sua autonomia funcional e administrativa, incumbindo-lhe nada menos que a defesa da ordem jurídica, do regime democrático e dos interesses sociais e individuais indisponíveis (art. 127) . Assim comenta a mudança o Promotor de Justiça Ronaldo Porto Macedo Júnior:

"(...) A Constituição Federal de 1988 conferiu um novo perfil institucional ao Ministério

Idem, p.15. Grifos no original.

Idem, p.41.

9 MENDES, E. V., 1996, p.57.

40 GRECO F ${ }^{\circ}$, V., 1988, p.158. 
Público. A partir da própria análise do texto constitucional pode-se perceber que o promotor de justiça passou a definir-se como órgão agente em favor dos interesses sociais. Neste sentido, tornou-se uma espécie de 'ombudsman' não eleito da sociedade brasileira." $^{41}$

Tais modificações são indicadas apenas para efeito ilustrativo, e nem de longe representativo, da imensa gama de inovações conceituais trazidas com a Constituição para o interior do sistema jurídico. Dentre elas, a observância aos princípios e diretrizes norteadores do SUS, como universalidade e integralidade no atendimento, descentralização e participação da comunidade, ${ }^{42}$ são aspectos pelos quais o MP tem agora o dever constitucional de zelar em qualquer situação que tenha a saúde por objeto.

É preciso não esquecer que o SUS constitui o meio institucional de execução do direito à saúde, concebido como um dos três pilares da seguridade social, ao lado da previdência e da assistência social, e que a seguridade tem como um dos objetivos de sua organização o caráter democrático e descentralizado da gestão administrativa. ${ }^{43}$ Como já foi visto, desde a implantação da Lei Orgânica da Saúde (LOS), o sistema de saúde pode oferecer ao MP, "zelador" dos direitos constitucionais, todo um arsenal de recursos que em última análise lhe facilita cumprir, na área da saúde, mais uma atribuição constitucional que é a defesa da ordem democrática, incumbência continuamente apresentada como impraticável por falta de instrumentos jurídicos.

"Deve-se recordar que o mais forte argumento adotado pelos reacionários de todos os países contra os direitos do homem, particularmente contra os direitos sociais, não é a sua falta de fundamento, mas a sua inexeqüibilidade. Quando se trata de enunciá-los, o acordo é obtido com relativa facilidade, independentemente do maior ou menor poder de convicção de seu fundamento absoluto; quando se trata de passar à ação, ainda que o fundamento seja inquestionável, começam as reservas e as oposições." 44

Constituindo-se em meio institucional de controle sobre o efetivo respeito pelo direito à saúde, o Ministério Público deve assumir uma posição de onde possa confortavelmente observar seu equivalente de execução, o SUS. Sem este tipo de preocupação, o MP se verá praticamente desprovido de informações que operacionalizem sua função de zelo. Conhecer os graus dessa preocupação no cotidiano da instituição e seus efeitos sobre a eficácia da norma é o que justifica a análise aqui proposta.

41 MACEDO JR., R.P., 1995, p.45.

42 CF, arts. 196 e 198.

43 CF, art.194, § único, VII. 
A hipótese de existência de dificuldades no cumprimento dessa nova atribuição do MP surge do impacto que o advento dos direitos sociais tem causado na prática dos profissionais do direito, cuja formação predominantemente baseada no sistema normativo de inspiração liberal, voltado para a solução de conflitos interindividuais, indica para um possível desconforto em se lidar, no meio jurídico, com demandas de massa cujas soluções envolvem a implantação de políticas públicas.

A própria assunção de que pode haver tal desconforto permite antecipar uma segunda hipótese, que é a de haver graus diferenciados de familiaridade, senão de afinidade, quando o MP atua junto a instituições suas parceiras no sistema de justiça, pela proximidade natural entre profissionais de mesma formação, e quando atua junto a instituições outras. Isto pode representar um problema na medida em que a garantia dos direitos sociais depende da interlocução com formuladores de políticas públicas, o que faz pressupor a necessidade de o MP estender sua já tradicional desenvoltura no trato com o Judiciário aos outros dois Poderes e aos diversos segmentos da sociedade civil.

Ainda que estas hipóteses não se confirmem, ou seja, que a atuação do Ministério Público aponte para a completa adequação a seu novo perfil sem que ao final da pesquisa qualquer das supostas dificuldades seja identificada, ainda assim a verificação e análise propostas se justificam por registrar um modelo institucional passível de inspirar outros contextos em que os meios de controle sobre o direito à saúde não sejam plenamente eficazes.

"Do ponto de vista organizacional, trata-se de uma estrutura monocrática, sendo significativa a margem de liberdade de atuação de cada promotor ou procurador. Desta forma, pode ser considerável a distância entre um desempenho tipicamente conservador e outro que procure realizar ao máximo as possibilidades legais de presença da instituição. No que se refere ao grau de institucionalização, as modificações introduzidas pela Constituição Federal de 1988 e pelos textos legais do início dos anos 80 ao mesmo tempo que imprimiram mudanças significativas nas atribuições do Ministério Público, alterando o perfil clássico da instituição, tornaram menos claros os limites e a forma de ação de seus membros. O processo de construção de identidade da instituição, longe de definir-se como consolidado, encontra-se em aberto, dependendo, em boa medida, das características que seus integrantes imponham às suas ações. A combinação das atribuições e das garantias constitucionais, o tipo de organização e, paradoxalmente, o baixo grau de institucionalização, atuam como fatores que potencializam a capacidade de atuação do Ministério Público como um agente com capacidade de interferir de forma

44 BOBBIO, N., 1992, p.24. 
incisiva na promoção dos direitos da cidadania. A transformação da potencialidade em realidade dependerá de ações concretas, da forma como são entendidas e desempenhadas as atribuições legais. Conseqüentemente, torna-se imprescindível a análise de situações concretas, nas quais se possa examinar de que forma vem sendo construída a identidade institucional do Ministério Público e qual o grau de importância atribuído, nesta construção, à implementação dos direitos individuais e coletivos que compõem a cidadania." 45

É importante ressaltar que o estudo das instituições do sistema de justiça tem merecido atenção não apenas acadêmica, por parte de cientistas políticos, sociólogos, entre outros, mas começa também a despertar o interesse de diversos segmentos da sociedade civil. ${ }^{46}$

Note-se, inclusive, que a própria instituição que examinamos se dispõe a pesquisas do gênero, cujos primeiros resultados demonstram a pertinência do tema: os membros do Ministério Público estão convencidos de que a prestação da Justiça melhorou com as novas atribuições que lhes foram dadas pela Constituição de 1988, concordam com a crítica à má formação profissional e são a favor de que o Ministério Público seja o canal das demandas sociais. $^{47}$

45 SADEK, Maria Tereza. Apresentação de CAVALCANTI, Rosângela Batista. Cidadania e Acesso à Justiça: Promotorias de Justiça da Comunidade. São Paulo: IDESP, 1999, pp.10-11.

46 OPAS, 1998. Anais do IV Seminário Internacional de Direito Sanitário, em torno do tema Relações Público/Privado na Eficácia do Direito à Saúde, realizado em junho de 1996 na Faculdade de Saúde Pública da Universidade de São Paulo.

47 IDESP, 1996. 


\subsection{Enunciados}

Apresentados objeto, objetivos, procedimento metodológico e justificativa, ou seja, respondidas as questões relativas a o que, como e por quê estudar, passa-se a proceder ao estudo propriamente dito, a começar pelas implicações teóricas das noções que o embasam.

“Apesar das inúmeras tentativas de análise definitória, a linguagem dos direitos permanece bastante ambígua, pouco rigorosa e freqüentemente usada de modo retórico. Nada impede que se use o mesmo termo para indicar direitos apenas proclamados numa declaração, até mesmo solene, e direitos efetivamente protegidos num ordenamento jurídico inspirado nos princípios do constitucionalismo, onde haja juízes imparciais e várias formas de poder executivo das decisões dos juízes. Mas entre uns e outros há uma bela diferença!" 48

A explicitação, desde logo, de termos, linguagem, pressupostos, conceitos, concepções, periodizações e modelos adotados, em qualquer pesquisa científica, tem por propósito observar regras metodológicas. Neste trabalho, típico de sociologia jurídica, visa também evitar avaliação exclusivamente sob uma perspectiva dogmática do direito.

A sociologia do direito é disciplina de investigação eminentemente zetética, ou seja, conserva o caráter hipotético e problemático de suas premissas, ao contrário da investigação dogmática, em que impera a inegabilidade dos pontos de partida.

"Este questionamento aberto, que faz dos problemas zetéticos questões infinitas, não significa que não haja absolutamente pontos de partida estabelecidos de investigação. Isto é, não se quer dizer que algumas premissas não sejam, ainda que provisória e precariamente, postas fora de dúvida. Assim, por exemplo, uma sociologia do direito (zetética) parte da premissa de que o fenômeno jurídico é um fenômeno social. Isto, entretanto, não a confunde com uma investigação dogmática." 49

A utilização de terminologia adequada integra o referencial teórico que fundamenta toda pesquisa e determina o encaminhamento de outras questões de fundo que venham a surgir no decorrer do trabalho. Assim, torna-se indispensável apresentar o estado da arte na compreensão de designações cujo uso no "senso comum teórico dos juristas" 50 possa envolver pressupostos incompatíveis com o tratamento que se pretende dar a elas.

Para isto, destacam-se inicialmente os termos que compõem o objetivo aqui proposto, evitando-se possíveis equívocos quanto aos próprios elementos estruturais do trabalho:

48 BOBBIO, N., 1992, p.9.

49 FERRAZ JR., T.S., 1988, p. 43. Grifos no original. 
eficácia, função institucional e relevância pública. Outras expressões e conceitos terão suas implicações teóricas apreciadas conforme o desenvolvimento temático demande.

\section{Eficácia}

Parte-se de uma diferenciação já clássica entre validade e eficácia, em que a validade (ou vigência) é conceituada como a conformidade de uma norma com uma outra norma que lhe seja hierarquicamente superior, tomando por referência o próprio sistema normativo, enquanto a eficácia é conceituada como a efetiva aplicação e observação de uma norma no plano fático, tomando por referência efeitos verificados fora do sistema normativo.

Deste modo, o critério de validade está situado no plano do dever-ser, na medida em que uma norma é considerada válida se tiver sido produzida de acordo com o ordenamento, devendo ter sua origem remota na norma fundamental do sistema. Trata-se de critério basicamente formal e auto-referenciado, pelo qual a norma se caracteriza como jurídica a partir de uma perspectiva dogmática.

Por outro lado, a eficácia situa-se no plano do ser, da aplicação a casos concretos, na medida em que uma norma é considerada eficaz se produzir efeitos tanto no plano fático como no jurídico. ${ }^{51}$

É preciso ressaltar que, apesar de estarem situadas em mundos distintos, o do ser e o do dever-ser, a eficácia e a validade mantêm estreita conexão:

“(...) A eficácia é, nesta medida, condição da vigência, visto que ao estabelecimento de uma norma deve seguir a sua eficácia para que ela não perca a sua vigência. (...) Dizer que uma norma vale (é vigente) traduz algo diferente do que se diz quando se afirma que ela é efetivamente aplicada e respeitada, se bem que entre vigência e eficácia possa existir uma certa conexão. Uma norma jurídica é considerada como objetivamente válida apenas e quando a conduta humana que ela regula lhe corresponde efetivamente, pelo menos numa certa medida. Uma norma que nunca e em parte alguma é aplicada e respeitada, isto é, uma norma que - como costuma dizer-se - não é eficaz em uma certa medida, não será considerada como norma válida (vigente). Um mínimo de eficácia (como normalmente se diz) é a condição de sua vigência." 52

Pode-se afirmar que uma norma é eficaz a partir de dois enfoques: (a) será juridicamente eficaz se apresentar condições técnicas para ser aplicada e exigida dentro dos

50 WARAT, L.A., 1987.

51 Para uma precisa diferenciação dos termos validade, vigência, vigor e eficácia, FERRAZ JR., T.S., 1988, p.181.

52 KELSEN, H., 1985, pp.11-12. Original sem grifos. 
limites do sistema normativo, correspondendo esta eficácia jurídica à possibilidade de aplicação da norma, ou seja, à sua aplicabilidade; (b) será socialmente eficaz se apresentar "condições sócio-econômicas, políticas, culturais e ideológicas para seu reconhecimento, sua aceitação e seu cumprimento por parte de seus destinatários", correspondendo esta eficácia social à efetiva aplicação da norma a casos concretos. ${ }^{53}$

"Essa distinção conceitual é bastante esquemática. Longe de se excluírem, as definições 'jus-dogmática' e 'jus-sociológica' de eficácia são analiticamente ricas quando utilizadas em conjunto no exame de problemas concretos --- entre outros motivos porque, compreendida de modo exclusivista, a eficácia na perspectiva jus-dogmática subestima a diversidade e a complexidade das relações que os atores sociais mantêm com o direito; e, na perspectiva jus-sociológica, subestima os riscos de dissolução dos valores e procedimentos especificamente jurídicos numa dimensão utilitarista ou instrumental, por meio de variados mecanismos de violência simbólica. Nesse sentido, um determinado sistema jurídico não se torna eficaz apenas porque é um conjunto de regras internamente coerente, em termos lógico-formais, ou porque está sustentado no monopólio da força do poder que o positivou; ele também se torna eficaz porque os cidadãos incorporam suas consciências à premissa de que essas regras legais devem ser invioláveis. Sem a 'internalização' de um sentido 'genérico' de disciplina e sem o sistemático respeito às leis, aos códigos e às normas, a eficácia de uma ordem legal acabaria sendo seriamente comprometida, independentemente do poder repressivo do Estado que a impõe." 54

Precisamente o "sistemático respeito às leis, aos códigos e às normas" de direito à saúde é que constitui o objeto do zelo cuja eficácia este trabalho busca averiguar, o que faz esta investigação, portanto, ter seu eixo centralizado no modo como o sujeito destinatário da norma concebe esse objeto e se relaciona com ele. Ao confiar ao MP a função de garantir que um direito constitucional seja efetivamente respeitado, o art.129, II, nada mais fez que lhe atribuir a função de permanentemente avaliar e impulsionar esse respeito de fato, ou dito de outro modo, garantir que as normas relativas a tal direito sejam socialmente eficazes.

"Qual a utilidade, na área da saúde, de uma ordem jurídica válida, mas injusta ou ineficaz? Ou justa, mas inválida ou ineficaz? Ou ainda: eficaz, mas inválida e injusta. Em outras palavras, no campo do direito à saúde, como de resto em todo o vastíssimo espectro dos direitos sociais, os trinômios 'validade-justiça-eficácia' - 'norma-valor-fato' devem, necessariamente, instaurar um intercâmbio incessante entre seus elementos." 55

53 FARIA, J.E., 1993, p.96.

54 Idem, p.97.

55 CAMPILONGO, C.F., 1992, p.1. 
Assim, aplicando-se a dupla dimensão da eficácia, pode-se dizer que uma norma que carece de regulamentação para ser exigível é juridicamente ineficaz, mas será socialmente ineficaz, ainda que regulamentada, se carecer de condições de fato para ser observada.

“A assunção pelo texto constitucional dos resultados que se pretende alcançar com a implementação de políticas permite que se distingam algumas normas que têm o caráter de diretrizes para a atuação e interpretação do Direito. É importante afastar delas qualquer confusão com as chamadas normas programáticas, que têm permitido a alguns caracterizá-las como simples expedientes travestidos de normas, das quais não se espera algum efeito jurídico. As diretrizes constitucionais, que estabelecem obrigação de resultado, vinculam o aplicador ou intérprete, condicionando a legalidade da norma à submissão aos fins nelas declarados. Freqüentemente empregando conceitos abertos, especialmente porque devem ser aplicados a inúmeras situações de difícil determinação prévia, os termos que os expressam, conforme acolhidos na diretriz, exigem a consideração da realidade em que a norma será efetivada para sua precisão." 56

Com relação ao direito à saúde, essa discussão está prejudicada: desde a vigência da LOS, o estudo da eficácia do direito à saúde prescinde de uma análise sobre a aplicabilidade da norma que o declara, ou seja, sobre as condições técnico-jurídicas para ser aplicada, exigida e executada. Ainda que se pudesse identificar o direito à saúde como apenas mais um caso dentre os direitos sociais, freqüentemente declarados por normas programáticas, de eficácia limitada, parece já haver consenso em que a regulamentação dada pela LOS já supriu suficientemente qualquer impossibilidade formal de aplicação, exigibilidade e executoriedade. Resta avançar agora em relação à sua eficácia social, no sentido de mapear, a partir dos casos concretos, as condições sociológicas de aplicação da norma que regulamenta o direito à saúde.

"Como essa concepção jus-sociológica trata a eficácia jurídica a partir de uma dimensão eminentemente substantiva, ela torna possível (a) uma visão crítica dos objetivos originariamente previstos pelas normas e dos resultados por elas efetivamente gerados num determinado contexto sócio-político e (b) uma avaliação histórica da efetiva aplicação material das normas, tendo em vista a correspondência entre os fins estabelecidos pelo legislador e os valores culturais enraizados entre os diferentes destinatários das leis num determinado sistema social." 57

Justamente o que torna complexa a tarefa do Ministério Público de zelar pelo respeito às normas relativas ao direito à saúde é o fato deste se constituir num objeto, como já visto,

56 DALLARI, S.G., 1995, p.28. 
de conteúdo indeterminado, essência interdisciplinar e natureza situacional, fatores que condicionam a própria existência desse direito a uma contínua negociação em torno das políticas que o definem.

"A amplitude do conceito de saúde e sua abrangência como 'direito de todos e dever do Estado', isto é, como em 'direito subjetivo público que não pode ser negado a nenhuma pessoa, sob pretexto algum, não se coaduna com os indicadores sociais brasileiros e latino-americanos. A saúde é resultante das condições de habitação, alimentação e educação. No Brasil, temos $45 \%$ das moradias sem nenhuma infraestrutura, $64 \%$ da população estão desnutridos e menos de $50 \%$ das crianças que ingressam nas escolas chegam ao $2^{\circ}$ ano de estudos. Saúde é resultante, igualmente, das condições de renda, emprego e acesso à posse da terra. Mas o Brasil figura entre os exemplos mais perversos de concentração de renda em todo o mundo, com um salário mínimo em torno de US\$ 90, sendo que $82 \%$ dos brasileiros ganham de 0 a 3 salários mínimos. O número de desempregados nas cidades gira em torno de 15 milhões. A concentração latifundiária e o número de 'sem-terras' também são alarmantes. Como, diante dessa conjuntura, falar na saúde como direito de todos? Saúde como direito formal, despido das demais condições e, conseqüentemente, sem eficácia?" 58

Portanto, uma avaliação jus-sociológica, nos termos acima, sobre estar ou não sendo respeitado o direito à saúde, pressupõe que se conheçam tanto as metas fixadas no sistema local de saúde como os indicadores dos respectivos resultados. E também, entre metas e resultados, as condições fáticas de eficácia social da norma, pois, sem cotejá-la com os dados extrajurídicos que a cercam, estaria-se prescindindo dos próprios instrumentos que permitem não apenas parametrizar os graus de eficácia dessa norma, no sentido de ser mais ou menos respeitada, mas que permitem principalmente revelar as condições de seu reconhecimento conforme tenha melhor ou pior aplicação. Para isso, no caso específico do direito à saúde, conta o MP com canais de captação de demandas e avaliação de políticas já institucionalizados em órgãos colegiados de participação popular, cuja eficácia, ipso facto, também constitui objeto de sua tutela:

"Na realidade, o sucesso de qualquer política governamental depende tanto de sua qualidade técnica quanto da adequação entre suas expectativas sociais implícitas e a efetiva distribuição de valores e atitudes, e suas respectivas intensidades, pela população. Uma política tão trivial quanto uma campanha de vacinação nada significa se não contar com a adesão subjetiva de pais e mães à premissa governamental de que é valioso e

57 FARIA, J.E., 1993, p.97.

58 CAMPILONGO, C.F., 1992, p.3 
racional absorver custos de tempo e desconforto tendo em vista a probabilidade de benefício futuro esperado.

Generalizando, a eficácia das políticas governamentais encontra-se em estrita dependência do estado da cultura cívica do país, prevalecente em cada conjuntura histórica. (....) Por cultura cívica entende-se aqui, classicamente, o sistema de crenças compartilhado pela população quanto aos poderes públicos, quanto à própria sociedade em que vive, e quanto ao catálogo de direitos e deveres que cada qual acredita ser o seu. (....) Uma cultura cívica predatória é o que se pode esperar quando a população é composta por indivíduos que se consideram um ao outro: destruidor, acomodado, esperto, mal-educado, irresponsável, preguiçoso, impaciente e desonesto (pesquisa da Soma, Opinião e Mercado, em Isto É / Senhor, 27/3/91). (....) É nesta sociedade de predadores que se discutem hoje modelos de representação para melhor garantir eficácia governamental e crescente bem-estar da cidadania." 59

Exatamente porque será necessário garantir a efetiva participação da comunidade como diretriz do sistema de saúde (CF, art.198) é que o tema da representação política passa a ser crucial na compreensão do novo papel do Ministério Público. Basta lembrar que a habilitação ao SUS exige que os entes políticos comprovem a implementação de todos os instrumentos fixados na Lei Orgânica da Saúde, sujeitos ao controle popular: Conferências de Saúde; Conselhos de Saúde; Fundo de Saúde; Relatórios de Gestão e contrapartida de recursos no respectivo orçamento. ${ }^{60}$

"(....) a crise dos modelos jurídico-dogmáticos fez com que os juristas entrassem em 'órbita' ao tratar da teoria da representação política. Não é difícil compreender o porque. A representação política ocupa lugar central na teoria constitucional. A Carga Magna, em termos funcionais, promove o 'acoplamento estrutural' entre os sistemas jurídico e político.

59 SANTOS, W.G., 1993, pp.104-105.

${ }^{60} \operatorname{LOS} 8.142 / 90$, arts. $1^{\circ} \mathrm{e} 4^{\circ}$. 
Como, então, compreender a representação política? Trata-se de um instituto jurídico ou político? Ou, ao contrário, a representação desempenha funções e prestações comuns aos dois sistemas?

Responder a esses quesitos não é simples. Por isso os juristas 'entram em órbita' ao enfrentá-los. Os sistemas jurídico e político podem ser descritos, como faz Luhmann figurativamente, como duas bolas de bilhar. Uma não se confunde com a outra. Porém, o jogo só tem sentido quando as duas bolas se tocam. AConstituição e as instituições representativas operam exatamente nesse ponto de contato. As duas 'bolas' sugerem, de uma parte, a separação funcional dos sistemas e, da outra, um conjunto de prestações recíprocas entre a política e o direito. Só nesse sentido um sistema depende do outro. (....) Em resumo: a função do sistema político - tomar decisões coletivas - não se confunde com a do sistema jurídico - garantir direitos. Apesar dessa diferenciação, o sistema político fornece ao sistema jurídico prestações fundamentais, vale dizer, as premissas decisórias (leis) e o reforço da eficácia das decisões jurídicas (polícia, prisões, enfim, os meios coercitivos). Igualmente relevantes são as prestações dadas no sentido inverso, isto é, do sistema jurídico ao sistema político, na forma de legitimação das decisões políticas (aplicação das leis) e de oferecimento das premissas para o uso da violência (regulação jurídica do monopólio estatal da força). Por isso, apesar de paradoxal, quanto maior a independência de um sistema, maior também a dependência em relação ao outro." 61

Ainda que situado no interior do sistema de justiça, o Ministério Público teve em suas novas atribuições um veículo de migração para a periferia do sistema, expondo-se mais e mais à interface com decisões de natureza diversa daquelas emanadas pelo Judiciário. Esta certamente é uma posição que lhe permite selecionar as demandas a serem encaminhadas, ou não, à última instância, segundo critérios jurídicos de filtragem, numa atuação mais tradicional porque voltada para o centro do sistema jurídico. Ao lidar com demandas que necessariamente envolvem decisões políticas, como é o caso das deliberações estratégicas originadas em conselhos de saúde, sua função passa a ser informada por critérios que garantam a viabilidade mesma das decisões tomadas por instituições não integrantes do sistema de justiça, numa atuação mais voltada para o exterior desse sistema.

"A representação expõe constantemente os temas da política aos riscos do consenso e do dissenso. O povo é 'admirável para escolher', dizia Montesquieu. Escolher significa tornar viável não só o governo, mas também a oposição e a possibilidade de que a oposição vire governo e vice-versa. A democracia vive dessa constante instabilidade, da plausibilidade 
de que as escolhas sejam sempre diversas, seqüenciais e reversíveis. Por isso - como afirma Raffaele De Giorgi - a democracia se ajusta, melhor do que qualquer outra fórmula de governo, a manter sempre elevado o nível da complexidade social e abertas as possibilidades de escolha. Ao Poder Judiciário, no desempenho de sua função infungível e no operar do seu código específico, recai a responsabilidade pela garantia dos direitos das minorias e das oposições. (....) É nesse pano de fundo que ressurge o debate sobre a expansão da função política dos tribunais, do Ministério Público e dos operadores jurídicos em geral; a chamada 'politização do Judiciário'. O outro lado da medalha vem representado por um processo de substituição e delegação do sistema político para o sistema jurídico (e, no seu interior, particularmente os tribunais) de importantes competências decisórias: a suposta 'judicialização da política'." ${ }^{62}$

\section{Função institucional}

Muito embora se pudesse interpretar amplamente a inserção do Ministério Público em capítulo constitucional intitulado Das funções Essenciais à Justiça, a própria redação do art.127 parece restringir a noção de justiça à atividade jurisdicional:

“O Ministério Público é instituição permanente, essencial à função jurisdicional do Estado, incumbindo-lhe a defesa da ordem jurídica, do regime democrático e dos interesses sociais e individuais indisponíveis."

Não bastasse a Constituição Federal afirmá-lo, esse texto encontra-se transcrito literalmente em todas as Leis Orgânicas do MP, a Nacional, a Federal e a Estadual. ${ }^{63}$

Se a própria existência das funções essenciais à justiça, "compostas por todas aquelas atividades profissionais públicas ou privadas, sem as quais o Poder Judiciário não pode funcionar ou funcionará muito mal", e que são "procuratórias e propulsoras da atividade jurisdicional” - ${ }^{64}$ está assim fundamentada no princípio da inércia do Judiciário, a questão está em saber se tal justificativa é limitadora da atuação de tais instituições, no sentido de serem atuantes exclusivamente em função dele.

As atuais atribuições do Ministério Público fornecem elementos que permitem caracterizá-lo como serviço legal ao mesmo tempo tradicional e inovador: "a primeira grande

1 CAMPILONGO, C.F., 1996, pp.53-54.

62 Idem, p.55-56.

63 LOMP, art. $1^{\circ}$, LOMPU, art. $1^{\circ}$, LOEMP/SP, art. $1^{\circ}$.

64 SILVA, J.A., 1992, p.506. 
distinção associa os serviços legais tradicionais ao atendimento individualizado e os serviços legais inovadores aos casos de interesse coletivo." Enquanto o modelo tradicional de serviços legais "pressupõe uma relação hierarquizada entre advogados e clientes", os serviços legais inovadores os nivela: mesmo um bacharel se coloca como "um dentre os participantes de uma luta ou postulação jurídica que beneficiará toda a comunidade. Confere a seu conhecimento profissional uma função social que suplanta a harmonização ou solução de litígios individuais. (....) Equipes compostas por advogados e profissionais de outras áreas demonstram que o direito não é o principal nem o menos relevante dos mecanismos de mudança social, mas apenas um dos muitos instrumentos de ação transformadora. Em verdade, a perspectiva multidisciplinar tende a resgatar ao direito e aos advogados funções até então encobertas ou desconhecidas pelos próprios juristas." ${ }^{65}$

Não é difícil perceber que um dos problemas que se colocam atualmente para o MP como serviço legal inovador é detectar e sanar as causas para --- mesmo depois de uma década sob a nova Constituição --- ainda não ser possível ver garantidos direitos básicos como o direito à saúde, já suficientemente regulamentado há mais de oito anos.

Diante da pluralidade dos interesses e da impossibilidade de um valor totalizante, ainda que o direito expresse a maioria representada, não atinge a todos a que se destina. No limite, o próprio sistema exclui uma parcela da população, disfunção que tem se revelado majoritária.

Assim, a idéia por si só de o Ministério Público servir como canal mediador para solução das demandas sociais parece firmar seu papel político na aproximação da sociedade junto ao órgão jurisdicional do Estado: apesar de diversos entes representativos da sociedade estarem legitimados a promoverem ações judiciais cabíveis para a proteção de interesses difusos e coletivos, o MP é

"hoje autor de $96 \%$ de todas as ações civis públicas ambientais em trâmite pelos tribunais do país. A despeito da ausência de dados estatísticos precisos, é válido supor que tal situação de quase monopólio de fato (de vez que o Ministério Público não tem o monopólio jurídico para a propositura dessas ações) também se estende às ações civis em defesa dos demais interesses sociais coletivos ou difusos." 66

Tais indicadores levam a crer que outros co-legitimados para tal proteção deixaram de fazê-lo, preferindo representar junto ao MP. Deste modo, enquanto a sociedade continua

65 Conforme tipologias utilizadas em FALCÃO, J.A., 1989 e CAMPILONGO, C.F., 1991.

66 MILARÉ, Edis. "O Ministério Público e a defesa do meio ambiente." Texto aprovado na reunião de curadores de meio ambiente do Brasil, 1992, mimeo, apud MACEDO JR., R.P., 1995, p.42. 
aguardando ser tutelada por iniciativa do Estado, despreza ou desconhece - de qualquer modo ignora - o instrumental para participar do espaço decisório representado pelo Judiciário.

O resultado é que o MP se depara com uma demanda complexa e especializada que se mantém crescente, em que pese a baixa credibilidade nos canais judiciários: pesquisa IBGE indica que entre 1983 e 1988, 67\% das pessoas que admitiram ter estado envolvidas em conflitos optaram por resolvê-los via extrajudicial; ainda que distante no tempo, este dado evidencia quão tímida é a provocação do Judiciário se considerada toda a população, tendência dificilmente reversível a médio prazo. ${ }^{67}$

Por sua vez, ainda não provocado o suficiente com relação aos novos direitos, e portanto não fortalecido a ponto de exercer influência na implantação de políticas públicas, o Judiciário gera decisões por vezes desprovidas de alcance suficiente, uma vez que as condições reais para sua execução distam demais das condições pressupostas pelo modelo jurídico tradicional. Desacreditado por conta da lentidão e desse distanciamento em relação aos direitos sociais, sendo frequientemente utilizado como simples instrumento de pressão nas negociações de interesses, o Judiciário perde espaço decisório para outras esferas em que a negociação constitui o único meio de atingir algum consenso em torno das prioridades.

Esta dupla realidade - o inchaço das demandas junto ao MP e o esvaziamento do Poder Judiciário como esfera decisória - parece ter efeitos decisivos sobre a eficácia social das normas. Aqui se torna nítida a relevância de um canal institucionalizado não apenas para a defesa judicial dos interesses coletivos, mas também e principalmente para a promoção de um fortalecimento da cidadania. De fato, apenas por meio de insistente provocação por parte da sociedade é que o Estado, por suas instituições jurídicas, terá condições de oferecer respostas aos novos conflitos não necessariamente duais, aproximando-se das discussões que se travam à sua margem, inserindo-se novamente na realidade que o cerca e, finalmente, dotando as decisões judiciais de uma função efetivamente garantidora de direitos.

"O Judiciário, provocado adequadamente, pode ser um instrumento de formação de políticas públicas. Exemplo disto certamente é o caso da previdência social brasileira. Não fosse a atitude dos cidadãos de reivindicarem judicialmente e em massa seus interesses ou direitos, ficaríamos mais ou menos onde sempre estivemos. Mas aqui, também, o Judiciário há de dividir o papel de protagonista dos casos com os cidadãos e advogados iniciadores das ações. Resta ver, para que efetivamente se fale em políticas públicas, que haja iniciativas de caráter menos particularmente reivindicantes e mais

67 FIBGE. Participação político-social - 1988. Vol I, Justiça e vitimização. Rio de Janeiro, 1990, apud SANTOS, W.G., 1993. 
sociais, como nas defesas de interesses difusos antes que de interesses individuais homogêneos, conforme se diz na moderna processualística. (...) Pela sua natureza, o debate judicial permite o avanço da democracia ao permitir as discussões de temas relevantes. Seja lá qual for a nossa opinião a respeito de temas como censura, liberdade de imprensa, aborto, direitos de minorias, direito de greve etc., sua submissão a uma discussão judicial amplia o espaço da democracia, porque exige, com mais ou menos sucesso, a racionalidade das propostas divergentes." 68

Boaventura de Sousa Santos apresenta a democratização da administração da justiça por duas vertentes:

(a) constituição interna do processo (maior envolvimento e participação dos cidadãos, simplificação dos atos processuais, ampliação dos conceitos de legitimidade e interesse de agir etc) e

(b) democratização do acesso à justiça, na tentativa não apenas de eliminar diferenças econômicas, mas sociais e culturais, por meio de ações educativas, esclarecedoras de direitos.

Entretanto, aponta para limites de tal democratização:

"a desigualdade da proteção dos interesses sociais dos diferentes grupos sociais está cristalizada no próprio direito substantivo pelo que a democratização da administração da justiça mesmo se plenamente realizada não conseguirá mais do que igualizar os mecanismos de desigualdade. Há pouco um jurista chileno dizia que não fazia sentido lutar no seu país pelo acesso à justiça por parte das classes populares já que o direito substantivo era tão discriminatório em relação a elas que a atitude política democrática consistia exatamente em minimizar o acesso. (...) quanto mais caracterizadamente uma lei protege os interesses populares e emergentes maior é a probabilidade de que ela não seja aplicada”. 69

Mesmo contando com novos instrumentos processuais que permitem defender direitos coletivos em juízo, é preciso lembrar, com Boaventura Santos, que a democratização do acesso à justiça depende de fatores sociais, econômicos e culturais. Não apenas a democratização do acesso à justiça, mas o próprio direito, especialmente o direito à saúde, 
cuja eficácia é declaradamente condicionada a políticas de natureza social e econômica. Ainda que o membro do MP tenha envolvimento político e convicções políticas coincidentes com o direito que defende, esta não é uma característica definidora do trabalho que desenvolve. No entanto, a exigibilidade de observância aos canais democráticos de fixação de estratégias políticas é condição absolutamente necessária para que a tutela desse direito se complete.

Evidentemente, medidas de largo alcance envolvendo políticas públicas de cunho social, econômico, político, que redundem em resultados visíveis a longo prazo constituem talvez o instrumento mais eficaz na solução dos problemas em foco.

Entretanto, reconhecer que a solução depende das políticas públicas não significa reconhecer que isto é suficiente, mesmo porque tais políticas estão cercadas de condicionantes, a saber:

- a formulação de políticas pressupõe conhecimento dos fatores determinantes das situações indesejadas. Nem sempre estes fatores são evidentes e nem sempre quem os conhece é consultado por quem elabora o planejamento de ação, o que gera o risco de se combaterem apenas os efeitos, não as causas;

- para que tais políticas atinjam objetivos bem definidos é preciso que haja uma coerência macroestratégica entre todos os setores envolvidos, o que demanda consenso em torno de prioridades mínimas. Este é um requisito de difícil aferição e seus efeitos só se verificam a longo prazo;

- a competência do Estado para implementar tais políticas (inclusive porque implicam abrangências fora do alcance de outras entidades) serve como um argumento muito cômodo para que imediatamente a relação Estado-sociedade perca seu vínculo.

Quanto a este último aspecto, é bom lembrar que não à toa a saúde integra a seguridade social, compreendida por ações de iniciativa não só dos Poderes Públicos, mas também da sociedade (CF, art.194). É evidente que há competências inerentes ao Estado, que demandam planejamentos mínimos para garantir efeitos de abrangência global, não pontuais. Cabe à sociedade evitar que problemas emergentes assumam dimensões tão amplas que inviabilizem qualquer definição que se possa esperar do Estado: o desafio já está dado por situações consolidadas de miséria e violência, e mesmo assim, a mais ágil e eficaz política pública estará sempre defasada em relação à velocidade com que tais situações se reproduzem.

“Os brasileiros vivem simultaneamente duas experiências difíceis: aprender a democracia e aprender as formas de democracia contemporâneas. Os setores sociais interessados na saúde buscavam, já no período pré-constituinte (especialmente a partir de 1985) a 
afirmação da saúde como um direito e o reconhecimento da necessária ampliação das formas de participação popular. E a Carta de 1988, declarando a constituição do Estado Democrático de Direito, reforçou a busca do ideal democrático por cidadãos atentos à coisa pública, que podem se manter informados e participar das políticas públicas. Deixando clara, também, a necessidade de participação da comunidade nas ações e serviços públicos de saúde (C.F. art.198, III).

Assim, o termo "advogar", tradicionalmente usado apenas para designar a atividade profissional do bacharel em direito regularmente licenciado, passa, também, a conformar uma nova expressão: a "advocacia em saúde", significando a reivindicação pelo direito à saúde.

O termo advocacia, assim utilizado, tem sua origem no inglês "advocacy". Nascido das experiências da democracia americana, que historicamente desenvolveram comportamentos de reivindicações de direito de modo característico e próprio, tem o significado de ações individuais e de grupos organizados que procuram influir sobre as autoridades e os particulares para que fiquem mais sensíveis às carências e necessidades diversas que emergem na sociedade." 70

Não se deve imaginar, no entanto, que a advocacia lato sensu possa prescindir da advocacia tradicional; se assim o fizesse, estaria perdendo a oportunidade de criar precedentes em casos exemplares. Aliás, um efeito paralelo é que quanto mais ações dessa natureza são ajuizadas, maior necessidade sentem os operadores do direito (juízes, promotores, delegados, advogados) de aprofundarem seu entendimento a respeito dos direitos sociais. Conseqüentemente, decisões mais esclarecidas vão aos poucos preenchendo de significado concreto a vaga noção de direito à saúde, o que só pode favorecer o ambiente em que atua o advogado em saúde, dentro ou fora dos tribunais.

Quando se parte dessa dimensão ampliada de advocacia, pressupõe-se um trabalho de educação. Como a advocacia em saúde não formula reivindicações genéricas, mas invariavelmente voltadas para a solução de um problema específico, é preciso que o potencial "cliente" saiba definir sua demanda com conhecimento dos fatores que a condicionam. Supondo que em determinada região a causa de problemas de saúde em crianças foi associada à falta de amamentação - situação não propriamente hipotética -, uma estratégia montada para criar condições objetivas de amamentação no local de trabalho da mulher, por exemplo, levaria

70 DALLARI, S.G. et al, 1996. 
a resultados mais eficazes que a mera distribuição gratuita de leite em pó, medida que seria inadequada ao caso. Mas não é ao advogado em saúde que cabe priorizar este ou aquele problema: a reivindicação será aquela formulada pelo cidadão, não pelo serviço legal que lhe é prestado. A participação do advogado se dá num segundo momento, após a escolha pela solução de um problema e não de outro. Caso contrário, restaria desvirtuada a concepção de advocacia em saúde, que tem como um de seus pressupostos a participação do beneficiário, numa relação de igualdade para com o advogado.

Não é função, nem deve ser objetivo de quem pretende advogar em saúde "inventar" uma causa. Esta postura ensejaria paternalismo, na melhor das hipóteses, e, na pior, oportunismos de interesses estranhos ao direito à saúde, sempre em nome dos menos privilegiados. Talvez a única reivindicação que um advogado em saúde possa eticamente promover em benefício de um cidadão sem um mínimo de informação sanitária seja o acesso a serviços de educação em saúde.

As tarefas não se confundem: o educador prepara para a cidadania, o advogado promove o exercício da cidadania. Em outras palavras, a educação em saúde é condição absolutamente necessária para que a advocacia em saúde se manifeste. Essa relação de dependência que a advocacia em saúde guarda com a educação é que, curiosamente, torna possível ao cidadão se emancipar: à medida em que reconhece seus problemas e pleiteia solução para eles, vai se tornando seu próprio advogado.

"Partindo do conceito de advocacia em saúde, podemos considerar que qualquer indivíduo é um potencial advogado. $\mathrm{O}$ advogado pode ter uma formação técnica ou ser leigo, pode agir individual ou coletivamente, pode, ainda, necessitar ou não de uma assistência técnica. Dependendo de cada situação, tanto o perfil do advogado quanto a forma de advocacia em saúde vão sendo delineados de acordo com a intencionalidade do indivíduo. Isto se torna claro ao tomarmos o papel de um técnico que durante o seu trabalho pode ter em mãos dados ou informações capazes de causar mudanças nas condições de saúde da população. O técnico assume o papel de advogado quando decide tomar uma atitude que passa da esfera técnica para a esfera política. Esta atitude pode ser desde um alerta à população até a participação no processo de mudança do sistema ou de uma situação particular.

(....) As estratégias utilizadas pelas organizações-não-governamentais - ONGs - são exemplos paradigmáticos do papel de advogado.

(....) Não resta dúvida de que para o alcance do direito à saúde a ação dos Poderes Públicos é fundamental. Por isso, são nas instituições do Estado que desembocam as ações do advogado. O Executivo, Legislativo e o Judiciário possuem tarefas específicas, 
cabendo ao advogado em saúde, portanto, recorrer a estratégias distintas em cada âmbito. As especificidades, as lacunas, as normas que regem cada Poder deverão ser meticulosamente estudadas para a elaboração das estratégias de advocacia em saúde.

(....) É ainda no campo legislativo que a sociedade civil tem direito de opinar a respeito de algum projeto de lei, por meio das audiências públicas (C.F., art. 58, parágrafo 2o, II) e também de referendar as leis aprovadas (C.F., art.14, II)" ${ }^{71}$

É importante notar que o fato de o direito à saúde já contar com seus próprios canais de execução e controle não impede que um advogado em saúde, dentro da concepção apresentada acima, busque o aprimoramento do direito por meio da produção legislativa. No caso do MP, o zelo deve ser exercido sobre todos os Poderes Públicos, o que inclui o Legislativo, cuja forma de respeitar os direitos constitucionais é justamente adequando as normas infraconstitucionais que os tornem efetivamente viáveis.

Como foi citado acima, o sistema de saúde tem sofrido duras críticas e não faltam propostas para alterá-lo, ou mesmo eliminá-lo. Talvez atualmente o objeto de maior relevância para quem pretenda advogar saúde seja a garantia institucional do SUS, sejam quais forem as adaptações necessárias. Cuida-se de não permitir que o desmonte do meio atinja a finalidade do próprio direito. Não seria a primeira vez que vivenciamos esse paradoxo:

“A prisão a um líder político ou de um sindicalista, ou a repressão a um movimento comunitário quase nunca são atos restritos a conflitos localizados. Por isto mesmo, quase nunca puderam ser resolvidos através da defesa legal individualizada ou municipalizada. Esta tensão entre o individual e o coletivo, o local e o nacional assume diversas formas (...) Não raramente, no Brasil e em vários países da América Latina - excetuando os casos de tortura, desaparecimentos e assassinatos -, a violação dos direitos humanos foi violação legalizada. Quer dizer, a cassação dos direitos políticos, a impossibilidade de julgamentos imparciais, o cerceamento do direito de defesa, a violação dos direitos fundamentais dos trabalhadores deu-se quase sempre com base na lei. Com base na lei autoritária, é verdade. Mas, indubitavelmente, com base na lei estatal. Nestes casos, as organizações de serviços legais não podem buscar a mera aplicação e implementação da lei. Paradoxalmente, aplicar a lei é agravar a violação dos direitos humanos. Ao contrário, tem que buscar, quase sempre, a mudança da lei e do regime político que a produz. Revogar a lei e mudar o regime são tarefas coletivas e nacionais. Exige decisão do Legislativo, quase nunca do Legislativo local. Do Legislativo nacional. (...) Tudo produz situação aparentemente contraditória e paradoxal. Adefesa 
dos direitos se transforma na defesa contra a lei. E não na defesa através e a favor da lei. O jurídico é contra o legal. Daí a paradoxal e fundamental indagação: como utilizar a legislação para defender os cidadãos nos casos de violações individuais e localizadas, e ao mesmo tempo contribuir e pressionar para mudar nacionalmente a legislação?" 72

Relatos como estes demonstram a insuficiência dos serviços legais, durante os anos de repressão política, para zelar por direitos cuja efetividade exigia medidas extrajudiciais, dada a inadequação da defesa individualizada de direitos violados coletivamente, ou dito de outro modo, direitos cuja proteção exigia atuação coletiva e nacional, por vezes até internacional. ${ }^{73}$

Isto nos permite traçar um paralelo com dificuldades semelhantes encontradas atualmente para proteger direitos cuja eficácia dependa de políticas públicas:

"a prestação do serviço depende da real existência dos meios: não existindo escolas, hospitais e servidores capazes e em número suficiente para prestar o serviço, o que fazer? Prestá-lo a quem tiver tido a oportunidade e a sorte de obter uma decisão judicial e abandonar a imensa maioria à fila de espera? Seria isto viável de fato e de direito, se o serviço público deve pautar-se pela sua universalidade, impessoalidade e pelo atendimento a quem dele mais precisar e cronologicamente anteceder os outros? Começam, pois, a surgir dificuldades enormes quando se trata de defender com instrumentos individuais um direito social." 74

Esta reflexão busca orientar um entendimento sobre o quanto os obstáculos com que se deparam hoje os serviços legais são determinados por limites impostos pela tradição. Sem se ater a fatos, este enfoque procura evitar conclusões falhas por desconhecimento desses limites. Acredita-se que uma abordagem como esta possa contribuir no sentido de identificar dificuldades semelhantes no passado da instituição, assim como as formas então utilizadas para contorná-las, de modo a inspirar soluções que lhe resgatem o papel político, que agora lhe é atribuído constitucionalmente.

${ }^{71}$ DALLARI, S.G. et al., 1996.

72 Vide comentário do Professor Raffaele De Giorgi sobre ingenuidade de se pensar em direito universal à saúde sem possibilidade de ação judicial que o garanta, na medida em que um universalismo abstrato cristaliza diferenças. Anais do IV Seminário Internacional de Direito Sanitário, Faculdade de Saúde Pública/USP, S.Paulo, 1996. In: OPAS, 1998.

73 FALCÃO, J.A., 1989, p.147.

74 LOPES, J.R.L., 1994 (b), p.564. 


\section{Relevância pública}

Outro conceito que merece atenção é não apenas novo no direito positivo, mas central nas normas cuja eficácia se pretende pesquisar (art.129, II, combinado com art.197): trata-se do conceito constitucional de relevância pública.

Expressamente declarados de relevância pública pela Constituição Federal de 1988, as ações e serviços de saúde escapam à discussão sobre critérios diferenciadores na identificação de outros serviços potencialmente dotados de tal atribuição, que sejam passíveis de reconhecimento expresso pela lei infra-constitucional.

No entanto, alguns argumentos colhidos dessa discussão são úteis para ampliar o entendimento sobre a implicação prática de se declarar um serviço de relevância pública, e a partir daí dimensionar a função de zelo atribuída ao Ministério Público atrelada às ações e serviços de saúde.

Parece não haver outra conseqüência jurídica do reconhecimento da relevância pública que não seja a inclusão no rol de serviços cujo respeito aos direitos constitucionais será zelado pelo MP. A esse respeito observa o Professor Eros Grau que o fato de os serviços de saúde serem definidos constitucionalmente como sendo de relevância pública

"apenas os inclui entre aqueles considerados pelo preceito inserido no artigo 129, II, da Constituição; nada mais. (...) No caso, dizendo da relevância dos serviços de saúde, a Constituição findou por não lhe atribuir qualquer relevância especial.” 75

Seguindo este raciocínio, pode-se afirmar que o disposto pelo art.129, II, se aplica a qualquer serviço de relevância pública, não importa que tenha sido assim reconhecido pela Constituição ou por lei infra-constitucional, o que leva à conclusão de que os serviços de saúde têm apenas uma vantagem sobre os outros: foram reconhecidos desde logo.

No entanto, a mesma discussão enseja interpretação diversa, com base em que

"algo pode ser relevante sem ser principiológico, mas, com certeza, tudo o que é principiológico é relevante". 76

Assim, fundamentos como cidadania e dignidade da pessoa humana (CF,art. $\left.1^{\circ}, \mathrm{II}, \mathrm{III}\right)$ e objetivos de construir uma sociedade livre, justa e solidária, garantir o desenvolvimento

75 GRAU, Eros Roberto. "O conceito constitucional de relevância pública". In: CEPEDISA, 1992, p.22.

76 ARAUJO, Luiz Alberto David. "O conceito de 'relevância pública' na Constituição Federal de 1988". In: CEPEDISA, 1992, pp.26-27. 
nacional, erradicar a pobreza e a marginalização, reduzir as desigualdades sociais e regionais, promover o bem de todos, sem discriminação (CF, art.3ํ) são apresentados como princípios que informam direitos, inclusive o direito à saúde, levando a concluir que todo serviço voltado ao cumprimento de princípios constitucionais é dotado de relevância pública. Apenas no caso do art.197 o que há é manifestação inequívoca daqueles princípios localizada no contexto específico da saúde.

Neste caso, nem seria necessário declarar tal relevância, e nisto há um ponto de contato com a opinião do Professor Grau, quando nega utilidade ao reconhecimento expresso. A diferença está em que, partindo-se desta perspectiva, não há que se falar nem mesmo em reconhecimento infra-constitucional, uma vez que a relevância pública decorre diretamente dos princípios e que seu reconhecimento não depende da explicitação legal (note-se que o art.129, II, não condiciona o zelo em relação aos serviços de relevância pública conforme estejam ou não declarados em lei).

Até por uma questão de economia legislativa, parece absurdo exigir que serviços de inegável relevância pública - como são os serviços de educação, saúde, segurança e transporte, apenas para citar os exemplos mais evidentes - sejam formalmente declarados como tal para que deles se ocupe o Ministério Público no cumprimento de sua nova atribuição. Serviços dessa natureza são formas de consecução dos princípios constitucionais, de modo que negar sua relevância pública significaria emendar os próprios princípios. No limite, esse raciocínio permitiria equiparar os serviços de relevância pública aos princípios que os norteiam (ainda que esses serviços não estivessem assim declarados formalmente), uma vez que integram o núcleo material do sistema.

De qualquer modo, se às ações e serviços de saúde foi originariamente atribuído o caráter de relevância pública na Constituição, quem quer que pretenda alterar esse quadro há de enfrentar processo legislativo muito mais rígido que aquele demandado por uma norma infra-constitucional. Isto por si só reflete maior proteção. Apenas a título ilustrativo, uma figura possivelmente análoga seria a da imunidade tributária, que, comparada à isenção tributária concedida por lei, também representa um privilégio constitucional, chegando mesmo a ser tratado como princípio constitucional da tributação, ao lado de princípios gerais, especiais e específicos, na classificação de renomado constitucionalista. ${ }^{77}$

Talvez esta conclusão seja mais um discurso retórico previsto pelo Professor Grau como única conseqüência decorrente do predicado axiológico presente no art. 197 da Constituição,

77 SILVA, J.A., 1992, p.602. 
mas, neste trabalho, os subsídios oferecidos por esse discurso refletem diretamente sobre o objeto de estudo, fornecendo parâmetros que permitirão dimensionar o zelo dispensado pelo Ministério Público em relação aos direitos constitucionais, na forma do art.129, II.

Uma vez obtida a informação sobre quais serviços têm sido alvo de atuação para os efeitos dessa norma, alcança-se o entendimento sobre quais critérios contribuem para diferenciá-los de outros que não sejam de relevância pública, para além do critério formal (o reconhecimento explícito das ações e serviços de saúde).

Supõe-se que essa diferenciação revele o direcionamento institucional dado pelo MP à questão, possibilitando mapear a atuação na área de tutela dos direitos constitucionais e identificar como o direito à saúde se insere neste cenário. 


\section{COLETA DE DADOS}

Este capítulo se destina a descrever como foi executada esta fase da pesquisa e a relatar algumas observações feitas durante a obtenção dos dados, apresentando os resultados, independentemente da análise de seu conteúdo, que será desenvolvida na etapa seguinte.

Sem descuidar da abordagem global do MP, os resultados obtidos junto ao MPF e ao MPE serão tratados separadamente neste trabalho, em função das diferenças --- até mesmo estruturais --- possivelmente condicionantes da atuação de um e outro, a serem cotejadas oportunamente.

Os dados foram coletados por meio de duas técnicas diversas: levantamento documental e entrevistas.

\subsection{Levantamento documental}

No levantamento documental foram incluídos os dados institucionais: atos normativos, organogramas, relatórios de atividades, anais de encontros, propostas de gestão e outros documentos que pudessem refletir os aspectos estruturais e funcionais da instituição (i.e. sua forma de organização e distribuição interna de competências e estabelecimento de prioridades e diretrizes para o cumprimento de suas funções).

Também foram considerados documentos os procedimentos instalados como atividade-fim pelos membros do MP a partir de representações ou por iniciativa própria, de ofício, aqui designados simplesmente por demandas.

\section{Dados institucionais}

Os documentos descritivos da estrutura e funcionamento do MP constituíram instrumento valiosíssimo à pesquisa. Primeiro, por indicarem quais as instâncias apropriadas para perseguir os dados de forma sistemática, permitindo assim realizar o levantamento das demandas junto aos órgãos mais indicados e identificar os informantes que poderiam fornecer as declarações mais relevantes para o estudo. Segundo, por oferecerem um referencial para avaliar a atuação segundo os critérios da própria instituição.

Evidentemente, a própria legislação que organiza o MP foi a fonte primeira para a localização adequada dos órgãos institucionais junto aos quais as demandas de interesse seriam pesquisadas. É importante que os dados obtidos nesta fase sejam explicitados com algum grau de detalhe não apenas para que se possa apresentar o trajeto percorrido no interior da instituição, mas também para que mais adiante se possa identificar o quanto as diferenças 
na estrutura e organização institucionais interferem no seu modo de atuação. Assim, para proceder a tal explicitação, passa-se a expor resumidamente os princípios e textos legais a partir dos quais se organizaram o Ministério Público Federal e o Estadual, tomando-se emprestadas lições de doutrinadores já consagrados:

"Dois princípios básicos informam, tradicionalmente, a instituição do Ministério Público: a) o da unidade; b) o da independência funcional. Ser una e indivisível a instituição significa que todos os eus membros fazem parte de uma só corporação e podem ser indiferentemente substituídos um por outro em suas funções, sem que com isso haja alguma alteração subjetiva nos processos em que oficiam (quem está na relação processual é o Ministério Público, não a pessoa física do promotor ou curador). Ser independente significa que cada um de seus membros age segundo sua própria consciência jurídica, com submissão exclusivamente ao direito, sem ingerência do Poder Executivo, nem dos juízes, e nem mesmo dos órgãos superiores do próprio Ministério Público." 1

\section{Princípios da unidade e indivisibilidade}

"Devemos entender restritivamente os princípios da unidade e indivisibilidade em face das peculiaridades do Ministério Público brasileiro. Tomado em sentido abstrato, o ofício do Ministério Público pode ser considerado uno; contudo, isso não impede que haja vários Ministérios Públicos (Constituição da República, art.128). Assim, é possível admitir a unidade abstrata do ofício: quando a lei diz que o Ministério Público exercerá a ação penal pública, refere-se tanto ao federal como o dos Estados, tanto ao de um Estado como ao de outro. Contudo, tendo em vista nosso regime federativo, unidade de órgãos não existe (temos vários Ministérios Públicos). Por outro lado, a indivisibilidade também é mitigada: respeitada a discriminação legal de atribuições, as designações e substituições não são arbitrárias nem aleatórias e só podem ocorrer na forma da lei.

Entre nós, os princípios da unidade e da indivisibilidade têm de ser aferidos em cada Ministério Público (unidade sob o aspecto abstrato, de unidade do ofício; indivisibilidade como a possibilidade de substituição na forma da lei, preservado o princípio do promotor natural)." ${ }^{2}$

\section{Princípio do promotor natural}

"Além de ter a Constituição Federal de 1988 consagrado aos membros do Ministério

CINTRA, A.C.A. et al., 1983, p.177.

2 MAZZILLI, Hugo Nigro. "Independência do Ministério Público". In: FERRAZ, A.A.M.C., 1997, p.109. Grifos no original. 
Publico, pela primeira vez, idêntica garantia de inamovibilidade que têm os magistrados, ainda, a nosso ver, contemplou noutro dispositivo um princípio que tem íntima relação com este. Dentre as garantias fundamentais do indivíduo, assenta-se o princípio de que 'ninguém será processado nem sentenciado senão pela autoridade competente' (art. $5^{\circ}$, LIII).

(....) É o mesmo princípio do juiz natural, mas agora sob uma ótica diversa. Realmente, este é o primeiro direito do acusado: não só o de ser julgado por um órgão independente do Estado, mas, até mesmo antes disso, o de ser acusado por um órgão estatal dotado de igual independência, escolhido previamente segundo critérios e atribuições legais. (....) A inamovibilidade, como todos os demais predicamentos da instituição, destina-se antes a proteger a função do que, em si mesmo e pessoalmente, o ocupante do cargo. (....) Certo é que hão de harmonizar-se os interesses da coletividade tanto de não ser afastado indevida ou discricionariamente um promotor com atribuições legais para oficiar no feito, para atendimento de eventuais interesses menores dos detentores do poder, como o de poder ser afastado motivada e vinculadamente o promotor motivada e vinculadamente o promotor natural, desde que isso seja necessário para evitar que um órgão da instituição, por exemplo, comprometa o interesse público." ${ }^{3}$

\section{Princípio da independência funcional}

"O princípio da independência funcional opõe-se precisamente ao princípio da hierarquia, típico do Ministério Público francês, onde o Ministério Público é uno, indivisível e hierarquizado. Entre nós, é mais acertado dizer que unidade é o conceito de que o Ministério Público é um só órgão, com uma só chefia e uma só função. Por sua vez, indivisibilidade é o conceito de que, porque é o Ministério Público uno, torna-se possível a substituição de seus agentes. Contudo, em vez de hierarquia, no Ministério Público brasileiro temos independência funcional." ${ }^{4}$

"São condições para a independência do Ministério Público: (a) as garantias à instituição (nas suas atividades-meio); (b) as garantias a seu ofício (nas suas atividades-fim); (c) as garantias a seus órgãos e agentes (no exercício de suas atribuições funcionais)." 5

A instituição portanto exerce sua independência mediante a garantia de sua autonomia administrativa e financeira (atividades-meio); sua autonomia funcional (atividade-fim) e mediante a garantia de independência funcional dos seus órgãos e agentes.

MAZZILLI, H.N., 1993, pp.116-117. Grifos no original.

4 MAZZILLI, Hugo Nigro. "Independência do Ministério Público". In: FERRAZ, A.A.M.C., 1997, p.109. Grifos no original.

Idem, p.105. 
"Embora as leis do Ministério Público várias vezes tenham usado um conceito pelo outro, na verdade autonomia distingue-se de independência: enquanto independência é conceito absoluto, autonomia é conceito relativo (a autonomia deve ser considerada em relação a outros órgãos ou poderes).

(....) Além da autonomia funcional, ou seja, a liberdade de exercer o ofício em face de outros órgãos e instituições do Estado, a lei ambém assegura aos agentes do Ministério Público a independência funcional, que é a liberdade com que estes exercem seu ofício agora em face de outros órgãos da própria instituição do Ministério Público. (....) Excetuados os casos expressamente previstos na lei, em sua atividade-fim os membros e órgãos do Ministério Público não podem receber ordens como proponha a ação, ou deixe de propor, ou recorra, ou não recorra, ou sustente esta tese e não aquela." 6

A despeito de tais princípios norteadores da organização do MP já estarem concebidos e expressamente declarados em $1988\left(\mathrm{CF}\right.$, art.127, $\left.\S 1^{\circ}\right)$, foi apenas em 1993 que as leis orgânicas fixaram normas específicas, organogramas, atribuições e estatutos tanto para o nível federal como para o Estado:

\begin{tabular}{c|c|c|c}
\multicolumn{1}{c|}{$\mathbf{1 9 9 3}$} & 12 de fevereiro & 20 de maio & 27 de novembro \\
\hline Alcance Nacional & $\begin{array}{c}\text { LOMP } \\
\text { Lei Federal 8.625 }\end{array}$ & & \\
\hline Alcance Federal & & Lei Complementar 75 & \\
\hline Alcance Estadual & & & $\begin{array}{c}\text { LOMPMP/SP } \\
\text { Lei Complementar 734 }\end{array}$
\end{tabular}

6 Idem, pp.105-108. 


\section{Ministério Público Federal}

Na estrutura federal, o MP da União compreende os Ministérios Públicos Federal, do Trabalho, Militar e o MP do Distrito Federal e Territórios, todos sob a chefia do Procurador-Geral da República. ${ }^{7}$ Para este estudo interessa apenas um dos ramos do MPU, o MPF, vez que a ele cabe exercer a defesa dos direitos constitucionais do cidadão, sempre que se cuidar de garantir-lhes o respeito pelos Poderes Públicos Federais, pelos órgãos da administração pública federal direta ou indireta, pelos concessionários e permissionários de serviço público federal ou por entidades que exerçam outra função delegada da União. ${ }^{8}$

"São órgãos do Ministério Público Federal:

I - o Procurador-Geral da República;

II - o Colégio de Procuradores da República;

III - o Conselho Superior do Ministério Público Federal;

IV - as Câmaras de Coordenação e Revisão do Ministério Público Federal;

V - a Corregedoria do Ministério Público Federal;

VI - os Subprocuradores-Gerais da República;

VII - os Procuradores Regionais da República;

VIII - os Procuradores da República." 9

O Procurador-Geral da República, chefe do MPF, preside o Colégio de Procuradores e o Conselho Superior. Ao Colégio compete elaborar listas sêxtuplas para composição dos tribunais federais, ${ }^{10}$ eleger membros do Conselho e opinar sobre assuntos gerais de interesse da instituição. Ao Conselho compete exercer o poder normativo no âmbito do MPF, especialmente para elaborar e aprovar regimentos internos, normas para concurso de ingresso na carreira, designações para os diferentes ofícios, critérios para distribuição de inquéritos, procedimentos administrativos e outros feitos, critérios de promoção por merecimento, entre outros. $^{11}$

As Câmaras de Coordenação e Revisão (CCRs) são organizadas por função ou por matéria, competindo-lhes: promover a integração e a coordenação dos órgãos institucionais que atuem em ofícios ligados ao setor de sua competência, observado o princípio da

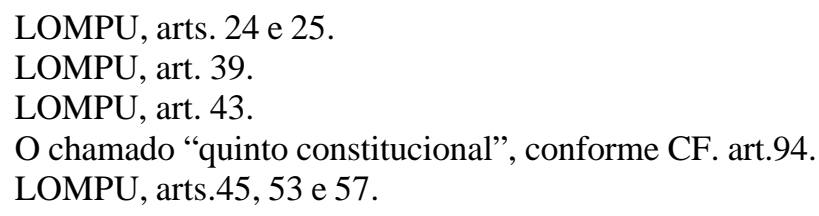


independência funcional; manter intercâmbio com órgãos ou entidades que atuem em áreas afins; encaminhar informações técnico-jurídicas aos órgãos institucionais que atuem em seu setor; manifestar-se sobre o arquivamento de inquérito policial, inquérito parlamentar ou peças de informação; resolver sobre a distribuição especial de feitos que, por sua contínua reiteração, devam receber tratamento uniforme; resolver sobre a distribuição especial de inquéritos, feitos e procedimentos quando a matéria, por sua natureza ou relevância, assim o exigir e decidir os conflitos de atribuições entre os órgãos do MPF. ${ }^{12}$

A Corregedoria é o órgão fiscalizador das atividades funcionais e da conduta dos membros do MPF, dirigida pelo Corregedor-Geral, a quem compete realizar correições e sindicâncias, instaurar inquérito contra integrante da carreira, acompanhar o estágio probatório e propor ao Conselho exoneração de membros que não cumpram as condições do estágio. ${ }^{13}$

Os Subprocuradores-Gerais são designados para oficiar junto ao Supremo Tribunal Federal, ao Superior Tribunal de Justiça, ao Tribunal Superior Eleitoral e nas Câmaras de Coordenação e Revisão; os Procuradores Regionais, para oficiar junto aos Tribunais Regionais Federais, e os Procuradores, junto aos Juízes Federais e junto aos Tribunais Regionais Eleitorais, onde não tiver sede a Procuradoria Regional. ${ }^{14}$ Paralelamente a estas funções, criou-se a figura da Procuradoria dos Direitos do Cidadão, ofício para o qual é designado um Procurador Federal para exercer a função pelo prazo de dois anos, sempre que possível sem acumulação com outras. Em cada Estado também será designado um Procurador Regional dos Direitos do Cidadão. ${ }^{15}$

\section{Ministério Público Estadual}

Já na esfera estadual, cabe ao MPE a chamada competência residual para a garantia dos direitos constitucionais do cidadão, excluída apenas a atribuição ratione personae reservada ao MPF quando a União Federal tiver interesse no feito, conforme visto acima.

De acordo com a Lei Orgânica Estadual do Ministério Público de São Paulo (LOEMP/SP), estabelecida segundo a Lei Orgânica Nacional do MP (LOMP), que dispõe

\footnotetext{
LOMPU, art.62.

LOMPU, arts.63 e 65.

LOMPU, arts.66, 68 e 70.

LOMPU, arts. 40 e 41.
} 
sobre normas gerais para a organização do MP dos Estados, a estrutura do MPE compreende órgãos de: ${ }^{16}$

\begin{tabular}{c|l}
$\begin{array}{c}\text { Administração } \\
\text { Superior }\end{array}$ & $\begin{array}{l}\text { 1. Procuradoria-Geral de Justiça } \\
\text { 2. Colégio de Procuradores de Justiça } \\
\text { 3. Conselho Superior do Ministério Público } \\
\text { 4. Corregedoria-Geral do Ministério Público }\end{array}$ \\
\hline \multirow{2}{*}{ Administração } & $\begin{array}{l}\text { 5. Procuradorias de Justiça } \\
\text { 6. Promotorias de Justiça }\end{array}$ \\
\hline \multirow{2}{*}{ Execução } & $\begin{array}{l}\text { 7. Procurador-Geral de Justiça } \\
\text { 8. Colégio de Procuradores de Justiça }\end{array}$ \\
$\begin{array}{l}\text { 9. Conselho Superior do Ministério Público } \\
\text { 11. Procuradores de Justiça }\end{array}$ \\
\hline $\begin{array}{l}\text { 12. Centros de Apoio Operacional } \\
\text { 13. Comissão de Concurso } \\
\text { 14. Centro de Estudos e Aperfeiçoamento Funcional } \\
\text { 15. Órgãos de apoio técnico e administrativo } \\
\text { 16. Estagiários }\end{array}$
\end{tabular}

A chefia do MPE incumbe ao Procurador-Geral de Justiça, a quem compete praticar todos os atos próprios de gestão, editando os atos decorrentes da autonomia funcional, administrativa e financeira da instituição, e presidir a Procuradoria-Geral de Justiça, o Colégio de Procuradores e o Conselho Superior do MPE.

O Colégio de Procuradores, órgão de administração superior e de execução, é integrado por todos os Procuradores de Justiça em exercício, competindo-lhe, entre outros, opinar sobre matéria relativa à autonomia do MPE, propor a criação de cargos e serviços auxiliares, modificações na Lei Orgânica e providências relativas ao desempenho das funções institucionais, ao aperfeiçoamento e aos interesses da instituição, assim como medidas para promover, com maior eficácia, a defesa de interesses sociais e individuais indisponíveis.

O Conselho Superior, também órgão de administração superior e de execução, é integrado pelo Procurador-Geral de Justiça, seu Presidente, pelo Corregedor-Geral do MPE, ambos membros natos, e por mais 9 (nove) Procuradores de Justiça, tendo por atribuições, dentre outras, baixar normas regulamentadoras do processo eleitoral para a formação da lista tríplice para escolha do Procurador-Geral de Justiça, elaborar as listas sêxtuplas para composição do quinto constitucional, aprovar o quadro geral de antigüidade, assim como

16 LOMP, art. $2^{\circ}$ e LOEMP/SP, arts. $4^{\mathrm{o}}$ a $8^{\mathrm{o}}$. 
sugerir a edição de recomendações, sem caráter vinculativo, aos órgãos do MPE para o desempenho de suas funções e adoção de medidas convenientes ao aprimoramento dos serviços e deliberar sobre a participação de membros do MPE em organismos estatais de defesa do meio ambiente, neste compreendido o do trabalho, do consumidor, de política penal e penitenciária e outros afetos à sua área de atuação. ${ }^{17}$

A Corregedoria-Geral é o órgão de administração superior encarregado da orientação e fiscalização das atividades funcionais e da conduta dos membros do MPE, devendo também avaliar o resultado das atividades das Promotorias de Justiça e, quando autorizada nos termos da LOEMP/SP, das Procuradorias de Justiça. São atribuições do Corregedor-Geral, entre outras, realizar correições e visitas de inspeção nas Promotorias de Justiça, acompanhar o cumprimento das metas por elas estabelecidas em seus Programas de Atuação, instaurar processos administrativos, aplicar sanções, remeter ao Conselho Superior relatório circunstanciado sobre a atuação pessoal e funcional dos Promotores em estágio probatório, propondo, se for o caso, o não vitaliciamento, fazer recomendações, sem caráter vinculativo, a órgão de execução, organizar o serviço de estatística das atividades do MPE. ${ }^{18}$

As Procuradorias de Justiça são órgãos de administração do MPE, com cargos de Procurador de Justiça e serviços auxiliares, instituídas por ato do Colégio de Procuradores de Justiça, em que são definidas a denominação das Procuradorias, de acordo com a área de atuação de cada uma, o número de cargos de Procurador de Justiça que as integram e as normas de organização interna e de funcionamento. Reúnem-se mensalmente para fixar teses jurídicas, sem caráter vinculativo, para encaminhar sugestões para elaboração do Plano Geral de Atuação do MPE, dentre outras atividades. ${ }^{19}$

As Promotorias de Justiça são órgãos de administração do MPE, com cargos de Promotor de Justiça e serviços auxiliares, integradas por Promotores encarregados de exercer as funções institucionais e tomar as medidas judiciais e extrajudiciais necessárias à consecução dos objetivos e diretrizes definidos nos Planos Gerais de Atuação e nos respectivos Programas de Atuação. ${ }^{20}$

As Promotorias são organizadas por ato do Procurador-Geral de Justiça, podendo ser Especializadas, Criminais, Cíveis, Cumulativas ou Gerais. Consideram-se Promotorias Especializadas aquelas cujos cargos que as integram têm suas funções definidas pela espécie

17 LOEMP/SP, art. $1^{\circ}, \S 3^{\circ}$, e arts. $9^{\circ}, 19,21,22,26$ e 36.

8 LOEMP/SP, arts. 37 e 42.

9 LOEMP/SP, arts. 43 e 44.

20 LOEMP/SP, art.46. 
de infração penal, pela natureza da relação jurídica de direito civil ou pela competência de determinado órgão jurisdicional, fixada exclusivamente em razão da matéria; Promotorias Criminais, com funções definidas para a esfera penal, exclusivamente; Promotorias Cíveis, com funções definidas para a esfera civil; Promotorias Cumulativas ou Gerais, aquelas cujos cargos que as integram têm, simultaneamente, as funções daqueles que compõem as Promotorias Criminais e Cíveis. Paralelamente podem ser constituídos Grupos de Atuação Especial, de caráter transitório, para consecução dos objetivos e diretrizes definidos nos Planos Gerais de Atuação e nos respectivos Programas de Atuação. ${ }^{21}$

Na sequiência de órgãos voltados à administração, dispõe a Lei Orgânica sobre os órgãos auxiliares, dispondo sobre os órgãos de execução mais adiante, em título dedicado às atribuições do MPE.

Os Centros de Apoio Operacional (CAOs) são órgãos auxiliares da atividade funcional do MPE, integrando o Gabinete do Procurador-Geral de Justiça, competindo-lhes estimular a integração e o intercâmbio entre órgãos de execução que atuem na mesma área de atividade e que tenham atribuições comuns, remeter informações técnico-jurídicas, sem caráter vinculativo, aos órgãos ligados à sua atividade, e estabelecer intercâmbio permanente com entidades ou órgãos públicos ou privados que atuem em áreas afins, para obtenção de elementos técnicos especializados necessários ao desempenho de suas funções. ${ }^{22}$

A Comissão de Concurso é órgão auxiliar de natureza transitória, incumbido de realizar a seleção de candidatos ao ingresso na carreira do MPE. ${ }^{23}$

O Centro de Estudos e Aperfeiçoamento Funcional visa ao aprimoramento profissional e cultural dos membros da instituição, de seus auxiliares e funcionários, bem como a melhor execução de seus serviços e racionalização de seus recursos materiais, podendo realizar ou patrocinar cursos, seminários, congressos, simpósios, pesquisas, atividades, estudos e publicações, bem como relacionar-se, celebrar convênios e colaborar, pelos meios adequados, com outros órgãos do MPE, com a Fundação Escola Paulista do MPE, com a Associação Paulista do MPE, com os demais Ministérios Públicos e Associações de Ministérios Públicos, com os institutos educacionais, universidades, ou outras instituições e entidades públicas ou privadas nacionais ou estrangeiras. ${ }^{24}$

LOEMP/SP, art.47, "caput" e $\$ 3^{\circ}$.

LOEMP/SP, art.51.

LOEMP/SP, art.52.

LOEMP/SP, arts.53 a 55. 
Os órgãos e serviços auxiliares de apoio técnico e administrativo do MPE são organizados e instituídos por ato do Procurador-Geral de Justiça e contam com quadro próprio de cargos de carreira que atendam suas peculiaridades, as necessidades da administração e as atividades funcionais. ${ }^{25}$

O estágio compreende o exercício transitório de funções auxiliares do MPE, por período não superior a três anos, incumbindo aos estagiários levantar dados de conteúdo doutrinário ou jurisprudencial, acompanhar diligências de investigação de que forem incumbidos (exceto as de polícia judiciária e para apuração de infrações penais), estudar as matérias que lhes forem confiadas, propondo adoção dos procedimentos conseqüentes, atender ao público (nos limites da orientação prévia), controlar a movimentação dos autos de processos administrativos ou judiciais, dentre outras atividades. ${ }^{26}$

As atribuições do MPE são exercidas pelos Procuradores e Promotores de Justiça, os primeiros junto aos tribunais, os segundos junto aos órgãos jurisdicionais de primeira instância. $^{27}$

Aos cargos de Promotor de Justiça é atribuída a função de atendimento ao público, na respectiva área de atuação, tomando as providências cabíveis. Aos cargos especializados são atribuídas as funções judiciais e extrajudiciais, nas seguintes áreas de atuação: Falências, Acidentes do Trabalho, Família, Infância e Juventude, Registros Públicos, Meio Ambiente, Consumidor, Mandados de Segurança, Cidadania, Habitação e Urbanismo, Execuções Criminais, Tribunais do Júri, Militares. ${ }^{28}$

Também ao Procurador-Geral de Justiça cabem atribuições processuais, como por exemplo impetrar mandados de injunção quando a inexistência de norma regulamentadora estadual ou municipal, de qualquer dos Poderes, inclusive da Administração indireta, torne inviável o exercício de direitos assegurados em normas constitucionais e infraconstitucionais ou exercer as atribuições do artigo 129, incisos II e III, da Constituição Federal, quando a autoridade reclamada for o Governador do Estado, o Presidente da Assembléia Legislativa ou os Presidentes dos Tribunais. ${ }^{29}$

Ainda com funções de execução figuram: o Conselho Superior, ao qual compete rever o arquivamento de inquérito civil ou de peças de informação; o Colégio de Procuradores, ao qual compete rever, mediante requerimento de legítimo interessado, decisão de arquivamento

\footnotetext{
LOEMP/SP, art.59.

LOEMP/SP, arts.76, 77 e 86.

LOEMP/SP, arts. 119 e 121

LOEMP/SP, arts. 294, § $6^{\circ}$, e 295.

LOEMP/SP, art. 116.
} 
de inquérito policial ou peças de informação determinada pelo Procurador-Geral de Justiça nos casos de sua atribuição originária. ${ }^{30}$

\section{Demandas}

O limite temporal proposto compreende o período 1988-1996. É preciso ressalvar que: o primeiro registro de demanda em matéria de saúde no MPF, em que os dados se encontram centralizados, data de 1989; com relação ao MPE, a atuação em saúde era dispersa em todos os órgãos, sem verticalização das demandas em função da matéria, até 1993, ocasião em que se consolidou a Promotoria de Justiça dos Direitos Constitucionais do Cidadão na Capital (PJC-CAP).

Até a criação da PJC-CAP a atuação era atomizada, o que por si só constitui dado para o período. Como já foi explicitado, um dos instrumentos para atingir o objetivo primário da pesquisa é conhecer as macro-estratégias da instituição, o que não necessariamente coincide com a somatória das atuações isoladas de seus membros. Busca-se mapear tendências institucionais a partir de um recorte suficientemente largo no tempo, e para isso o período desde a criação da PJC-CAP mostrou-se adequado para a análise.

Em vista da escassez de demandas imediatamente após a vigência da Constituição, e considerando que nosso objetivo almeja compreender a postura da instituição perante sua nova atribuição, e não descrever como a maioria ou a minoria de seus membros atua (embora esse levantamento seja um dos instrumentos para indicar a presença ou ausência de macroestratégias para o desempenho da função institucional), julgamos que o levantamento das demandas do MPE durante o período 1988-1993 não acrescentaria qualquer informação além daquela que a própria iniciativa de centralizar as demandas em matéria de saúde na PJC-CAP já indicava: a necessidade institucional de operacionalizar a matéria de forma sistemática. Este dado por si só revela que a instituição já demonstrava então que carecia de medidas globais para dar conta de interesses de trato coletivo, a exemplo da saúde. Essa necessidade vai se tornando evidente e corroborada ao longo do levantamento e das entrevistas, período em que se criaram inclusive grupos especiais de trabalho em torno de temas específicos, como no caso do PAS.

Ressalte-se também que a denominação pura e simples que a instituição atribuiu às divisões em seus organogramas não foi tomada como parâmetro para incluí-las ou excluí-las do campo de estudo. O parâmetro decisivo foi a localização das matérias que o estudo

30 LOEMP/SP, arts.117 e 118. 
contempla, tomando por base apenas a delimitação material explicitada na introdução. Um exemplo disto é a exclusão, no âmbito estadual, das Promotorias do Consumidor, enquanto no âmbito da Procuradoria da República, o assim chamado Ofício da Tutela Coletiva designado para a temática do Consumidor e Ordem Econômica foi incluído, uma vez que o órgão incumbido dessa temática trata também do aspecto qualidade do serviço público, a partir da consideração legal da adequada e eficaz prestação dos serviços públicos em geral como direito básico do consumidor. ${ }^{31}$

O fundamento para não coletar demandas encaminhadas à Promotoria de Justiça do Consumidor no Ministério Público Estadual não foi nossa postura quanto a estarem ou não os serviços públicos de saúde incluídos no direito consumerista, e sim a divisão estabelecida pela própria instituição: as Promotorias do Consumidor tratam das questões oriundas de contratos a título oneroso com empresas privadas prestadoras de serviços, estando a matéria relativa aos serviços públicos (e especificamente aos serviços públicos de saúde) concentrados na Promotoria de Justiça de Defesa dos Direitos Constitucionais do Cidadão.

Note-se portanto que a pesquisa neste momento evita qualquer inferência conceitual, buscando apenas e tão-somente revelar as diferentes visões e formas de operacionalização e divisão de trabalho adotadas pela instituição. Seria possível discutir, por exemplo, partindo de um conceito estrito de cidadania ao qual subjaz a noção de Estado, se é adequado atribuir o tratamento de serviços públicos de saúde às Promotorias de Justiça da Defesa da Cidadania, uma vez que a universalidade prevalece como um dos princípios do direito à saúde em nosso ordenamento, estendendo-o como direito de qualquer pessoa humana, nacional, estrangeira ou apátrida, independentemente do que se possa conceber por cidadania. No entanto, esta seria uma discussão que de pouco ou nada nos serviria, se o que buscamos é a concepção de direito à saúde que emerge da prática institucional, e não dos termos utilizados para designar atribuições, até porque alguns conceitos ainda carecem de construção teórica suficiente para que se firme algum consenso a seu respeito.

O tratamento das demandas consistiu de três fases:

1. Busca junto aos registros disponíveis na instituição;

2. Classificação e seleção do universo de demandas a ser estudado;

3. Acompanhamento da destinação dada às demandas.

Cabe notar que no MPF o acesso foi direto, ou seja, os livros de registro foram compulsados pessoalmente, destacando-se as demandas em matéria de saúde das demais;

$31 \mathrm{CDC}, \operatorname{art}^{\circ}, \mathrm{X}$, e art.22. 
já no MPE, este acesso direto foi possível apenas no Centro de Apoio Operacional das Promotorias

de Justiça da Cidadania (CAO-PJC). Como no âmbito da própria Promotoria (PJC-CAP) não foi possível obter autorização para acessar diretamente os controles cartoriais, o levantamento foi realizado de forma indireta, isto é, os registros foram listados por servidor administrativo designado para tal tarefa, instruído no sentido de adotar por critério a inclusão na pesquisa de toda e qualquer demanda alusiva ao tema saúde, considerado em sua maior amplitude possível.

Esta ressalva traz duas implicações: emprimeiro lugar, não se pode garantir que na PJC-CAP não haja mais registros afetos à área da saúde definidos por termos correlatos (radiação, e.g.); em segundo lugar, alguns poucos registros referidos em outros documentos escaparam à listagem, como se constatou mais tarde, já durante o acompanhamento, última fase de tratamento das demandas. De qualquer modo, como tais ocorrências não são numericamente representativas, esta circunstância não chega a comprometer quantitativamente o universo estudado, já que, repita-se mais uma vez, o que se pretende neste estudo é mapear a tendência e não exaurir as manifestações caso a caso.

Inicialmente, foram encontrados 234 registros no MPF e 140 no MPE. Desse total, isolaram-se aqueles registros que descreviam especificamente ações ou serviços de saúde objeto do estudo, de acordo com os critérios abaixo explicitados:

- Critério territorial: exclusão das demandas relativas a outras comarcas, no caso do MPF, por extrapolarem o recorte dado pelo limite espacial da pesquisa (Município de São Paulo), embora indiquem amplitude da atuação da Procuradoria da República, que atua em todo o Estado. Os casos que não indicam o município ou dão margem a dúvida quanto à denominação se referir a logradouro da capital ou município foram mantidos na primeira triagem, devido a dois critérios: (a) possibilidade de surtir efeitos na Capital e (b) possibilidade de revelar assunto de interesse especialmente relevante para o estudo. *

- Critério em razão da pessoa: manutenção de todas as reclamações, denúncias, representações ou qualquer outra denominação que se aplique a demandas não geradas de ofício, ainda que apontem para interesse meramente individual e não coletivo, para possibilitar o acompanhamento do retorno dado aos interessados. Ainda que a atribuição funcional do MP diga respeito à tutela coletiva, a razão para manter os procedimentos gerados por interesses aparentemente individuais no universo a ser classificado está em 
investigar até que ponto o MP verifica se tais matérias contêm indícios de aspectos que potencialmente afetariam interesses coletivos, antes de se desincumbirem delas.

- Critério em razão da matéria: agrupamento em categorias fundamentadas na Constituição. As categorias foram construídas a partir de expressões-chave que descreviam os registros das demandas levantadas, formando núcleos temáticos.** Buscou-se agrupar os núcleos temáticos segundo fundamentos constitucionais, e relacioná-los aos artigos que refletem tais fundamentos:

\begin{tabular}{l|l} 
Fundamento & \multicolumn{1}{c}{ Categoria } \\
\hline Art. 37 & Improbidade administrativa \\
\hline Arts.194 e 195 & Seguridade social \\
\hline Art. 196 & Princípios do direito à saúde: universalidade, igualdade, integralidade \\
\hline Art. 197 & Regulamentação, fiscalização e controle \\
\hline Art. 198 & Organização do SUS \\
\hline Art. 199 & Assistência privada \\
\hline Art. 200 & Vigilância em saúde
\end{tabular}

Depois dessa categorização, foram descartados do estudo, ainda em razão da matéria, os procedimentos cujos núcleos temáticos tratavam de questões não relacionadas ao direito à saúde sob a ótica de direito fundamental da pessoa humana, ou que simplesmente diziam respeito a aspectos gerais que se relacionavam à saúde por mero acaso, como poderiam se relacionar a educação, transporte, ou qualquer outro assunto. É o caso das demandas categorizadas como:

1. Improbidade administrativa, que em sua maior parte dizem respeito a irregularidades em licitações, sem guardar relação específica com o direito à saúde;

2. Seguridade social, cujo núcleo se refere exclusivamente a questões relacionadas à seguridade outras que não a saúde, como por exemplo as áreas da previdência ou da assistência sociais;

3. Assistência Privada, cujo núcleo se refere exclusivamente a questões alheias ao fundamento do direito humano à saúde, como por exemplo a fixação de mensalidades de planos privados, as cláusulas contratuais relativas a carências etc. Estes são assuntos que podem ser tratados pelo órgão do MP designado para abusos contratuais em qualquer matéria, não especialmente saúde. (Os procedimentos que faziam referência a entidades de assistência privada participantes do SUS de forma

Representadas no Anexo 1 por grifos em negrito e itálico, como nesta nota. 
complementar, sujeitas às diretrizes deste, foram incluídos na categoria Organização do SUS).

É preciso frisar que o fato de uma entidade envolvida em demanda ser estatal ou privada por si só não a inclui ou exclui do universo estudado: apenas são excluídas aquelas demandas cujo núcleo temático não se relaciona com as normas de Organização do SUS, nem com o poder de polícia exercido pelo Estado por meio de Vigilância em Saúde.

Em anexo encontram-se relacionados os atos registrados pela instituição, mantida fidelidade quanto à terminologia constante dos registros. Essa exposição exaustiva dos dados coletados em sua totalidade, e não apenas daqueles selecionados, tem pelo menos dois propósitos: o primeiro é simplesmente ilustrar a quantidade das demandas de saúde com que a instituição se defronta. O segundo propósito, de caráter qualitativo, é justificar a não pouco provável margem de erro que o primeiro momento de classificação acarretou, justamente porque se dispunha apenas da terminologia utilizada na recepção e registro das demandas por servidores administrativos não necessariamente afetos ao uso estrito de termos jurídicos. Apenas como exemplo, um determinado procedimento cujo núcleo temático fosse descrito pelas expressões irregularidades e unidades de saúde privadas poderia estar classificado em quatro categorias diferentes:

1. em Assistência Privada, se se considerar que as referidas unidades de saúde privadas não participam complementarmente do SUS;

2. em Organização do SUS, se forem conveniadas ou contratadas;

3. em Vigilância em Saúde, se as irregularidades dependerem de conhecimentos técnico-sanitários para serem apuradas, não se tratando de irregularidades perante a organização do sistema;

4. ou em Improbidade Administrativa, se as irregularidades não guardarem qualquer relação específica com a área da saúde.

Esta é uma observação que se faz necessária apenas e tão-somente nessa primeira classificação, antes de encerrado o acesso ao conteúdo das demandas, ocasião em que ajustes e remanejamentos foram feitos conforme sua maior ou menor aproximação com uma outra categoria.

Encerrada a fase de classificação e seleção conforme o escopo da pesquisa, as demandas foram reduzidas a 178 no MPF e 87 no MPE, definindo assim o universo a ser estudado. Constatou-se mais tarde que grande parte desse universo era constituído do que se apelidou procedimentos-satélite, i.e., desdobramentos de um procedimento central, que a ele se 
agregam por referência cruzada, e cujo andamento segue a estratégia definida globalmente.

Passou-se então à fase principal do tratamento dos dados, atingindo assim o primeiro objetivo instrumental do trabalho: acompanhar a destinação das demandas incluídas no universo a ser estudado, em busca dos argumentos utilizados para instruir os procedimentos, as promoções de arquivamento e respectivas homologações.

A partir deste ponto foram retomadas as principais questões a serem analisadas na pesquisa, sempre com vista às perspectivas descritiva, crítica e analítica, norteadoras da coleta do material objeto de discussão.

Quando as demandas redundavam em ações, foram consultadas também as razões e contra-razões levadas a juízo, pois --- ainda que o desempenho do MP junto ao Poder Judiciário não seja tema deste trabalho, por motivos já explicitados na delimitação do objeto --- a argumentação construída pelos membros do MP em peças processuais representou material de imensa utilidade, visto que freqüentemente era possível extrair dos textos concepções e convicções de interesse para o estudo.

\section{Entrevistas}

Os dados obtidos por meio documental foram em seguida verificados e/ou complementados junto a informantes-chave, por meio de entrevistas, distribuídas no tempo conforme os procedimentos indicavam a necessidade da complementação dos dados, sendo que a primeira data de 1996 e a última de 1998.

Foram realizadas ao todo 19 entrevistas: no MPE, 7 na base, 6 na cúpula, no total de 13; no MPF, 3 na base e 3 na cúpula, no total de 6. Esse número resultou da adoção de dois critérios gerados por necessidades distintas, uma formal, outra material.

Como primeiro critério, a preocupação em garantir amostra numericamente significativa dos membros do MP expostos às questões de fundo envolvidas na pesquisa. Este foi o critério para definir, no MPE, quantas entrevistas deveriam ser realizadas da $1^{\mathrm{a}}$ à $7^{\mathrm{a}}$ Promotoria de Justiça de Defesa dos Direitos Constitucionais do Cidadão: uma vez que para cada Promotoria haviam sido designados um Promotor titular e um Promotor auxiliar, num total de 14, optou-se por entrevistar o número correspondente ao número de Promotorias, realizando assim 7 entrevistas nesse universo.

Como segundo critério, visando garantir que o conteúdo dos dados pudesse de fato ser verificado e/ou complementado com as impressões subjetivas dos próprios membros do MP, a escolha dos entrevistados se pautou não apenas pelo cargo ocupado à época da entrevista, 
mas também e principalmente por experiências relevantes à pesquisa, adquiridas em qualquer momento de sua ocupação atual ou pregressa dentro da instituição.

Todas as entrevistas foram realizadas com base em roteiro aberto construído a partir das questões norteadoras do trabalho e do exame das demandas. Foram portanto incluídas perguntas correspondentes à perspectiva descritiva da estrutura e funcionamento do MP, das macro-estratégias institucionais e do encaminhamento das demandas; à perspectiva crítica sobre dificuldades conceituais e/ou operacionais e sobre atuação interinstitucional; e à perspectiva analítica das tendências da instituição. Para evitar indução de respostas, buscou-se concentrar a maior parte das perguntas em descrições, (perguntas $n^{\circ} 1,3,4,5,6,7$, 10, 11 e 12), intercaladas com perguntas de cunho crítico ( $n^{\circ} 2,8$ e 9), finalizando com uma única pergunta analítica que permitisse ao entrevistado apresentar sugestões amplas, discorrendo livremente sobre suas percepções $\left(n^{\circ} 13\right)$. Realizou-se pré-teste em que o relato descritivo embutia críticas/análises, dispensando a seqüência linear do roteiro, permitindo considerar as perguntas adequadas em sua disposição e conteúdo. ${ }^{32}$

${ }^{32}$ Anexo 2 - Roteiro de entrevista. 


\section{ANÁLISE}

A interpretação dos dados se pautou pelas perspectivas apontadas na Introdução (descritiva, crítica e analítica) e seus respectivos instrumentos. Neste capítulo busca-se reunir integralmente os resultados relativos à estrutura e o funcionamento institucionais, de modo a concluir quanto a seus efeitos sobre a eficácia da norma expressa no art.129, II, da Constituição. Inicialmente, serão apresentados comentários sobre o conteúdo da documentação levantada, assim como uma avaliação quantitativa e qualitativa das demandas, para que se possa em seguida discorrer sobre as dificuldades manifestadas pelos entrevistados. É importante ressaltar que os dados aqui reproduzidos textualmente tiveram mantidos os termos e expressões utilizados nas fontes, sem alterações, mesmo nos casos em que eventualmente pudesse haver imprecisões de qualquer natureza. ${ }^{1}$

\subsection{Estrutura}

Da mera leitura da documentação é possível extrair algumas observações. A começar pelas próprias leis orgânicas do MP, surgidas quando já se contava com a experiência acumulada durante cinco anos sob a nova Constituição. Além da repetição dos princípios constitucionais, já mencionada, a instituição busca reafirmar e até mesmo enfatizar algumas atribuições em sua lei própria, seja declarando-o expressamente no texto, seja organizando sua estrutura de modo a reservar recursos para dar conta de determinadas incumbências.

Assim, por exemplo, é possível encontrar na LOMPU o zelo pelos direitos constitucionais com tratamento de destaque em artigos ou mesmo em capítulos próprios: ${ }^{2}$

"Art.2 ${ }^{\circ}$. Incumbem ao Ministério Público as medidas necessárias para garantir o respeito dos Poderes Públicos e dos serviços de relevância pública aos direitos assegurados pela Constituição Federal."

Algumas pequenas alterações em textos basicamente idênticos ao constitucional também permitem supor a necessária fixação de alguns entendimentos, como é o caso do art. $5^{\circ}$, IV, da mesma LOMPU, que faz referência a serviços de relevância pública em comunicação social, avançando para além da saúde, única área até então declarada como tal, ou mesmo de redação mais precisa, como é o caso do art.11, que visa à garantia do efetivo

1 As citações não referenciadas em notas de rodapé correspondem a transcrições de trechos de entrevistas, identificadas por letras ao final de cada citação, correspondendo cada letra a um entrevistado.

2 LOMPU, Capítulo IV - Da defesa dos direitos constitucionais. 
respeito aos direitos constitucionais pelos Poderes Públicos e prestadores de serviços de relevância pública. ${ }^{3}$

As novas atribuições, antes de trazerem consigo a preocupação com o incremento no volume de demandas, foram recebidas pelos membros do MP como conquista de funções mais relevantes. O bom grado na assunção das novas tarefas é dado fornecido não apenas pelos documentos, mas confirmado diversas vezes durante as entrevistas:

"A função do art. 129, II, da CF, foi não só conferida ao Ministério Público pelo constituinte de 1988, como também foi buscada pelo próprio Ministério Público nacional. Assim, logo após a vigência da CF de 88, o Ministério Público de todo o país começou a especializar-se em matérias atinentes à defesa da cidadania, à defesa do patrimônio público, à investigação por meio de inquéritos civis em matérias atinentes aos serviços de relevância pública e aos direitos assegurados na Constituição. Houve até mesmo a criação de Promotorias novas, consolidando experiências informais anteriores, como as Promotorias de Justiça da Cidadania, de Habitação e Urbanismo, além das anteriores Promotorias de Justiça do Meio Ambiente e do Consumidor. E hoje já se estuda a criação novas Promotorias." (E)

"No MPF, a gente tinha uma característica muito própria, porque a gente fazia também a Advocacia da União até 1988. Então, é óbvio que a força de trabalho da Procuradoria da República estava voltada para a área tradicional do MP, que é a área penal, e a defesa da União. Com a Constituição, houve finalmente no âmbito do MPF uma divisão entre essa defesa da União e o papel do MP mesmo. Embora isso tenha sido previsto em 1988, só em 1993 é que de fato houve a separação, com a Lei Orgânica, em que há especificação das atribuições do MPF na defesa dos direitos constitucionais do cidadão e nos serviços de relevância pública. Foi um período longo entre 1988 e 1992, mas o que eu sei é que a Constituição foi fundamental para o MPF por causa desse rompimento. Com o fim da advocacia da União, a gente ficou mais liberado para a defesa do que a gente chama hoje de tutela coletiva." (C)

A organização interna em áreas de atuação teve diferentes evoluções no Ministério Público Estadual e no Federal. Enquanto no MPE a distribuição temática foi fixada desde a própria lei orgânica, atribuindo-se a área da saúde aos Promotores da Justiça da Cidadania e estabelecendo-se Promotorias e Centros de Apoio Operacional de acordo com critérios legais,

no MPF as áreas de atuação foram definidas e redefinidas por meio de atos administrativos,

3 Vide nota 2, na Introdução, sobre a redação constitucional do art.129, II. 
permitindo maior versatilidade na adaptação da estrutura à multiplicidade de combinações temáticas. No MPF, portanto, ainda que se tenha procedido a classificações de matérias que informassem o organograma, como é o caso das Câmaras de Coordenação e Revisão, foi possível manter mecanismos flexíveis que equilibrassem com decisões conjuntas a compartimentalização operacional em setores:

"Setor da Ordem Jurídica:

$1^{\text {a }}$ Câmara: matéria constitucional e infraconstitucional;

2 Câmara: matéria criminal e controle externo da atividade policial;

$3^{\text {a }}$ Câmara: matéria eleitoral;

Setor dos Bens:

$4^{\mathrm{a}}$ Câmara: meio ambiente e patrimônio cultural;

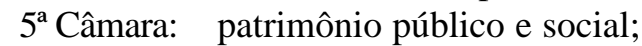

Setor das Pessoas:

$6^{\text {a }}$ Câmara: comunidades indígenas e minorias;

$7^{\text {a }}$ Câmara: família, criança, adolescente, idoso, deficiente, consumidor e outros interesses individuais indisponíveis, homogêneos, difusos e coletivos."

"As Câmaras integrantes de um mesmo Setor ou de Setores diversos podem reunir-se conjuntamente sempre que a matéria a ser submetida a deliberação implique providências a serem tomadas por órgãos institucionais que atuem em ofícios a elas vinculados."

"As Câmaras dos três setores podem reunir-se conjuntamente, integrando Conselho Institucional, para deliberar sobre matérias que demandem providências a serem tomadas por órgãos institucionais que atuem em ofícios vinculados a Câmaras de mais de um setor." 4

"Compete ao Conselho Institucional:

I - deliberar, mediante provocação dos interessados, sobre matérias que demandem providências a serem tomadas pelos órgãos institucionais que atuem em ofícios vinculados a Câmaras de mais de um setor, observado o princípio da independência funcional;

II - decidir, com recurso ao Procurador-Geral da República, o conflito de atribuições entre Câmaras e entre estas e órgãos institucionais que atuem em ofícios ligados aos setores de sua competência." 5

De fato, a não vinculação estanque a uma ou outra Câmara se fez perceber no levantamento de demandas cujas promoções de arquivamento haviam sido remetidas para revisão perante Câmaras diferentes, posto que não raro tratavam de matérias limítrofes que poderiam estar vinculadas a uma ou mais Câmaras. Além disso, quando se tratava de direito à saúde, as possibilidades de inserção se alargavam ainda mais, em função da Procuradoria dos Direitos do Cidadão, estrutura aparentemente paralela à das Câmaras:

Resolução no 6 , de 16 de dezembro de 1993 , do Conselho Superior do MPF, arts. $2^{\circ}, 6^{\circ}$ e $7^{\circ}$.

Resolução nº 20, de 06 de fevereiro de 1996, do Conselho Superior do MPF, art.11. 
"O que se queria na verdade com a LC 75/93, que foi uma lei muito esperada, porque nossa LOMPF era de 1951, já muito defasada, é que com a Procuradoria dos Direitos do Cidadão fosse garantido um espaço fixo para a tutela coletiva. A única diferença está na divisão de matérias. Numa Procuradoria pequena, quem faz a tutela coletiva é o Procurador Regional dos Direitos do Cidadão, o PRDC, que faz patrimônio, meio ambiente, índio, tudo. Isso porque o PRDC é quem cuida de cidadania. O que eu acho que é um pouco diferente é que o PRDC acompanha também as questões individuais administrativamente (que não vão redundar de maneira nenhuma em ação judicial, porque não tem legitimidade, encaminhando, quando é o caso, para a assistência judiciária, por exemplo). Isso porque a partir de casos individuais é possível identific ar questões coletivas. Em alguns casos, o PRDC acaba atuando como mediador, em algumas matérias cuja atribuição de execução não é do MPF, mas em que se pode contar com algumas entidades para monitoramento, como a Anistia Internacional, conselhos e outras organizações de direitos humanos, numa atuação institucional. Por exemplo, oPRDC recebe uma representação da Anistia Internacional que diz que determinado sindicalista foi assassinado em determinado lugar. O PRDC oficia então ao promotor, ao delegado, enfim, monitora o que está acontecendo. Mas em termos de execução, a atuação é igual à dos outros Procuradores." (C)

Esta maior ou menor margem de divisão de tarefas deixada pelas respectivas leis orgânicas aos membros do MP Estadual e do Federal por si só parece determinar diferentes graus de participação da base institucional em processos decisórios sobre a própria estrutura organizacional. A despeito da maior proximidade física entre cúpula e base no Estado, podese dizer que a interlocução é bem mais intensa entre os membros do MPF, o que pode ser atribuído ao fato de seu quadro de Procuradores ser bem menor que o de integrantes do MPE, mas também à abertura deixada pela lei para as várias possibilidades de integração conforme a experiência recomende.

Se há um fator marcante na estruturação dos serviços do MPF é a construção a partir da base institucional, em que se verifica um movimento sem dúvida ascendente na acomodação de critérios para distribuição temática, como se passa a relatar.

A organização da tutela coletiva até 1993 era encimada pela Secretaria das Coordenadorias dos Direitos e Interesses Difusos (SeCODID), havendo uma CODID em cada Estado.

"Essas estruturas passaram por vicissitudes, a CODID chegou a ser extinta aqui em S.Paulo, como se tivesse havido um contrafluxo, e depois voltou a ser implementada, 
agora sob o prisma da Secretaria dos Ofícios da Tutela Coletiva (SOTC), que na verdade mudou só de nome." (A)

No âmbito da Procuradoria da República em São Paulo, várias portarias tiveram por objeto a distribuição de matérias nos vários ofícios da tutela coletiva, que basicamente se dividiam em quatro grupos temáticos: o primeiro, abrangendo meio ambiente, patrimônio histórico e cultural, índios e minorias; o segundo, patrimônio público e social; o terceiro, consumidor e ordem econômica; e o quarto, família, criança, adolescente, idoso, portadores de deficiência e a matéria residual. Inicialmente, as portarias que regulavam essa distribuição chegavam a destacar saúde como um dos subgrupos do segundo ofício, relativo a patrimônio público e social. ${ }^{6}$ Logo em seguida, a subdivisão em grupos deixou de ser fixada por quem ocupava o cargo de Procurador-Chefe, passando a ser objeto de deliberação do conjunto de Procuradores em atuação na tutela coletiva, ${ }^{7}$ atribuindo-se aos membros que atuavam na área um poder de auto-organização cada vez mais amplo. Mais tarde, com base em deliberação conjunta, como faz constar em seu preâmbulo, outra portaria vem suprimir a subdivisão em grupos, permanecendo apenas, destacadamente, um único grupo especial, justamente o da saúde e educação, convertido posteriormente em quinto ofício da tutela coletiva. ${ }^{8}$

"Às vezes nós nos deparamos com a seguinte situação: vem uma notícia sobre prestação de serviço público do ponto de vista do consumidor, do usuário, ou do ponto de vista da utilização do erário público, ou uma questão meramente de funcionamento, negligência etc. Para melhor direcionar, buscamos detectar o ponto prevalente, predominante, o que salta primeiro aos olhos. Em função disso é que se dá a distribuição para um ofício ou outro, mas nada impede que a atuação seja conjunta entre quem é do patrimônio público, do consumidor ou da saúde, e toda essa montagem e distribuição é preponderantemente feita na base do consenso. Isso mudou muito, porque antes chegava uma representação que era jogada numa distribuição geral onde chega tudo, então ia no meio de processo, de tudo. Hoje, com essa especialização, com a criação de um setor específico para esse tipo de procedimento e essa organização em ofícios, é possível enquadrar de forma clara e nítida cada uma das representações, cada uma das demandas, mas tudo isso é feito em reuniões periódicas em que as matérias são discutidas com a participação de todos os colegas, sejam os que estão encarregados de determinado assunto ou mesmo os que não estão, mas têm familiaridade com o tema, ou porque já ocuparam a mesma posição ou porque desenvolveram a matéria por outras vias informais, buscando alcançar opiniões

\footnotetext{
Portaria $\mathrm{n}^{\mathrm{o}}$ 170/96, art. $1^{\circ}$.

Portaria $\mathrm{n}^{\circ} 171 / 96$, art. $1^{\circ}$, parágrafo primeiro.
} 
consensuais sobre a destinação a ser dada às demandas." (D)

Os efeitos dessa participação da base na organização estrutural até mesmo da cúpula são nitidamente visíveis quando se busca compreender, por exemplo, o critério diferenciador no encaminhamento de questões limítrofes que tanto poderiam se vincular à $5^{\mathrm{a}}$ como à $7^{\mathrm{a}}$ Câmara, ou ainda à Procuradoria dos Direitos do Cidadão:

"O PRDC aqui acumula permanentemente outras matérias. Trabalhando no ofício que trata de criança, adolescente, idoso, por exemplo, promove o arquivamento de seus procedimentos na $7^{\mathrm{a}} \mathrm{CCR}$. Enquanto $\mathrm{PRDC}$, não há sujeição. O que há é uma coordenação pelo Procurador Federal dos Direitos do Cidadão, o PFDC, para o tratamento das questões no país inteiro. Quando a gente arquiva procedimentos individuais, a gente tem arquivado junto ao PFDC. Isso tem sido debatido nos Encontros Nacionais de PRDCs, e saiu este ano a decisão de remeter de ofício para o PFDC, que homologa o arquivamento. Como a lei da ação civil pública prevê essa homologação de arquivamento dos procedimentos da tutela coletiva, no caso do MPF junto às CCRs, ficou solta aí a homologação dos procedimentos dos PRDC, porque são questões individuais. Então, tirou-se desse último Encontro é que agora vai haver a remessa de ofício. Até agora o que se fazia era remeter tudo para a $7^{\text {a }} \mathrm{CCR}$, fosse individual ou coletivo. Lá pelas tantas, a $7^{\mathrm{a}} \mathrm{CCR}$ deliberou só arquivar matéria coletiva, deixando para o PFDC o que fosse individual.

Todas essas questões vão tendo seus mecanismos criados a partir da prática dos Procuradores que estão na base, de baixo para cima, até que algumas condutas vão se tornando mais ou menos homogêneas. Isso tem funcionado assim, o que é bastante democrático. O que a instituição tem de orientação é criado pela base, não há orientação de cúpula, porque a nossa carreira tem uma diversidade muito grande. Você imagina que a realidade do Amapá não é a mesma daqui. Isso tudo é muito debatido, os Encontros servem bem para isso, porque é muito difícil a partir de Brasília ter uma visão da realidade. Por exemplo, agora houve uma tentativa de cima para baixo na regulamentação do inquérito civil, inspirada numa portaria do MP do Trabalho, que é outro ramo do MPF, e isso foi rejeitado totalmente pelos Procuradores da tutela coletiva aqui de S.Paulo e também no Encontro dos PRDCs, justamente porque essa regulamentação viria de cima para baixo. É preciso partir de cada experiência, de cada Procuradoria da República nos Estados, ou nos Municípios, onde há, e assim ir lapidando, lapidando, até que se chegue a um denominador comum para regulamentar. No $5^{\circ}$ Ofício, por exemplo, essa questão da saúde surgiu da necessidade: não há condições de se cuidar de todas as matérias, é preciso

$8 \quad$ Portaria $n^{\circ} 83 / 97$. 
dividi-las." (C)

Ao contrário do que se poderia imaginar, a declaração constitucional de relevância pública das ações e serviços de saúde não determinou de pronto a criação de divisões temáticas na estrutura do MP, nem no âmbito federal, nem no Estadual. É recorrente nos relatos dos Procuradores da República o fato de a complexidade do tema saúde ter sido 'descoberta' circunstancialmente, tendo se instalado com tamanha força e rapidez que se transformou em exemplo emblemático de especialização, tomado como referência no desenvolvimento de uma série de mudanças administrativas no interior do MPF, não apenas em S.Paulo, mas em todo o país:

"Não foi o fato de estar declarado na Constituição que provocou a iniciativa, foi o avanço natural a partir da própria magnitude do problema, que percebemos quando começamos a ter contato com o que isso representava em desvio de recursos, um serviço flagrantemente falido, a gente vê por aí o crescimento dos convênios médicos, e daí a opção: saúde é prioridade. No fim, essa prioridade foi admitida por todos os Estados e praticamente há quase dois anos, em todo encontro de Procuradores em Brasília, saúde tem sido um tema sempre insistentemente presente. Ou seja, não houve uma organização institucional automática para dar cumprimento à nova atribuição constitucional, toda a mudança que está surgindo partiu dos colegas que estão, digamos assim, no 'front', num movimento de baixo para cima, e assim como foi com a saúde, vai ser com tudo. Nunca houve um planejamento das atividades do MP em função das novas tarefas. É algo em que se insiste há algum tempo, mas não há, é a nossa prática do dia a dia que está impondo. Acúpula nunca viveu essa experiência, não sabe dessa necessidade." (D)

"Pelo processo histórico, primeiro, foram imaginadas forças-tarefas para tratar contingencialmente, temporariamente, de certos assuntos. A criação de um grupo destacado para cuidar das questões da saúde vinculadas ao patrimônio público se deveu àquela CPI do Congresso, que encaminhou a conclusão de seus trabalhos com a denúncia de algumas irregularidades específicas no Estado de SP. Então se resolveu criar uma força-tarefa para resolver esse problema da CPI, que era norteada pelo signo da temporariedade. Era como se se concentrassem esforços, mas por um espaço de tempo limitado. E porque vinculado às questões do patrimônio público? Porque dava a impressão de que a preocupação com a saúde era mais em função dos desvios de recurso, em função dos reflexos patrimoniais da má gestão dos recursos destinados à área da saúde, e não uma preocupação específica com o serviço público da saúde. Por exemplo, licitações fraudulentas para compra de medicamentos. Mas, afinal, no que essas licitações, essas irregularidades licitatórias, se distinguem de outras, em outras áreas? 
Ora, como as questões com saúde tomaram um vulto inimaginado em princípio, aquilo que era para ser o objeto exclusivo desse grupo específico acabou se tornando apenas um pontapé inicial. E pouco a pouco, esse espaço da Procuradoria da República foi tomado por questões novas que chegavam e que já não ficavam nada a dever àquela CPI. E ficaram se desvinculando cada vez mais das questões patrimoniais e sendo vinculadas efetivamente à prestação do serviço público de saúde, ou àmaneira como a saúde é vista pela população, porque também não interessa só o serviço público da saúde, mas a saúde enquanto um bem público mesmo, que eventualmente é prestado em nível particular. À medida que se tomou consciência dessa nova dimensão, a saúde primeiro perdeu o signo da transitoriedade, recebeu tônus de permanência, começou a aparecer na agenda, ganhar destaque nas agendas internas do MP em nível federal e em nível local. Já faz dois ou três anos que a saúde aparece como prioritária na agenda da PRDC e na agenda da SOTC de SP." (A)

"A proposta de S.Paulo já está sendo feita em outros Estados. No ano passado, quando houve o Encontro Nacional dos PRDC, os Procuradores destacados para o grupo saúde participaram e passaram para os outros Estados a idéia de destacar a matéria. Brasília também já tinha uma pessoa destacada. De um ano para cá, o RS também já designou um Procurador só para saúde, e o RJ também provavelmente vai ter um só para essa matéria. No ano passado, não tinha ficado claro que os Estados deveriam destacar Procuradores especificamente para isso. Este ano, no Encontro Nacional, uma das metas da agenda é justamente a criação do Ofício da Saúde nas outras Procuradorias, nos moldes de S.Paulo." (C)

"Havia o PRDC, que começou a trabalhar essa questão da saúde, porque havia um problema de fraudes, com uma vertente criminal muito grande, no sistema único de saúde, com relação às verbas, fraudadas por falsidade de AIHs, envolvendo também um aspecto de improbidade administrativa, aspectos de tutela coletiva, além de aspectos criminais. O que eu sei é que essa questão da saúde tomou essa dimensão, e foi quando se decidiu que devia haver Procuradores que só fizessem tutela coletiva. Quando se criou a SOTC, a saúde já era um assunto importante, mas estava dentro de patrimônio público e social. A saúde então era um grupo dentro do patrimônio. Aí é que se verificou que a saúde representava o que a gente chama de um ofício propriamente dito, quer dizer, envolvia política pública de saúde, o que era diferente, para além do aspecto patrimonial. Saúde, dentro do MPF, acabou sendo muito importante pelo controle das verbas do SUS, porque há uma parte de verbas federais muito grande. E isso é um problema básico, porque as pessoas morrem. Antes a gente atentava para as falsidades, adulterações relativas aos gastos, mas de repente começam a surgir problemas dos hemocentros, 
envolvendo a vigilância sanitária, ou seja, não há mais vínculo com a questão do repasse de verbas, mas com a política pública." (C)

"Aqui tivemos alguma dificuldade até de convencer os colegas de que a saúde era algo definitivo e importante a ponto de consolidar a área, porque se achava que a saúde não teria toda essa dimensão, que a matéria devia ser tratada sob o viés patrimonial, sob o viés do direito do cidadão, do consumidor, cada questão sendo tratada separadamente, sem que fosse necessária uma exclusividade, uma especialização, devendo a saúde permanecer como subgrupo do Patrimônio Público, que era mais o aspecto de patrimônio do SUS que interessava ao MPF. Esse trabalho de convencimento não foi fácil, mesmo junto aos colegas de S.Paulo, mas hoje o grupo está plenamente consolidado e o fato de haver órgãos destacados para essa função é padrão a ser seguido em outros Estados, é meta a ser atingida: todo Estado que tenha Procuradores em número suficiente para ter especialização, deve se especializar na área da saúde. Eu leio nisso um reconhecimento da importância da área." (B)

"Na evolução da estrutura da Procuradoria para absorver essa demanda de saúde pública, o estágio mais recente é a instalação de um núcleo na Procuradoria Regional, em que os Procuradores atuam em segundo grau, destinado à apreciação das questões de tutela coletiva. Isso foi um dos grandes momentos de discussão nessa avaliação da agenda de 1997, quando se traçou como diretriz a implementação de núcleos como esse que há hoje na Procuradoria em S.Paulo e em alguns outros Estados, prevendo um grupo de Procuradores destacados para fazer um acompanhamento de tutela coletiva em segundo grau. Antes todos faziam de tudo, agora esse grupo é específico para essas questões. É uma especialização que se firmou no primeiro grau e agora já contagiou o segundo grau. A intenção é que no futuro tenhamos nas cortes superiores também um grupo de Procuradores com essa especialização." (A)

Como se pode perceber, as discussões que se instalaram na base do MPF ultrapassaram as questões organizacionais, avançando no mérito de matérias reputadas mais relevantes, fixando entendimentos e gerando agendas de atuação. Destacam-se na área da saúde roteiros uniformizados de tratamento para problemas específicos, como: ${ }^{9}$

1. ausência de constituição e funcionamento dos Conselhos Municipais de Saúde

$\checkmark$ fiscalizar a composição dos conselhos

$\checkmark$ promover a participação da população nos conselhos

$\checkmark$ monitorar a implementação do processo de municipalização

2. ausência de capacitação dos integrantes dos Conselhos de Saúde

9 IV Encontro de Procuradores dos Direitos do Cidadão, 1996. 
$\checkmark$ empreender ações conjuntas com MPE visando conscientizar conselheiros de seu poder de fiscalização

$\checkmark$ buscar a participação das universidades visando capacitação

$\checkmark$ compilar textos informativos para distribuição aos conselhos

3. deficiência no gerenciamento financeiro por parte do Ministério da Saúde e dos gestores nos Estados

$\checkmark$ expedir requisições ao MS para que informe o caminho tomado pelos recursos internamente até seu recebimento pelo Estado ou Município, enumerando cada órgão, setor ou função que exerce no registro e controle de repasses

$\checkmark$ gestionar junto ao MS a formação de grupo de trabalho com participação do MPF, se for o caso, para racionalizar a forma de transferência, registro e controle das verbas da saúde para Estados e Municípios

4. ausência de controle, por parte dos gestores do SUS, da capacidade de internação e atendimento dos prestadores de serviço

$\checkmark$ recomendar aos gestores do SUS que realizem vistorias para recadastramento da capacidade de atendimento e internação dos prestadores de serviços; propor ação de produção antecipada de provas no caso de não o fazerem

$\checkmark$ verificar junto ao Tribunal de Contas da União auditoria recente nas gestões estaduais do SUS

$\checkmark$ recomendar prioridade na construção de hospitais públicos e a prestação pública do serviço de saúde

5. probabilidade de não aplicação da CPMF nos programas de saúde correspondentes ao exercício, sendo utilizadas para saldar débitos anteriores

$\checkmark$ acompanhar a votação da lei orçamentária através da assessoria parlamentar

$\checkmark$ encaminhar manifestação ao deputado relator e membros da comissão de orçamento

$\checkmark$ se necessário, verificar a viabilidade de representar ao Procurador-Geral da República para propositura da ação direta de inconstitucionalidade contra a lei orçamentária na parte que vier a destinar recursos da CPMF para outros fins que não a saúde no respectivo exercício

6. extinção do Fundo Nacional da Saúde

$\checkmark$ proceder ao aprofundamento jurídico dos efeitos da medida provisória que prorrogou o Fundo Nacional de Saúde limitando sua existência, em confronto com a Lei 8.080/90

7. existência de dupla cobrança por prestadores de serviços, que recebem via planos privados e via SUS pelo mesmo atendimento

$\checkmark$ recomendar ao MS que dê conhecimento ao Conselho Regional de Medicina respectivo, a fim de responsabilizar o diretor clínico da instituição

8. negativa de instituições filantrópicas em atender pacientes do SUS

$\checkmark$ recomendar ao MS que proceda a investigação a fim de aferir se está havendo recusa em atender pacientes do SUS

Ainda que se possa questionar o conteúdo das medidas propostas pelos Procuradores no que se refere a competências de outros órgãos, o exemplo acima demonstra a forte influência que a especialização na matéria ıpresentou na consolidação das práticas institucionais do Ministério Público Federal. 
O período que sucedeu as novas atribuições constitucionais levou também o Ministério Público Estadual a reconhecer a necessidade da especialização, com a diferença de mele a verticalização do organograma ser matéria de lei, o que acarreta reduzida mobilidade estrutural. Reflexo disto é a elaboração de um anteprojeto a ser apresentado à Assembléia Legislativa, prevendo a criação de cargos especificamente voltados à proteção do idoso, da pessoa portadora de deficiência, dos direitos humanos e da saúde pública, e prevendo também a possibilidade de transformar cargos nomenclaturados, durante sua vacância, em cargos inominados, estando as duas propostas assim justificadas, respectivamente:

"A evolução institucional fez ver a necessidade de se avançar na especialização das atribuições do Ministério Público, criando novas funções, redefinindo o exercício das tradicionais e principiando a agregar as criminais aos cargos especializados da Capital. A proposta, assim, racionaliza a atuação do Ministério Público e prioriza o atendimento a grandes demandas sociais, visando desencadear um trabalho mais eficaz em setores ainda não contemplados pela atual estrutura institucional." 10

"A inovação pretendida pelo artigo quer permitir ao Ministério Público adequar a estrutura de cargos da carreira às necessidades presentes e vindouras, de modo a possibilitar melhor distribuição de serviços entre os integrantes da instituição. Além disso, sinaliza à sociedade a preocupação dos Promotores e Procuradores de Justiça com a necessária reengenharia dos órgãos públicos, decorrente das novas concepções atribuídas às atividades do Estado contemporâneo. Autoriza o Ministério Público, enfim, a manejar o quadro de cargos sem necessidade de providências legislativas específicas, agilizando a atuação institucional em benefício das demandas mutantes da sociedade." 11

Em ao menos um ponto pode-se concluir pela coincidência dos rumos tomados pelo MPF e pelo MPE: ambas trajetórias corroboram a inegável interdependência de meios e fins, propondo-se ajustes administrativos à medida que as demandas expõem os profissionais a reflexões mais aprofundadas sobre cada matéria. O que varia nas duas estruturas é o espaço deixado para que esses ajustes se realizem com maior ou menor agilidade. A amplitude de um conceito tão indeterminado como o de 'serviços de relevância pública' serve muito bem para medir a mobilidade que tem o MP para determiná-lo conjunturalmente: enquanto para o MPF é possível criar administrativamente ofícios que lidem exclusivamente com um tema assim que este se destaque dos demais e "adquira relevância pública", o MPE se vê obrigado a encaixar as matérias que afloram e são reconhecidas como tal nos cargos previamente

10 Procuradoria Geral de Justiça. Esboço de Anteprojeto de Alteração da LOEMP, justificativa do art.55.

11 Idem, justificativa do art. 57. 
fixados. Evidentemente, as matérias contempladas com promotorias exclusivas, como é o caso do meio ambiente, acidentes do trabalho, consumidor, habitação e urbanismo, não se ressentem dessa indeterminação tanto quanto aquelas que acumulam as matérias residuais, como é o caso da cidadania.

"Como serviços de relevância pública que têm sido alvo de atuação, lembraria, entre outros, os serviços de amparo a idosos, inclusive em clínicas especializadas, públicas ou particulares; a fiscalização de locais onde se encontram menores (pelos Promotores da Infância e Juventude); os serviços de combate a desvios administrativos (pela Promotoria da Cidadania); a fiscalização da regularidade da prestação do ensino fundamental e das cobranças de mensalidades escolares (pela Promotoria do Consumidor); a fiscalização das finalidades sociais das fundações (pela Promotoria Cível); a fiscalização e o combate a acidentes do trabalho, não só em processos em andamento como em casos preventivos (pela Promotoria de Acidentes do Trabalho); a fiscalização da regularidade da implantação de loteamentos (pela Promotoria de Justiça de Habitação e Urbanismo); a fiscalização de empresas que violam o meio ambiente ou direitos do consumidor (pelas Promotorias de Justiça do Meio Ambiente e pelas do Consumidor); o combate à improbidade e ilegalidade administrativas (pela Promotoria de Justiça da Cidadania); a defesa do patrimônio público e social (idem)." (E)

"Vejo muitos outros serviços de relevância, aliás qualquer serviço público poderia ser objeto de exame pela ótica constitucional: transporte, segurança, incluída a questão penitenciária." (G)

Embora o anteprojeto de alteração da LOEMP contenha propostas que buscam ampliar esse espaço, está ainda longe de reverter a tendência dada na lei, tendo passado por duras críticas mesmo por órgãos da cúpula no que diz respeito à concentração de poderes na figura do Procurador-Geral de Justiça e nos órgãos superiores, tanto de administração como de execução.

Se, por um lado, o MPE se mostra sensível à necessidade de uma reformulação que permita o aproveitamento da experiência vivenciada na ponta da instituição, por outro lado percebe-se que o próprio anteprojeto reproduz características de um modelo institucional engessado. Assim como há orientações voltadas para a descentralização e para a absorção de dados externos, "obtidos no atendimento da população, nos processos, na imprensa, nos órgãos públicos e nas demais organizações da sociedade civil", "de acordo com as prioridades da comarca", objetivando-se "definir mecanismos que aproximem o Plano Geral de Atuação da realidade social, e que garantam nos Programas de Atuação a preponderância das necessidades locais sobre as metas genéricas estipuladas pela Administração Superior do 
Ministério Público", ${ }^{12}$ constam também do mesmo documento propostas no sentido de "aprimorar o sistema vigente na LOEMP, explicitando a atribuição exclusiva do Procurador-Geral de Justiça de propor ao Colégio de Procuradores de Justiça a constituição de Grupos de Atuação Especial", relegando às Promotorias de Justiça a mera possibilidade de sugerir a constituição de tais grupos. ${ }^{13}$

Essa procedimentalização excessiva das decisões organizacionais indica que no MPE ainda predomina uma certa tradição burocrática a desestimular justamente o debate interno que poderia rompê-la. Estes dois fatores - o formalismo e o desinteresse da base - como que se retro-alimentam num círculo vicioso que se evidencia nos desacreditados planos gerais de atuação, mecanismos pensados para superar os limites parciais das diversas matérias, e que supostamente estabelecem metas prioritárias globais a partir de propostas em cada área de atuação, mas que são freqüentemente criticados por se distanciarem da origem, perdendo especificidade em nome de uma generalidade que não traz resultados:

"Existem os planos gerais de atuação do Ministério Público, elaborados a cada ano; entretanto, os Promotores de Justiça, como agentes políticos, têm liberdade de atuação e decisão." (E)

"Na verdade, acho que o plano não deveria nem existir, porque não funciona e nem tem como funcionar. Ainda que tivesse, o modo como ele está sendo feito na prática não funciona, porque, por exemplo, se a gente tomar o plano atual, acidadania consta de quatro itens, que são uma parte pequena, e que sozinhos já ocupam um promotor o tempo todo. Outras áreas têm dez, vinte itens. Então, na medida em que toda a atuação do MP é declarada como sendo prioridade, não há prioridade nenhuma. Se fosse para existir um plano de atuação, seria para todos se reunirem e elegerem qual matéria seria a mais urgente." (F)

"Há uma grande crítica ao plano de atuação, do jeito que ele está formulado. Acho que ele tem que ser uma política institucional estabelecida de baixo para cima. Abre-se a oportunidade para as promotorias enviarem os seus programas, mas acho que não é isso que resolve. Os promotores de determinada área tem que fazer uma reunião, juntamente com o Centro de Apoio respectivo, o Conselho Superior, a Procuradoria, e aí sim traçar um plano temático, porque do jeito que está, não funciona. Antes eu até enviava sugestões, agora nem envio mais. O plano é muito genérico e não é vinculante, porque, dizem por aí, o promotor tem independência funcional. Ora, é preciso equilibrar a independência funcional com um plano vinculante, senão cada um vai continuar na sua

12 Idem, art.24. 
atuação individual. Acho que a lei deve ser mudada para mitigar esse conceito de independência funcional, que deve ser mantido, claro, até para evitar pressões, internas ou externas, mas não nos mesmos moldes da magistratura, porque o MP tem que ter uma linha de conduta, e essa linha tem que ser uniforme. Portanto, falta um caráter mais democrático no plano e algum nível de vinculação." (I)

"Os planos não funcionam muito, até porque esbarram no princípio do promotor natural e na independência funcional, e como cada um pensa de um jeito, é difícil padronizar. Além disso, não adianta ter um plano utópico, eleger que esse ano vamos cuidar da saúde pública, porque não há condição: o problema mais grave da PJC-CAP é o patrimônio público, que é assunto de representações do Tribunal de Contas, dos vereadores, dos deputados, e isso acaba sendo a prioridade." $(\mathrm{H})$

A constante referência ao princípio da independência funcional, seja para invocá-lo como valor absoluto, seja para relativizá-lo, traz à tona um aspecto central na compreensão do MP: a forte marca pessoal que os membros da instituição imprimem à sua atuação. Esta característica por si só não significa necessariamente desarticulação, mas a favorece na medida em que o trabalho conjunto somente existirá se esse for o desejo de quem o promove. Emoutras palavras, a independência funcional acaba servindo de fundamento para que a instituição deixe seus integrantes totalmente à vontade para se organizarem se assim o quiserem, ou não. As diferentes evoluções organizacionais no MPF e no MPE ilustradas acima demonstram com bastante nitidez o fato de que o MP assume a personalidade daqueles que o compõem, se articulando ou não conforme os ânimos determinem. Assim, a história se apresenta multifacetada em função de um mesmo aspecto, que é esse personalismo presente tanto no MPF --- em que a articulação se deu por iniciativa dos atores institucionais do momento, como poderia não ter se dado se fossem outros e não estes ---, como está presente também no MPE, em que, a despeito de exigências formais de se articularem planos, metas, diretrizes, estratégias, prioridades, o debate é fragmentado em grupos, acabando por esvaziar uma possível orientação institucional, que se é do interesse de alguns, ao menos não parecia ser o interesse predominante no período pesquisado.

"Há um desvirtuamento da idéia de independência funcional. Está faltando um pouquinho de auto-crítica interna, vamos encarar: nós temos muitas funções, mas não temos pernas para elas todas. Primeiro nós temos que vencer a resistência, estabelecer uma organização, como em qualquer empresa. Está faltando essa mentalidade um pouco empresarial, organizacional, na cabeça do membro do MP, que está muito acostumado a

13 Idem, art.25. 
trabalhar sozinho. Ele não pensa em conjunto: 'eu tenho autonomia, independência, então me fecho no meu gabinete e faço o que eu quiser'. Isso é muito arraigado, mas acho que isto já está sendo superado pela própria realidade, que impõe essa necessidade. Hoje o trabalho tem que ser em conjunto. Embora a gente tenha a SOTC dividida em ofícios, o tipo de intercomunicação que há é que sustenta essa organização. Praticamente, a experiência cotidiana de quem assumiu essas tarefas, como não havia outro referencial anterior, é que está impondo essa mudança. É a base que está impondo a identidade da instituição, a cúpula nunca pensou em se organizar em função dessas exigências." (D)

"Um problema estrutural importante a mencionar é a carreira, que está estruturada equivocadamente, porque gera uma dinâmica de acomodação perversa. Para ser sincero, dizer isto vai contra minha própria comodidade, mas acho que nossa carreira foi inspirada à imagem e semelhança do Judiciário, só que isso não faz o menor sentido, ainda mais hoje em dia, em que a iniciativa está dada para o MP, porque a magistratura fundamentalmente é inerte, até para a garantia da imparcialidade. Então, é razoável que o órgão judicante tenha garantias que conduzam à eqüidistância, sendo a inamovibilidade do cargo e a vitaliciedade as principais, o que para o MP não funciona, porque se o nosso horizonte não é a inércia, mas é a atividade, não podemos ter cargos inamovíveis, porque isso cria um efeito perverso. Essa garantia portanto teria que ser repensada de forma que aquele que se sentasse numa cadeira como promotor da cidadania fosse motivado a fazer mais pelo interesse público não a partir do seu próprio interesse de titular do cargo. Pessoalmente defendo que a grande solução fosse que todos os cargos do MP fossem por mandato certo. Findo o mandato, o promotor apresentaria para um órgão qualificado na própria instituição ou talvez até com possibilidade de ingerência de fora da instituição, devia ser até um órgão misto, para avaliar a atuação nesses dois ou três anos e o projeto para o futuro. Algumas áreas como a de consumidor, por exemplo, seguem uma determinada concepção, dentro de uma determinada linha, priorizando determinado tipo de ação, de atendimento ao consumidor, abrindo determinadas entradas na sua área, mas será que não vai chegar uma hora em que se exploram outros caminhos conforme o interesse público se altera? Claro que isso tudo é mediado pela linha do próprio promotor. Isso gera um mecanismo de motivação negativa, que leva o promotor, quando chega num cargo deste, chegar para não fazer, não chegar para fazer, porque ele está inamovível e pronto. Não que essas garantias tenham de ser quebradas, mas redirecionadas para uma dinâmica competitiva interna, voltada para o interesse público, para a sociedade, não para o próprio titular do cargo. Na magistratura é razoável que seja assim, porque o que se quer do juiz é a eqüidistância, a inércia, essas condições que são estritamente pessoais. No MP, o fator fundamental é o interesse público, então não faz sentido você ter esta 
estrutura de carreira que nós temos. Agora, mudar isso constitucionalmente, legalmente, é outro assunto. Veja que na PJC-CAP há 14 promotores, 7 titulares e 7 auxiliares, mas até no caso dos titulares, apenas dois estão em exercício, os outros todos estão afastados, convocados, o que seja. Dos outros cinco, apenas um chegou a trabalhar na PJC-CAP por um período de tempo razoável, os outros todos vieram só para ocupar o cargo, para ter o sentido patrimonial do cargo, para poder dizer que é promotor da cidadania. Vieram para cá por outros interesses, porque sabiam que ficariam deslocados em função de brigas políticas internas, o que não significa que teriam interesse em exercer o cargo, mas em estarem designados para ele, porque é um cargo importante, de destaque, e que interessa aos grupos políticos internos deter." (G)

Tais relatos mostram o quanto a condução dos desígnios institucionais está ao sabor de circunstâncias variáveis no tempo e no espaço, conforme os sujeitos que integram a carreira, indepedentemente do que disponha a lei. No limite, tamanha influência subjetiva pode se traduzir em uma tal atomização que o único fator a congregar todos os sujeitos acabe sendo o invocar o nome da instituição sempre que se trate de reconhecer sua autoridade.

Um aspecto digno de nota a corroborar esta impressão é que, invariavelmente, todos os entrevistados iniciaram suas respostas fazendo questão de alertar para o período em que haviam ingressado na carreira e justificando-se por fornecerem dados limitados à sua vivência individual. A evolução histórica da instituição parece ser sempre vista como tendência generalizada e destacada da história de cada cargo, como se estes não transmitissem aos novos ocupantes os efeitos das práticas anteriores. Ainda que se disponha de registros e procedimentos pendentes, a assunção de um cargo não pressupõe necessariamente o aproveitamento das experiências acumuladas pelos antecessores, no sentido de se criar uma memória institucional que sirva de referência para os sucessores.

"Supondo que eu fique aqui por dez anos, vai chegar uma hora que eu vou para outra área, e toda a minha experiência ficou perdida. Então, deveria haver uma preocupação de se institucionalizar essa experiência. Para isso, seria muito importante que houvesse debates em que se trocassem experiências. Isso não é socializado nem dentro da própria promotoria, o que acaba duplicando trabalho. No MPE existem várias instâncias de debate, escola, grupos de estudo, eventos, congressos, encontros, mas que são espaços extremamente contaminados por vieses políticos. Esses canais são muito viciados. Se você não é do grupo que está dominando, você não passa numa porta. Se havia antes uma afinidade e foi rompida, pode esquecer os canais institucionais. Não se pode dizer que haja uma avaliação séria de troca de experiências, até porque o brasileiro tem toda essa idéia de que seriedade é formalismo, então se vai haver uma reunião, compõe-se uma 
mesa com o excelentíssimo fulano e o meritíssimo ciclano e daí resulta muito palavrório inútil. Aqui na promotoria mal se consegue ter reuniões, porque, para ser bem sincero, um não suporta o outro, não dá para tematizar nada porque os egos se entrechocam, as opiniões de cada um têm de prevalecer e não acontece mais nada. Nas questões burocráticas ainda vai, mas de resto cada um trabalha por si ou, no limite, com quem tem um pouco mais de afinidade."(G)

A predileção por esta ou aquela matéria ou a especialização pessoal em determinada área são critérios levados em consideração apenas pelo próprio interessado em exercer determinado cargo, não havendo qualquer previsão na carreira que permita concluir que a instituição valorize a disposição ou conhecimento como diferenciais na sua atividade-fim. Embora a atuação em várias áreas seja tida como enriquecedora e mesmo recomendável no início da carreira, na opinião de vários entrevistados, parece não haver exceções à regra de que a simpatia especial pela matéria é determinante quando há possibilidade de escolha de cargo:

"Há um tempo atrás, quem entrava para o MP tinha uma expectativa profissional de atuação na área criminal. Isso era muito claro. Se fizessem testes vocacionais naquela época, iam perceber que o perfil dos integrantes era o perfil de quem atua nas lides criminais e também a estrutura da instituição era toda voltada para isso: as melhores cabeças, os melhores espaços, o melhor tempo, os integrantes do MP ocupavam espaço nas conferências de direito criminal. Isso mudou. Com a Constituição de 1988 e com o tempo que ela precisou para ser implementada, isso mudou radicalmente. Hoje é possível ingressar no MPF e passar toda a sua vida sem ter atuado na área criminal. Eu sou um desses casos. Eu não teria vindo para cá se não fosse a possibilidade de atuar numa área, digamos assim, cível, ou não penal pelo menos, e também não sobreviveria imaginando que um dia ou outro eu devesse passar por uma experiência criminal." (A)

"Para um certo tipo de conduta na instituição, é preciso ter algum tipo de informações ideológicas, isso é quase inevitável. Não se consegue ser engajado todo o tempo na defesa dos direitos humanos, se você não tiver um determinado perfil ideológico, um substrato coerente com sua atividade. Inevitavelmente, são pessoas com formação mais progressista, com muita influência de esquerda." (D)

Por carecer de mecanismos que incentivem a produção intelectual nas matérias pouco aprofundadas ou direcionem o foco sobre as áreas de atuação mais demandadas, a instituição mais uma vez relega a decisão sobre a forma e o conteúdo de suas funções ao voluntarismo, perdendo o controle justamente sobre o que dele se poderia extrair de mais precioso, que é o pendor natural de cada um para desempenhar uma tarefa e não outra. Semisso, a instituição 
acaba respondendo à demanda que vem ter às suas portas muito mais em função do que pode oferecer segundo o perfil de seus quadros do que propriamente em função do que a sociedade requer.

"O fato de a atuação estar nas mãos do promotor é uma característica do Ministério Público, que tem seu lado positivo, porque às vezes o colega vai investigar determinada matéria que para ele é um nicho interessante e para o outro, não. Tem também o lado negativo, que é a atuação ficar meio dispersiva." (H)

Até as investigações de cunho cível e penal sobre um mesmo caso são realizadas por órgãos diferentes, às vezes sem qualquer intercâmbio. As tentativas de reunir os trabalhos em torno de objetos de tutela parecem ser lentas justamente por força da resistência em atuar numa área que não seja de agrado pessoal.

"Nós pensamos em fazer isso na tutela coletiva, o que nós chamamos de ofício híbrido, reunindo as preocupações com os aspectos cíveis e penais de um problema, mas há uma certa resistência, porque se criou muito segmentada a instituição, então parece que são ramos que não se misturam. Mas esse tipo de coisa também tende a mudar na medida em que a gente permitir que quem está na área cível passe à criminal, quem está em 'custos legis' venha para a tutela coletiva e desta para a criminal e para 'custos legis', e que isso tudo seja aceito com uma certa normalidade. Se não houver preferência por nenhuma das áreas, se consegue, mas o que tem acontecido é que essa atividade tradicional de 'custos legis' em mandado de segurança, por causa desse perfil de agente que o MP preferentemente tem, não é mais vista com muito bons olhos, porque já não é nada atrativo nos lançarmos a imensos pareceres, quando podemos intervir de modo efetivo, ainda que na esfera administrativa para resolver o problema. Isso está mudando bastante, mas ainda falta um planejamento. Acho que de qualquer modo, estamos avançando. Por exemplo, organizamos o núcleo nos Estados para cuidar de tutela coletiva, chegamos ao ponto de especialização que S.Paulo tem. Em função das ações que não andavam em segundo grau, insistimos, insistimos e se formaram núcleos de acompanhamento de ACPs em segundo grau. Como hoje isso existe em SP, RS, Brasília também está se organizando, insistimos com o Procurador-Geral que criasse isso para o STJ, então hoje temos Subprocuradores Gerais da República que estão encarregados de acompanhar as ACPs, gostando ou não. A autonomia, a independência, ficou um pouco de lado porque o MP já se lançou nessa empreitada. São mudanças que estão ocorrendo. Mesmo a organização das Câmaras foi feita por reconhecimento a essa demanda, porque antes da Lei Complementar, nós tínhamos a Secretaria das CODIDs e se percebeu que as atividades dessa Secretaria apontavam para o filão mais interessante, que eram as ACPs, a mudança na prestação de serviços públicos, então foram criadas as diversas Câmaras, mas 
as pessoas que assumiram não tinham essa experiência da área. As mudanças foram provocadas." (D)

Embora se tenha notícia de grupos híbridos no MPE, criados bem depois do período estudado, para tratar conjugadamente de todos os aspectos envolvidos em matérias como direito do idoso e saúde pública, a nova tendência está longe de ser significativa, não apenas em termos de alocação de recursos como de atuação individualizada.

"O grupo de atuação especial tem uma função de estudar, propor soluções, diretrizes, e atuar em conjunto com o promotor natural, quando o promotor natural concorda. Eles podem ser órgãos de execução se o promotor natural concordar. Por exemplo, há um problema que o grupo do idoso descobriu em S.Bernardo, mas o promotor de S.Bernardo não quis atuar junto. Nesse caso, os integrantes do grupo do idoso não puderam atuar. Aí é preciso transformar aquilo num papel que vá chegar na mesa do promotor, que então vai ter que dar um destino porque não pode se negar. Portanto, é uma atuação muito prejudicada, na medida em que não se corresponde muitas vezes à urgência que o caso requer. Assim como o grupo de atuação do idoso foi formado numa promotoria criminal, um grupo de atuação especial da saúde pública poderia ser criado no âmbito das promotoria da cidadania, como o grupo do PAS, que foi um grupo informal, nem chegou a ser formalizado como de atuação especial. Agora, o grupo do idoso tem uma atuação muito mais localizada, a saúde pública é um assunto muito maior." (F)

\subsection{Funcionamento}

Estas considerações sobre a estrutura do MP, sua forma de organização e distribuição interna de competências, são extraídas a partir do ideário institucional explicitado em documentos e opiniões. Já a aferição do funcionamento, do conteúdo das funções desempenhadas, dependerá da análise sobre o conjunto de casos concretos a que está exposta a instituição na prática diária de seus profissionais. Passa-se assim às constatações que emergiram da captação e encaminhamento dessas demandas.

Uma primeira constatação decorre, sem dúvida, dos números. Considerando o total de registros encontrados no período, não se pode negar que a demanda tende a crescer a cada ano, apesar de lenta:

\begin{tabular}{c|c|c|c|c} 
& \multicolumn{2}{|c|}{ MPF } & \multicolumn{2}{c}{ MPE } \\
Ano & Representações & Ex-officio & Representações & Ex-officio \\
\hline 1989 & 1 & 2 & $\mathrm{x}$ & $\mathrm{x}$ \\
\hline 1990 & 2 & $\mathrm{x}$ & $\mathrm{x}$ & $\mathrm{x}$ \\
\hline 1991 & 4 & $\mathrm{x}$ & $\mathrm{x}$ & $\mathrm{x}$ \\
\hline 1992 & 3 & $\mathrm{x}$ & $\mathrm{x}$ & $\mathrm{x}$ \\
\hline
\end{tabular}




\begin{tabular}{c|c|c|c|c}
\hline 1993 & $\mathrm{x}$ & $\mathrm{x}$ & 3 & $\mathrm{x}$ \\
\hline 1994 & 10 & 1 & 13 & $\mathrm{x}$ \\
\hline 1995 & 42 & 28 & 20 & 2 \\
\hline 1996 & 73 & 11 & 37 & 11
\end{tabular}

O fato de o ano de 1995 ter apresentado um pico no número de procedimentos instaurados de ofício no MPF, chegando a representar $40 \%$ do total de demandas naquele ano, se deveu principalmente a uma auditoria sobre faturamento de AIHs realizada em diversos hospitais, desdobrada em mais de vinte procedimentos-satélite.

Do total de 234 demandas registradas no MPF, 18 foram excluídas do estudo em razão da matéria, conforme os critérios apresentados no segundo capítulo. Isto significa que cerca de 7\% das demandas registradas na Capital como matéria de direito à saúde tratavam predominantemente de outras matérias que com esta guardam apenas uma relação paralela, como sistema de seguridade social, cláusulas abusivas ou publicidade enganosa na assistência médica privada ou irregularidades em licitações. Já no MPE, a porcentagem de registros excluídos cresceu para 37\%: num total de 140 demandas tidas como de direito à saúde, 53 registros foram categorizados no art.37 da Constituição, referindo-se, portanto, a questões de improbidade administrativa. Ou seja, considerando apenas a área de saúde pública, as demandas de direito à saúde propriamente ditas têm no MPE uma chance 30\% maior do que no MPF de concorrerem com questões de improbidade administrativa relacionadas à saúde. Evidentemente, não estão contabilizados aqui os procedimentos de improbidade administrativa nas demais áreas, e com os quais a saúde também compete na mesa do Promotor da Cidadania.

Pode-se perceber desde logo que as demandas envolvendo saúde pública, conforme se originem no MPF ou no MPE, têm as definições de sua inserção temática bem diferenciadas. Conforme prevaleça um aspecto ou outro, poderão ser distribuídas na esfera federal para um Procurador que atue no ofício da saúde, ou do patrimônio público e social, ou do consumidor, ou ainda para o PRDC, enquanto na esfera estadual serão todas distribuídas para a PJC-CAP, com exceção apenas daquelas consideradas matéria de direito consumerista, caso em que são atraídas para a Promotoria do Consumidor.

A distribuição inicial, portanto, segue os critérios da organização em ofícios ou em promotorias, e dificilmente há redistribuição em função da matéria. Daí resulta que quanto mais especializada a divisão, menor o risco de uma matéria ceder espaço para outra com a qual o Procurador ou Promotor se sinta mais familiarizado. Neste aspecto é nítida a conexão que se estabelece entre a estrutura e o funcionamento do MP, pois na medida em que as 
matérias são separadas verifica-se como que uma indução institucional ao interesse pelo tema, em torno do qual se aglutinam as atuações.

"Há um efeito reflexo dessa especialização que a Capital gera, mas uma grande provocação são os próprios fatos que acontecem no Município, por exemplo uma Santa Casa que anuncia o fechamento, e a gente daqui fornece alguma orientação. Mas uma vez que o Procurador no Município tenha entrado nessa área da saúde, a volta é irreversível, porque aí ele experimentou e percebe. Euma vez que as pessoas conhecem mais um canal de atuação nessa área, há um efeito multiplicador, o Procurador vai sendo mais e mais requisitado, criando-se um fluxo de trabalho." (B)

"A educação já é um objeto que foi destacado da Promotoria da Cidadania para a da Infância e Juventude. É um exemplo típico de que a verticalização da matéria favorece a atuação. Nesse caso, a educação foi destacada da Cidadania, onde vinha se arrastando, sem ninguém conseguir fazer nada a respeito dela, e aí se instalou uma promotoria para tratar especificamente dos interesses difusos e coletivos da criança e do adolescente: em poucos meses, a repercussão do trabalho dessa promotoria foi excepcional, porque obviamente demandava tempo para que houvesse dedicação a essas questões, para ir atrás de procedimentos que em grande parte são formais, envolvendo o Tribunal de Contas e tudo o mais, enfim, o resultado foi muito claro e de repente surgiram várias outras questões, ligadas principalmente à educação." (G)

"Pelo que eu sei, a área do meio ambiente tem desenvolvido um trabalho assim, mais democrático. Os promotores se reúnem mensalmente, elegem um tema, estudam e preparam toda a investigação, a estratégia, e depois é que se ingressam com ações." (I)

De fato, esse efeito aglutinador a partir da especialização tem no MPE um exemplo fortíssimo na Promotoria do Meio Ambiente, que introduziu em sua rotina o Protocolado Geral, um novo instrumento gerado para dar conta das especificidades da matéria. O paralelo com a Promotoria do Meio Ambiente é de enorme serventia ao estudo, e será por isso mesmo referido mais de uma vez, porque, além de guardar relação especialmente estreita com a saúde pública, apresenta dificuldades comuns às matérias de tutela coletiva.

"Até cerca de três anos atrás, a Promotoria do Meio Ambiente atuava de acordo com os procedimentos comuns do Ministério Público, para recebimento, investigação e apuração de denúncias. Os problemas concretos eram resolvidos de forma pontual e isolada. Havia na Promotoria, por exemplo, denúncias de que quatro ou cinco empresas de mineração estavam operando de forma irregular, degradando o meio ambiente. Decidimos, então, fazer um levantamento de todas as mineradoras que funcionavam na Comarca de S.Paulo e verificar quais estavam em situação regular sob o ponto de vista ambiental. Com esse 
trabalho nós tivemos um panorama do problema da mineração no contexto ambiental na cidade de S.Paulo. Nós tínhamos também o mesmo problema com empresas de ônibus. A Promotoria tinha várias denúncias de empresas de ônibus que estavam emitindo fumaça preta acima dos limites e sentimos a necessidade de levantar o número de empresas de ônibus que circulam e investigar, de uma forma abrangente, a questão em termos de poluição atmosférica. Criamos, então, um procedimento que não vimos em nenhuma outra Promotoria e que batizamos de Protocolado Geral: é um procedimento investigatório a respeito de situações globais que nunca vimos na legislação do MP brasileiro ou americano. Ele funciona de forma simples: um dos colegas preside - por escolha interna - a pesquisa de um assunto (mineração, por exemplo) sob o ponto de vista geral. Os fatos concretos de interesse que são apurados, são distribuídos na Promotoria entre todos os colegas, que realizam um trabalho individual de investigação e até de responsabilização de cada uma das empresas poluentes. A intenção é a obtenção de um diagnóstico geral sobre os temas ambientais, que possibilite uma atuação singular mais eficiente por parte da Promotoria. (....) Na verdade, não havia uma compatibilidade entre a atuação individualizada (casos pontuais) e a ação global da Promotoria, que conseguimos conciliar com esse novo instrumento que se encontrou para sistematizar as informações gerais." 14

Considerado o entrecruzamento de objetos que se relacionam a saúde pública, urbanismo, meio ambiente, acidentes do trabalho, consumo de produtos e serviços, patrimônio público, para ficar com poucos exemplos, não é difícil imaginar que haja demandas afetas ao direito à saúde espalhadas nos diversos ofícios e promotorias, inclusive criminais. Um funcionamento integrado que permita trabalhar pontualmente um tema levando-se em conta os aspectos circunjacentes, reunindo as diversas atuações em torno de resultados mais amplos, superará ou não essa divisão estrutural em ofícios e promotorias, mais uma vez, se essa for a iniciativa pessoal de quem estiver atuando:

"O desmembramento é muito comum, porque os vários aspectos vão ganhando mais relevância. Quando o tema é híbrido, atraindo vários ofícios, o procedimento entra em pauta na nossa reunião quinzenal de todos os ofícios, que é avaliado em conjunto para então se definir qual o ofício mais afeto à matéria. Existem casos em que há cooperação de Procuradores em torno de um mesmo procedimento. Há que se considerar também um fenômeno bem interessante: quando você instaura de ofício algum problema, você se sente um pouco o pai daquela matéria, quer acompanhar o assunto, e não gostaria de ver o

14 Entrevista com Promotores do Meio Ambiente. Revista da Associação Paulista do Ministério Público, Ano I, n' 9, Agosto de 1997, pp.6-9. 
assunto com outro colega para quem talvez aquilo não seja prioritário. Então, sem nos furtarmos às regras da distribuição, a gente procura atender a mais esse critério, da 'paternidade' do feito, porque trabalhar em conjunto funciona muito melhor quando um se responsabiliza pelo procedimento e outro apenas agrega elementos. Essa é uma distribuição muito mais interna de trabalho, então há procedimentos comigo que envolvem assuntos nada relacionados à saúde, porque eu suscitei a questão, então acabo trabalhando em cooperação com o Procurador da área, porque já há um estudo do assunto, ou há uma proximidade com determinada matéria, enfim, para aproveitar o potencial que os colegas têm mesmo por fora de sua atribuição formal.

Um exemplo de problemas de saúde que tem ficado com a área de consumidor são os planos de saúde que não respeitam contratos. Se o problema envolver ao mesmo tempo um aspecto a ser acompanhado sob o enfoque contratual e outro sob o ponto de vista do atendimento da saúde, o provável é que ele seja desmembrado em duas medidas, mas se a opção for por uma medida só, o trabalho será conjunto. Não há um critério rígido. O que há são critérios democraticamente discutidos internamente para a divisão do trabalho. O mesmo acontece com os colegas da área criminal: nós temos o nosso procedimento, e eles, outro, mas há uma interação, uma colaboração, como tomar depoimentos juntos, emprestar provas, intercambiar subsídios, impressões quanto ao tema específico etc. Quando há demanda relativa a instituições, por exemplo, de saúde, com as quais estamos mais familiarizados, o colega criminal normalmente nos procura. Em geral, quando há reflexos no crime, a gente avança um pouco aqui para já passar o caso um pouco mais 'redondo para o colega da área criminal." (B)

Em que pesem tais iniciativas bem-sucedidas, é do desenho estrutural da instituição que depende a maior ou menor certeza de que um tema será abordado integralmente, pois quanto mais verticalizado estiver no organograma, menos estará sujeito a decisões quanto a atuar conjuntamente ou não.

Cabe aqui uma ressalva no que se refere à interferência de uma especialidade em outra: é preciso cuidar para que o fundamento usado na divisão organizacional que trate exclusivamente de determinada matéria não atinja as possibilidades de tutela por outras divisões. Exemplo disto pode ser encontrado em uma súmula de estudos do Centro de Apoio do Consumidor, firmando entendimento que nega a qualquer outro setor a possibilidade de invocar o Código do Consumidor na aplicação a serviços públicos de saúde: ${ }^{15}$

15 Ministério Público do Estado de São Paulo. Promotorias de Justiça do Consumidor: atuação prática, 1997, pp.67-8. Súmula de Estudos CENACON nº 6 - Junho/92, atualizada em maio/96. 
"São objeto de tutela pelo Código do Consumidor, e de atribuição das Promotorias de Justiça do Consumidor, os serviços públicos prestados uti singuli e mediante retribuição por tarifa ou preço público, quer pelo Poder Público diretamente, quer por empresas concessionárias ou permissionárias, sobretudo para os efeitos de seu art.22. Não o são, 
porém, os serviços públicos prestados uti universi como decorrência da atividade precípua do Poder Público e retribuído por taxa ou pela contribuição a título de tributos em geral. Nesse caso, tais serviços poderão ser objeto de inquérito civil e ação civil pública pelo Ministério Público, mas por intermédio do setor de defesa dos direitos do cidadão."

O fundamento para tal diferenciação encontra-se assim manifesto: "educação, saúde, etc., enquanto serviços públicos por excelência, eis que prestados pelo Poder Público por expressa disposição constitucional, são possíveis pela atividade tributária genérica do Estado, ou então pela cobrança de taxas; ao contrário, os serviços de transporte, água, energia elétrica, telefonia, gás etc., ainda que prestados diretamente pelo Poder Público, são individualizáveis e remunerados por 'tarifa', que é 'preço público' e não taxa. Com efeito, é extremamente complexo investigar-se a natureza do serviço público, por tentar surpreender, neste ou naquele caso, o traço de sua essencialidade. Com efeito, cotejados em seus aspectos multifários, os serviços de comunicação telefônica, de fornecimento de energia elétrica, água, coleta de esgoto ou de lixo domiciliar, todos passam por uma 'graduação de essencialidade' que se exacerba justamente quando estão em causa os serviços públicos difusos (uti universi), relativos à segurança, saúde e educação, e outros particularizados (uti singuli, como atrás elencados, exemplificativamente). Nesses casos de serviço público tarifado, o Poder Público é o fornecedor, pois o consumidor paga por aquilo que consome (tarifa), e que é fornecido pelo Estado. O preço do serviço só aparece com a utilização do seu serviço. Situação diversa ocorre com relação à saúde e educação, que são deveres do Estado, por expressa disposição constitucional. Esses serviços, porém, não são considerados como de relação de consumo, pois são possibilitados pelos pagamentos de tributos, os quais os contribuintes pagam por dever, e não porque utilizam os serviços. Não existe aqui relação de consumo, entrega de quantidade a ser paga e a utilização feita. A relação jurídica que então se apresenta é entre o contribuinte (aquele que é cadastrado ou lançado para pagar impostos, segundo De Plácido e Silva) e o Poder Público."

Essa interpretação, quando aplicada a serviços prestados pelo SUS, conduz a uma possibilidade que soa no mínimo intrigante: a de se eximirem estes serviços das obrigações exigidas pelo CDC, "sobretudo para os efeitos do seu art.22": adequação, eficiência, segurança e, sendo serviços essenciais, continuidade. A adoção generalizada desse entendimento levaria, em última análise, à desconsideração do CDC como instrumento de controle das ações e serviços públicos de saúde, respaldo legal de que poderiam se valer não 
apenas as Promotorias da Cidadania, mas todos os legitimados a exigirem judicialmente sua aplicação.

O fato de haver alguma discordância doutrinária não foi, ao menos neste caso, levado em consideração. Cite-se, apenas a título de exemplo:

"Qualquer serviço público - seja público stricto sensu ou de utilidade pública, seja uti universi ou uti singuli - deve ser prestado de forma adequada, eficiente e segura. (....) O Código não disse o que entendia por serviços essenciais. Essencialidade, pelo menos neste ponto, há que ser interpretada em seu sentido vulgar, significando todo serviço público indispensável à vida em comunidade, ou melhor, em uma sociedade de consumo. Incluem-se aí não só os serviços públicos stricto sensu (os de polícia, os de proteção da saúde), mas ainda os serviços de utilidade pública (os de transporte coletivo, os de energia elétrica, os de gás, os de telefone, os de correios). A lista não segue ad infinitum, devendo ser rigidamente jungida aos casos de efetiva imprescindibilidade. E este conceito, como tantos outros no direito do consumidor, é mutável, conforme evoluam as necessidades da sociedade de consumo." 16

"(....) se demonstrado que o serviço de saúde pública não foi prestado de forma adequada, eficiente, segura e contínua, por se tratar de serviço essencial, caberá ao consumidor o direito de acionar o Estado com base no art.22 do Código." 17

Ainda que a discussão do mérito não integre o escopo deste estudo, esta questão serve para salientar quão deletéria pode se tornar a fixação de um critério rígido na divisão estrutural: o fundamento utilizado meramente para fins operacionais, uma vez declarado como postura institucional, constituiria forte argumento da parte contrária caso algum Promotor da Cidadania se utilizasse de entendimentos diversos colhidos na doutrina para exigir a aplicação do CDC a serviços prestados pelo SUS. Embora esta questão específica não tenha sido levantada como dificuldade por nenhum dos entrevistados --- deixando pairar a dúvida sobre já ser tida como superada ou sobre não ser sequer cogitada ---, não é difícil perceber, numa situação como esta, como as próprias contradições internas podem fragilizar a atuação do MP como um todo.

É claro que a estrutura também depende do modo como será utilizada para que seus propósitos se verifiquem na prática, mas o fato é que a especialização faz com que se perceba

16 BENJAMIN, Antonio Hermen de Vasconcellos, "Comentários aos arts.12 a 27". In: OLIVEIRA, Juarez de (coord.). Comentários ao Código de Proteção do Consumidor. São Paulo: Saraiva, 1991.

17 CAZZANIGA, Gláucia Aparecida Ferraroli, "Responsabilidade dos órgãos públicos no Código de Defesa do Consumidor". In: Revista de Direito do Consumidor, n.11, 1994, pp.144-160. 
na abordagem integral de um tema uma necessidade, muito mais que uma opção na forma de trabalhar. Um Procurador da República designado para atuar em matéria de saúde poderá, por exemplo, dividir o trabalho daquelas demandas que envolvam verbas do SUS com seu colega designado para atuar em matéria de patrimônio público, dedicando-se cada um a atentar para um aspecto, alternativa de que já não dispõe o Promotor da PJC-CAP, que acumula as duas matérias. Embora se possa imaginar, neste exemplo, que os procedimentos no MPF tenderiam a se distanciar, enquanto no MPE a concentração de saúde e patrimônio público num único órgão geraria um procedimento mais abrangente, é preciso lembrar que tudo quanto possa se relacionar com direitos da cidadania estaria reclamando igual tratamento amplo por parte de uma mesma pessoa.

"Talvez o maior problema disso tudo é que uma Promotoria da Cidadania que se proponha a fazer um serviço de garantia dos direitos da cidadania deve ter iniciativa. Obviamente, quando você sobrecarrega essa Promotoria com um monte de coisas como patrimônio público que não são propriamente dessa área, que são casos extremamente trabalhosos com resultados difíceis de se obter, com um volume de documentação muito grande, que desviam a atenção e inibem a iniciativa do promotor, porque ele tem pilhas e pilhas de processos que mal cabem fisicamente na sala, é evidente que vai ter menos iniciativa." (G)

Já quando uma única matéria está sendo o foco central das atenções, o trabalho integrado com colegas de outras áreas deixa de ser considerado no plano da iniciativa pessoal e passa a se impor como necessidade inerente à própria especificidade do direito cuja tutela se deve promover. É o que exemplifica a Promotoria do Meio Ambiente:

"(....) Há uns dois ou três anos se estabeleceu uma divisão (de trabalho entre as Promotorias de meio ambiente e de loteamento clandestino), até porque nós estávamos atuando de forma dúplice. Quando o loteamento está em fase inicial de implantação e os riscos de danos ambientais são maiores, o caso é da Promotoria do Meio Ambiente. Mas se já existem moradias consolidadas, ele é da Promotoria de Urbanismo, que vai estudar o loteamento do ponto de vista da regularização, levando em conta também os aspectos ambientais ali envolvidos, da mesma forma como nós cuidamos dos aspectos do loteamento em si e do consumidor que adquiriu o lote e, se for possível, ajudamos na regularização do loteamento, ainda que em fase inicial de implantação. Já existe uma integração maior entre as Promotorias, mas o importante é termos critérios compatíveis de atuação.

Quanto às questões criminais, a Procuradoria-Geral precisa, com urgência, dar uma atenção especial para a questão e definir se vai destacar promotores criminais para tratar 
com prioridade esses casos ou se vai trazer para nós essa atribuição, com o aumento do número de promotores. (....) Poderia se destacar, por exemplo, em cada uma das Promotorias, um colega que preferencialmente cuidasse dos crimes ligados aos interesses difusos, não só ambientais, mas do consumidor, de loteamento clandestino, entre outros. (....) $\mathrm{Na}$ verdade, com certos ilícitos ambientais você tem uma situação muito específica. $\mathrm{Na}$ questão do desmatamento, por exemplo, não podemos pensar isoladamente porque existe um dano maior associado, resultante da somatória de todos os desmatamentos. Eles têm um impacto muito potencializado. Muitas vezes, para poder calcular uma estratégia de reparação ou de recomposição da área desmatada, você precisa calcular esse impacto geral. Então, só um órgão do MP que na verdade dispusesse dessa informação mais completa, conjunta, é que poderia estar estabelecendo essa estratégia. Há certas situações em que você não vai poder individualizar. Esse talvez fosse o argumento maior no sentido de agregar a atuação criminal às Promotorias Especializadas." ${ }^{18}$

Essa gradativa aproximação com matérias estranhas à formação jurídica aos poucos vai sensibilizando a ponta da instituição para a complexidade da tutela coletiva, a exigir uma atuação menos atomizada em procedimentos e mais direcionada por estratégias que superem os limites das Promotorias, mesmo que especializadas. Se antes o universo de demandas de relevância pública se constituía apenas e tão-somente daquelas que ingressavam por via de representações, já se nota ultimamente uma tendência a buscar instrumentos que permitam avaliar quão significativa é essa amostra com relação ao potencial de questões tidas como as mais relevantes no contexto social, o que certamente envolve um trabalho a nível institucional que procure conhecer a situação -- da saúde, por exemplo -- independentemente do que a sociedade lhe traga ou deixe de trazer.

As limitações da atuação isolada em casos que apontam para problemas mais amplos são evidenciadas em grande parte das demandas, por vezes sendo mesmo explicitadas como razões para promoção de arquivamento.

"Os fatos, em verdade, não guardam a dimensão que lhes foi dada na representação. Com isso, não se afasta a realidade da grave crise que assola a saúde pública, quer pela falta ou insuficiência de recursos materiais e humanos, quer pela escassez de recursos financeiros. Os discursos são inúmeros, os estudos incontáveis, diversas medidas administrativas são tentadas, planos de melhoria são, de forma continuada, sucessiva e por vezes, injustificada, reciclados ou substituídos, tudo em busca de soluções eficientes para o problema da saúde pública, que, entretanto, aponta para a indesejável, porém

18 Entrevista com Promotores do Meio Ambiente. Revista da Associação Paulista do Ministério Público, Ano 
notória, falência do setor de saúde. Não obstante o nefasto conteúdo desta desestimulante situação, o que se verifica in casu é a ausência de elementos concretos que possam, nos estreitos limites do que constituiu objeto de investigação, respaldar qualquer ação ministerial no âmbito de atuação desta Promotoria de Justiça da Cidadania." 19

"Em virtude da desestruturação que está havendo na saúde pública do Município, não se podem fazer julgamentos precipitados à procura de responsáveis pela situação, tendo em vista a precariedade do atendimento do SUS na Capital como um todo. Assim sendo, verifica-se que não existem outras providências a serem tomadas em relação aos fatos noticiados na representação inicial, sendo certo que a questão de maior abrangência, ou seja, a realização de medidas de medicina preventiva pela Municipalidade, nas mais diversas áreas, há de ser apurada separadamente." 20

A própria auditoria realizada no MPF que gerou dezenas de procedimentos-satélite, conforme já mencionado, pode ser interpretada como uma tentativa de abarcar toda a amplitude dos problemas apontados por casos repetitivos. No entanto, para que se tenha uma noção da absoluta insignificância de uma atuação individualizada no universo a ser auditado, basta dizer que a auditoria se propôs a periciar, com seis ou sete profissionais requisitados junto ao Ministério da Saúde, as 50 prestadoras de serviços com maior faturamento, de um total que ocupava 112 páginas apenas para ser listado.

"Os relatórios encaminhados dão notícia de que mensalmente o número de procedimentos realizados em algumas unidades ambulatoriais ultrapassa o montante de 200 mil. Verifica-se, pois, que é praticamente inviável realizar-se, de uma vez só, perícia capaz de determinar os reais montantes que, eventualmente, tenham sido indevidamente cobrados pelas 50 instituições. Nesse contexto, deverá ser realizada uma auditoria preliminar, com o objetivo específico de verificar, com base em critérios de amostragem, a confiabilidade do SIA/SUS no âmbito do Estado de S.Paulo. Determino que, numa primeira etapa, sejam auditadas apenas 3 instituições (uma pública, uma filantrópica e uma privada). Destaco ainda que mesmo as auditorias das três instituições selecionadas serão realizadas através de um critério de amostragem, com objetivo de tão-somente fornecer elementos sobre a confiabilidade dos controles utilizados e das cobranças efetuadas. A necessidade de extensão dos trabalhos será, por outro lado, posteriormente definida, a partir dos resultados preliminares que forem obtidos." 21

\footnotetext{
I, no 9, Agosto de 1997, pp.6-9.

19 PJC-CAP 135/96.

${ }^{20}$ PJC-CAP 273/95.

21 IC $32 / 95$.
} 
Mesmo a abrangência da perícia, cujo objetivo se restringia a concluir pela confiabilidade do sistema de controle, foi colocada à prova quando da solicitação de dados sobre uma das instituições, que pudessem instruir investigação do MPE sobre aquisição superfaturada de remédios e fraudes em subutilizações de leitos. A resposta esclarecia que ainda não havia sido concluída a perícia, e que esta, de qualquer modo, não tinha por objeto as instalações hospitalares, senão as ambulatoriais. Dois anos depois de iniciados os trabalhos, ficou decidido que os peritos seriam devolvidos ao Ministério da Saúde, "em face dos poucos resultados obtidos". Não é difícil imaginar que, ainda no caso de o procedimento redundar em conclusões mais consistentes, o controle do SIA/SUS não se esgotaria nisso, e sua continuidade certamente ofereceria obstáculos intransponíveis, a menos que se intentasse uma ação permanente com as instituições de controle interno do SUS, evitando duplicação de esforços desnecessários.

Medidas fundamentadas na "necessidade de conhecer melhor o sistema" foram também tomadas no MPE, por vezes de modo inusitado, como a experiência de um promotor que chegou a simular visita a um paciente para 'sentir a situação' do hospital, a ilustrar a premente necessidade da aproximação interinstitucional.

Passa-se a um exemplo concreto, extraído da práxis institucional, que chama a atenção pela crueza com que temas incomuns ao dia-a-dia do profissional do direito podem ser trivialmente tratados sem que este se aperceba da gravidade não circunscrita aos termos de uma representação. Trata-se de encaminhamento de informações à PJC-CAP, pela Procuradoria da República, após arquivamento de inquérito policial pela falta de provas e prescrição da pretensão punitiva, para que se apurassem as responsabilidades não criminais. Do inquérito, constavam testemunhas da existência de um 'freezer' nas dependências do Instituto Médico-Legal (IML) que, segundo a denúncia, servia para manter guardadas hipófises humanas retiradas de cadáveres submetidos a necrópsia. Segundo a denúncia, quando acumuladas em volume considerado suficiente, as glândulas eram vendidas a laboratórios estrangeiros para produção de hormônios de crescimento. Responde a PJC-CAP em sua promoção de arquivamento:

"O impacto da denúncia, tornada pública sob a forma de escândalo, fez por certo com que o indiciado e eventuais co-autores desmontassem 'o esquema' utilizado para a retirada, coleta e envio das glândulas de modo que não houvesse tempo suficiente para a coleta de vestígios materiais da ocorrência." 22

22 PJC-CAP 329/95. 
Ainda que se tentasse relativizar a importância do caso em si, sob o argumento de que os órgãos de controle devem priorizar seus escassos recursos na proteção de pessoas vivas, o exemplo serve perfeitamente para o que se quer demonstrar: o simples fato de um 'freezer' para essa finalidade estar permanentemente instalado no Instituto denota uma confiança absoluta na impunidade e na ausência de toda e qualquer fiscalização, seja no próprio IML, por parte do Centro de Vigilância do Estado, seja em portos, aeroportos e fronteiras, por parte do Ministério da Saúde.

"Uma promoção de arquivamento é uma peça jurídica, da qual não posso inferir que haja um problema maior. Pode ser que sim, mas de forma geral, não se pode extrair isto de uma peça que tem sua fundamentação jurídica sobre um determinado fato localizado. Quando se tem conhecimento de um problema que ocorre em vários pontos, é possível se preparar de forma jurídica, às vezes de forma técnica, para atuar de modo mais ágil. Isso já aconteceu em outras áreas, em saúde pública ainda não, mas nesses casos havia um problema que ocorria em mais de um local. Agora, não podemos ler uma peça jurídica e tirar a conclusão de que o fato pode estar ocorrendo em uma escala maior." (F)

Como este, vários casos poderiam ser citados para o mesmo efeito. Sem um fluxo de informações que lhe permita estar familiarizado com a dinâmica interna do SUS e identificar falhas sistêmicas com alguma facilidade, torna-se impossível ao MP desempenhar sua função de controle, garantindo que essa e outras práticas não se perpetuem.

Este ponto remete à atuação dos Centros de Apoio Operacional (CAOs), órgãos sem correspondente no MPF, aos quais a LOEMP atribuiu o papel, entre outros, de estabelecer intercâmbio permanente com entidades ou órgãos públicos ou privados que atuem nas áreas temáticas relacionadas à matéria designada a cada $\mathrm{CAO}$, para obtenção de elementos técnicos especializados necessários ao desempenho de suas funções. Para identificar seus interlocutores, os CAOs supostamente monitoram o volume das demandas, de modo a transformar esses dados em matéria-prima na solução não tópica de problemas crônicos.

"Há um convênio com a Secretaria da Saúde, que prevê colaboração na fiscalização de transplantes, incluindo a possibilidade de um promotor precisar de uma perícia, um médico que diga se determinado paciente poderia ou não ser transplantado, esse tipo de coisa. Se houver uma incompatibilidade sangüínea, por exemplo, é mais fácil, porque se trata de um conhecimento comum, mas como é que a gente vai saber os critérios de destinação de um órgão para um paciente e não para os outros quatro, se isso envolve conhecimento médico? Esse convênio visava estabelecer uma rotina de intercâmbio permanente de informações; na verdade, esse convênio até o momento não rendeu frutos, 
porque a questão do transplante, da fila única, ficou muito mais complicada do que devia, tanto por razões internas da Secretaria, como por razões externas, opções de prioridades etc. Mas o convênio visava isto, uma facilidade de comunicação e uma periodicidade, não que a gente fosse lá fiscalizar, ao contrário, eles nos enviariam mensalmente tudo que tivesse envolvido com isso, a ser avaliado nas Promotoria." (F)

O funcionamento dos CAOs é bem diferenciado conforme a época em que se criaram, uns mais novos que outros, e conforme, de novo, seu grau de especialização.

"Temos planos de implantar algo assim também, mas a súmula de estudos não é vinculante, uns podem entender de um modo, outros, não. Além disso, o funcionamento dos CAOs não é o mesmo: por exemplo, mês passado, o CAO da cidadania registrou 72 ações civis, enquanto a área de consumidor teve 9, apesar de haver igual número de promotores nos dois. A estrutura é a mesma, mas na cidadania a área de atuação é muito maior, o que proporcionalmente faz sua estrutura ser muito inferior. Até porque consumidor e meio ambiente existem desde 1985, e o CAO da cidadania é de 1992. Além de serem mais antigos, têm muito mais experiência, recursos doutrinários, e também uma área de abrangência muito menor, o que faz com que os assuntos de consumidor e meio ambiente tenham uma uniformidade que os da cidadania não têm, porque lida com saúde pública, cadeias públicas, coisas tão diferentes que tornam o trabalho de coordenação muito mais precário." (F)

Como antes de 1993 os CAOs tinham funções de execução, os promotores que participaram das primeiras questões envolvendo direitos coletivos, e que hoje estão atuando nas Promotorias da Capital, já não solicitam muito apoio operacional, o que faz de tais centros uma referência muito mais presente para as Promotorias do interior.

"Há um apelo quase total por parte do interior, porque lá o colega não é promotor só da cidadania, mas também do meio ambiente, júri, e tudo o mais. Como conseqüência, ele não consegue se atualizar o tanto que seria necessário para atuar em todas essas matérias, então ele demanda muito mais do CAO. Muitos dos recursos de que os colegas do interior precisam estão na Capital, os órgãos como, por exemplo, o Tribunal de Contas, enfim, tudo. Alguns colegas do interior são ão especializados quanto os da Capital, mas por decisão própria, mas nas outras áreas eles pedem muito apoio. Já a Capital solicita muito pouco, porque como eles trabalham unicamente com isto, eles têm condições de se especializar, e portanto não precisam tanto do CAO." (F)

Enquanto os CAO do Meio Ambiente e do Consumidor se desenvolveram em termos de atuação macro-estratégica, voltados à captação e interpretação de dados externos, o CAO da Cidadania tem uma atuação mais voltada a atender demandas internas de suporte aos órgãos 
de execução.

"O CAO pode elaborar estratégias a partir da macrovisão detectada pelos problemas comuns, mas aí ele deve chamar os promotores para então discutir em conjunto uma orientação para o assunto. O CAO do meio ambiente faz assim, e em menor grau, o do consumidor também. O CAO da cidadania é complicado porque abrange tudo que não é dos outros. Basicamente, é tomado pela defesa do patrimônio público e pela repressão à improbidade administrativa, ficando todos os outros aspectos da cidadania, educação, saúde, transporte, tudo, em segundo plano. Além disso, é um CAO ainda novo, que precisa chegar ainda a uma estrutura como a do meio ambiente, por exemplo, que é bem anterior." (I)

Apesar de situado na cúpula e de se constituir de cargos de confiança, portanto de caráter político, o funcionamento do Centro de Apoio Operacional da Cidadania ainda não dispõe, ao menos no que se refere ao direito à saúde, de força suficiente para direcionar macro-estratégias institucionais, podendo-se mesmo afirmar que reproduz a atuação atomizada que se verifica na base, limitado que está aos procedimentos que lhe são comunicados.

"A informação é trabalhada basicamente de forma gerencial, servindo também para orientar quem precisar aproveitar experiências que deram certo. Como as informações são catalogadas, é possível encontrar casos semelhantes àqueles com que o promotor se depara. Agora, o CAO depende daquilo que lhe é comunicado. Se não há comunicação, não há como saber o que está acontecendo nas Promotorias. E há por aí uma interpretação de que não é preciso comunicar o CAO das representações, apenas dos inquéritos e das promoções de arquivamento. Como o CAO não pode impor a sua orientação, ele acaba se distanciando de quem não o mantém informado." (F)

"Esse é um dos problemas institucionais que se liga um pouco à cultura jurídica nossa que é um tanto compartimentalizante. No MP, acho que o centro de apoio poderia ser uma experiência muito mais produtiva do que está sendo; já participei de um centro de apoio, e acho que o problema é que ninguém sabe o que fazer no centro de apoio, ou talvez não saiba exatamente qual é a função que se espera do promotor que está lá, há uma crise de identidade muito forte. Acaba sendo um apoio no pior sentido possível: disque-SOS. Quando eu trabalhava em centro de apoio, ficava maluco, porque não adiantava querer fazer uma análise de um assunto qualquer que fosse, porque tinha que parar quinhentas vezes para atender telefonema de colegas querendo trocar impressões sobre cada caso. Os centros de apoio são assim em geral, o do meio ambiente tem sido melhor, que tem começado a introduzir uma proposta com resultados. Acho que a gente só vai conseguir unificar qualquer coisa que seja, consumidor, cidadania, meio ambiente, crime ou cível, 
se a gente trabalhar com resultados esperados. Para se ter um trabalho sério em saúde, por exemplo, tem que ter claro qual é a situação da saúde pública hoje, como é que se pode intervir nesse quadro, quais os resultados buscados. É preciso ter um plano estratégico, na área de meio ambiente talvez isso esteja mais fácil, por exemplo, no caso da Mata Atlântica, em que se sabe a cobertura florestal, qual a meta de recuperação em quanto tempo. O centro de apoio de meio ambiente, sim, tem sabido direcionar essas questões, o que já não acontece nos demais, que acabam sendo centros meramente burocráticos. A função do centro de apoio seria acompanhar as políticas da área, até para poder gerar a própria política institucional, monitorar as demandas, a atuação dos órgãos concorrentes, dos vários agentes, executivos e legislativos, para poder estar dominando a informação de que necessita. Nisso é que vai a diferença entre trabalhar com iniciativa ou mediante estímulo externo. Se se tem um quadro geral em que se sabe onde se quer chegar, os esforços são direcionados, ao menos prioritariamente, de acordo com aquilo; senão, a sua atuação vai ser determinada por aquilo que cai no seu protocolo."

\subsection{Dificuldades conceituais e operacionais}

Uma vez conhecidos o encaminhamento de demandas e macro-estratégias institucionais, entendem-se alcançados os objetivos instrumentais descritivos. A partir deste ponto, dedica-se o estudo à consideração das dificuldades percebidas pelos membros do MP no cumprimento da função específica de zelar pelo direito à saúde.

"Existem muitas questões em que temos ainda que discutir se podemos atuar, e se podemos, como, porque o Judiciário pode pensar diferente, pode pensar que não. Ou seja, tudo isto está em construção." (F)

"O que eu senti, num primeiro momento, foi um certo estarrecimento com essa norma, o que fazer, o que ela significa, como lhe dar conteúdo. O primeiro passo disso, que acho que já está bem consolidado, foi a questão da legitimidade: o que podemos ou não podemos fazer. Hoje a questão está muito mais centrada em como fazer o que já sabemos que podemos fazer. Existe ainda uma dificuldade bastante grande no MP quanto ao instrumental jurídico, especialmente processual e judicial para efetivar essa atribuição na defesa dos direitos constitucionais do cidadão e serviços de relevância. Eu acredito que o grande obstáculo disso tem sido, num primeiro ponto, a questão das ações mandamentais, como elas de uma maneira geral se viabilizam em nosso sistema jurídico, em nosso sistema judicial; e num segundo ponto, como que essas ações judiciais, os provimentos mandamentais, se viabilizariam contra a Fazenda Pública, matéria ainda muito controvertida. De alguma forma, esse ainda é o grande impasse com que se depara o MP, 
que vai ter que tomar pulso no andamento disso para conseguir extrair um posicionamento da nossa magistratura sobre a questão das possibilidades desse tipo de ação. Nós trabalhamos com dois grandes entraves contra os provimentos tipicamente mandamentais, que s̃o os dogmas da intangibilidade da vontade individual, segundo o qual o Judiciário não poderia impor medidas de fazer ou não fazer contra a vontade do agente, e o segundo dogma, da separação dos Poderes. Dos dois lados eu acho que são princípios já bastante corroídos pela realidade atual de todo Estado contemporâneo. Seja porque o Estado em si se tornou muito mais regulamentador da atividade privada, notadamente da atividade econômica, e com isso mais invasivo das esferas individuais, seja porque o Estado, nessa própria função, mudou de uma função passiva de garantidor da liberdade negativa do cidadão para uma liberdade positiva, que implica sempre num fazer, num participar, num conceder de benefícios e tudo o mais. Eu acho que o reflexo dessa mudança já sentida no Estado, que ainda não está consolidada no Judiciário, tende a entrar pela via dos direitos difusos e coletivos, até por serem difusos e coletivos, porque tendem a levar para o Judiciário uma nova pauta de questões com muitas implicações quanto ao próprio papel e ao próprio modo de atuação do Judiciário. Eu acho que esse tipo de assunto ainda não chegou, continua-se a trabalhar muito num patamar de separação de Poderes extremamente estrito, e que concebe a sociedade como uma interligação de sujeitos individuais, de autonomias pessoais." (G)

O fato de se ter tamanha clareza sobre as dificuldades teóricas trazidas com os direitos metaindividuais evidentemente não as exclui, antes as torna ainda mais complexas se somadas à especificidade de cada um desses direitos.

Questões envolvendo conceitos de legitimidade para agir e discricionariedade da administração, para citar apenas dois exemplos recorrentes no discurso institucional, encontram divergências no interior do próprio MP. No entanto, todas as posturas convergem para um mesmo ponto: o Judiciário ainda não se convenceu.

"Entre os colegas, há muita clareza dessas dificuldades. Divergências há com o Judiciário e evidentemente com a parte contrária. O Judiciário não tem uma formação de direito público para entender certas coisas como essa. Existe discricionariedade, mas isso não pode significar o desprezo da realização de atividades que o Estado tem que fazer. O Judiciário ainda precisa de uma construção sobre isso, que não sei ainda quantos anos vai levar." (I)

"Se a gente tem informação de um problema, ainda que seja por contato telefônico, procura administrativamente resolver o problema, porque ir a juízo, chegamos à conclusão que é mais complicado ainda. É a falência do sistema. O Judiciário está num 
ponto em que ou ele reage, ou ele afunda e eu não sei o que vai ser de nós. É uma via já prejudicada. O que vai para o Judiciário não tem resposta satisfatória: depois de muitas ações civis públicas que não deram em nada, acabamos percebendo que a via judicial deve ser a última da última da última instância. Embora o Judiciário devesse ser o meio mais comum de atender os direitos do cidadão, se eu tiver a preocupação de proteger efetivamente o direito, não vou usar o processo judicial. É preciso fazer uma opção - até já se discutiu isso teoricamente, mas prefiro deixar a teoria de lado, porque quero saber da efetiva, da concreta proteção do direito. Em alguns casos, levar a causa ao Judiciário pode até atrapalhar o exercício do direito. As ações civis públicas propostas pelo MP nesse assunto ainda não chegaram no segundo grau. As ações demoram muito e as ACPs de um modo geral, sobre qualquer assunto, se não forem extintas logo de cara (o que é o que mais acontece --- costumo dizer que tenho coleção de derrotas, por ilegitimidade, falta de interesse de agir, incompetência disso e daquilo, enfim, todas as falhas processuais que eles puderem apontar, eles apontam), não tem nunca o mérito reconhecido. A coisa tem mudado de uns três anos para cá, porque hoje há juízes mais sensíveis que não fogem de uma $\mathrm{ACP}$, falando Português bem claro. São ações muito complicadas, muito pesadas, o juiz precisa ter uma capacidade de administração, de imaginar que aquilo vai se lançar no futuro, ele não vai conseguir resolver o problema num ato só, porque todas essas ACPs trazem questões que vêm há muito tempo conduzidas de forma errada, por falta ou aplicação adequada de políticas públicas. Então, não é um passado que se possa resolver aqui, com perdas e danos, mas é preciso organizar o futuro e hoje o juiz não pode fazer isso: nem o processo civil hoje como existe está concebido para isso, e também não tem a formação para isso, nem o vício da atividade deixa o juiz pensar desse jeito. Esta é uma dificuldade de mentalidade e de formação, por isso as ações demoram tanto a chegar no segundo grau e quando chegam, portanto, é claro que o juiz de segundo grau tem muito menos condição de avaliar uma ACP que o juiz de primeira instância. Na Justiça Federal, por exemplo, voltada predominantemente para a matéria tributária ou de ordem previdenciária, aquelas ações que se repetem à exaustão, se o juiz que tiver 7.000 processos, talvez com um voto ele resolva 280 processos. A estrutura do gabinete dele vai funcionar para resolver tudo que for padrão, então as ações diferenciadas, como as benditas ACPs, são deixadas de lado, e para tramitar... Na segunda instância, se não caírem com um juiz relator que converse, o melhor é esquecer o assunto. Mas o mais difícil mesmo é chegar no STJ, porque às vezes há julgamento e o colega que atua no segundo grau não recorre da decisão. De novo, a tal da independência: o outro propôs a ação, mas eu penso diferente e não vou recorrer. Então a dificuldade é fazer com que as ações do primeiro grau consigam chegar no STJ, por exemplo; no Supremo, então... surgiu uma ação há pouco tempo, cuja matéria era 
flagrante, envolvendo mensalidades escolares, da qual não dava para escapar e seguiu, teve sentença de procedência, oTribunal reformou a sentença, dizendo que o MP não tinha legitimidade, e isso foi para o Supremo. Essa foi a primeira ação que chegou ao STF para falar da legitimidade do MP; mas oacórdão é de 1997, quer dizer, temos ACP há doze anos e esta é a primeira vez que o STF decide na matéria de legitimidade do MP para propor ações envolvendo interesses individuais homogêneos. Mas acredito que o Judiciário vá mudar, porque hoje temos juízes muito sensíveis a esse tipo de demanda que vão eventualmente substituir no Tribunal, e durante a substituição resolvem o assunto." (D)

Esta expectativa centrada na última instância do sistema de justiça, como que esperando dela uma interpretação final dentre as várias possíveis --- o que talvez se atribua a uma formação excessivamente dogmática ---, pode explicar porque a atuação extrajudicial do MP é ainda reticente se comparada à sua atuação judicial, apesar de os entrevistados todos declararem o contrário (há que se considerar que mesmo todas as soluções extrajudiciais alcançadas pela atuação individualizada certamente não comportam a totalidade dos conflitos que poderiam ser solucionados preferencialmente por essa via). Pode-se ler nisto um bombardeio de argumentos que forcem os juízes a 'dizerem o direito' quanto ao próprio papel do Ministério Público, não à toa designado como o Quarto Poder, ${ }^{23}$ nem sempre reconhecido como legítimo, porquanto excessivo, sendo censurado por abusar do instrumental que tem em mãos, ultrapassando os limites de suas atribuições.

"Sempre é o interesse público a causa legitimante do Ministério Público e a referência a ele numa disposição específica do Código de Processo Civil (art.82, inc.III) constitui autêntica norma de encerramento do sistema, destinada a prevalecer em casos não previstos especificamente, arredios a previsões e insuscetíveis de generalizações. Daí o grande erro no entendimento de que tal dispositivo conduza à legitimação do Parquet para todas as causas em que seja parte a Fazenda Pública (além do mais, o Ministério Público não é fiscal dos interesses fazendários)." 24

Este é apenas um exemplo dentre os muitos que se poderia citar, até porque --- como se procurou demonstrar e se pode verificar nos Anexos ---, as matérias de saúde submetidas à atuação do MP estão longe de se restringirem às questões patrimoniais.

Outra questão a merecer destaque é a imbricada descentralização do sistema de saúde, em que se desenha um federalismo de cooperação extremamente complexo, dados os variados 
níveis de atenção à saúde e o entrecruzamento de competências executivas e de polícia administrativa. Esta questão evidentemente se fez sentir no interior da administração do SUS, tendo redundado em Normas Operacionais Básicas (NOBs) em 1991, 1993 e 1996, que, "a partir da avaliação do estágio de implantação e desempenho do SUS, se voltam, mais direta e imediatamente, para a definição de estratégias e movimentos táticos, que orientam a operacionalidade deste Sistema." Assim, visando promover e consolidar o pleno exercício, por parte do poder público municipal, da função de gestor da atenção à saúde dos seus munícipes, com a conseqüente redefinição das responsabilidades dos Estados e da União, avançando na consolidação dos princípios do SUS, foram construídos modelos distintos de gestão (plena de atenção básica e plena do sistema municipal) e redefinidos os papéis dos gestores estaduais e federal, criando-se uma série de mecanismos de mediação e integração do sistema, em que se destacam as instâncias formadas pelos gestores municipal, estadual e federal - a Comissão Intergestores Tripartite (CIT) - e pelos gestores estadual e municipal - a Comissão Intergestores Bipartite (CIB). ${ }^{25}$

É interessante notar que, ao identificarem as questões relativas à distribuição de competências, nenhum dos entrevistados deu mostras de familiaridade ou mesmo de qualquer reconhecimento de avanço a partir de tais NOBs, não che gando sequer a mencioná-las:

"Depois que começamos a nos organizar, separar os assuntos e levantar os problemas, vimos que a coisa era muito maior do que se imaginava, que não tínhamos ainda o menor preparo técnico para lidar com as questões, nem de como funcionava a administração, nem mesmo da área jurídica, da legislação, porque não era só uma lei, eram leis, portarias, resoluções, pareceres normativos, uma coisa atrás da outra, uma hora tinha convênio, depois se mudava o convênio, que era ampliado, ou não era. Nós nunca tínhamos parado para pensar nesses assuntos, até descobrir que era um cipoal de convênios e convênios, um que emenda com outro que omite alguma coisa, que remete ao seguinte, depois continua valendo o anterior, soluções administrativas não muito sustentáveis, o que fazia dos problemas aquela bola de neve crescente. " (D)

"Um problema legislativo que eu vejo é o seguinte: a competência legislativa em saúde é concorrente. Esta difusão da competência é salutar, só que não há fronteiras bem definidas sobre o que cada esfera pode legislar. Aí vem a competência material, ou executiva, que é comum, que é uma grande idéia, mas é preciso definir cada uma das competências, senão vai embaralhar tudo, porque ou ninguém presta determinado serviço,

\footnotetext{
${ }^{25}$ NOB/96 (Portaria MS n ${ }^{\circ}$ 2.203, publicada no D.O.U.de 6/11/1996).
} 
ou os três prestam ao mesmo tempo. A ideologia do SUS era permitir que uma pessoa pudesse ter atendimento em qualquer lugar, universalmente. Mas para isso é preciso melhorar a distribuição de competências entre as três esferas.

Outro problema é o da execução das políticas. Apesar da Lei 8.080/90 ter uma boa redação nesse sentido, ela se perde muito em princípios muito amplos, e nós sabemos que a discricionariedade administrativa é um grande instrumento na mão de um bom e de um mau administrador. E esse problema sempre é levantado quando se discute o art.129, II. A evolução da doutrina e da jurisprudência é no sentido de diminuir o foco da discricionariedade, e por isso a nossa Constituição é tão dirigente como é. Vi outro dia uma proposta do Ministro da Saúde que é a mesma que se fez na educação: a atribuição de um patamar mínimo de despesas a ser estabelecido em lei, vinculando uma parcela da arrecadação dos impostos. Não vai haver muita efetividade se a lei contiver conceitos muito indeterminados." (I)

Essa dificuldade relacionada à distribuição de competências vem inevitavelmente associada a outra, relativa às possibilidades de litisconsórcio ativo entre o MPF e o MPE, assunto que deixa também transparecerem sérios problemas operacionais de comunicação:

"Acho que seria necessário superar uma desonestidade conceitual que há em torno da autonomia do Estado. Nossa federação é meio maquiada, porque somos um Estado unitário com aparente forma de um Estado federativo. Para sermos honestos, seria preciso assumir que o grosso dos recursos da saúde não está a cargo exclusivamente do Estado ou do Município, vem da União. Enquanto a distribuição de verbas estiver desse jeito, não dá para fugir desse federalismo cooperativo meio manco. Portanto, desde que haja a intervenção de recursos predominantemente da União, não dá para escapar da competência da Justiça Federal, que deveria chamar as ações que tramitam na Justiça Estadual. Algumas questões que envolvam política doméstica são bem complicadas de serem trabalhadas no Estado, o que deveria ser atraído para a esfera federal. Esse é um fato que não dá mais para esconder e acho que já é até assumido." (D)

"Não há muito fluxo de informações sobre o que uns e outros fazem, o que em muitos casos pode até ensejar ações nas duas esferas, e a gente às vezes até se pergunta se não há já alguma litispendência, principalmente em se tratando de recursos do SUS para o FUMDES. Agora, ou a competência é muito bem estabelecida no que toca à Justiça Federal, se houver interesse da União, ou fica conosco, e daí resulta uma compartimentalização. Não é como nos Estados Unidos, em que a Justiça Federal e a Estadual são em grande parte concorrentes, o que causa esse efeito em escala bem maior. Mas é verdade que há áreas bem nebulosas e na área da saúde, especificamente, como o SUS não funciona, acaba não funcionando também uma eventual integração do MP, 
porque, se em princípio o SUS deveria ser uma estrutura coordenada entre as várias instâncias do poder, isso definiria muito o contato entre o MPE e o MPF. Como na verdade o SUS não funciona dessa forma, não está lá muito bem dividido, acho que cada um está mais preocupado com o que não vai fazer. Eu tenho a impressão que na saúde vai se fazer o que se fez agora na educação, na LDB. Ensino elementar, secundário e superior são atribuídos de forma clara para cada uma das esferas." (G)

"Não há um canal de informações, isso vai muito do contato pessoal. Se a questão for analisada cruamente, a Constituição separa claramente: nos casos que envolvem a União, MPF, no resto, MPE. Mesmo que tudo envolva verba federal, o Supremo decide, e já decidiu nos dois sentidos. Há na verdade uma falta de critério seguro, então, quando estamos investigando alguma coisa, é porque acredita que a competência seja nossa, mas o MPF também pode achar que é competência dele. Por exemplo, o MPF nos enviou uma cópia da instauração de uma investigação que estão fazendo sobre os bancos de sangue, e ficamos nos perguntando porque é que isso estava com eles, porque afinal de contas a União só coordena, a fiscalização é estadual, não tem absolutamente nada a ver com a esfera federal. Agendamos uma reunião que acabou não acontecendo e ficou por lá mesmo. Agora, não sei o que vão fazer com aquilo." (F)

"Com todo respeito aos colegas, o MPF às vezes força um pouco a barra. Por exemplo, ontem mesmo um Procurador da República noticiou que foi a juízo por conta das ações da Telebrás. Um promotor do direito do consumidor aqui da Capital já tinha entrado com uma ação igualzinha, só que ele não obteve liminar. Aí o Procurador da República, usando os mesmos argumentos, causa de pedir, tudo igual, obteve liminar na Justiça Federal. Aí gerou litispendência. Jogou na Justiça Federal porque fez a União Federal figurar como réu, mas não é bem assim, aí atrasa o que já estava sendo feito. Outro exemplo: o MPF entrou com algumas ações civis públicas sobre publicidade, que foram rejeitadas liminarmente justamente porque o juiz não reconheceu que a competência era federal só sob o argumento de que a publicidade invade o território de mais de uma unidade da Federação. AConstituição é muito clara no art.109: são de competência da Justiça Federal os feitos em que a União é parte ré ou é parte autora, assistente, litisconsorte etc. Não há outra razão. Então o MPF faz um monte de coisas que não devem fazer, acabam duplicando o nosso serviço, e tem coisas que eles devem fazer e não fazem. Já há necessidade de um órgão a nível nacional responsável pela dirimição de conflitos entre MPs. O Judiciário já deu até uma decisão em que ficou claro que isso não é problema dele, como se dissesse 'vocês que se entendam', alegando que conflito de atribuição administrativa não pode ser dirimido judicialmente. Agora, se houver litispendência, vai para o STJ, mas isso vai levar uns quatro anos para ser decidido. Nesse 
caso da Telebrás, por exemplo, a única diferença na relação processual jurídica como um todo é que o Procurador da República jogou a ação para a União também, e o MPE, não. Poderia até haver um litisconsórcio entre os dois MPs, como foi feito uma vez no caso do leite. Há algumas ações em conjunto, mas muito poucas. Nós já tentamos, mas o MPF é muito distante, eles se acham muito superiores e não são. No caso do leite que veio de Chernobyl foi uma dificuldade, eles são cheios de detalhes, cheios de dedos, enquanto estava todo mundo reclamando, jornais bombardeando exigindo uma atitude, aí quem acabou fazendo praticamente tudo foi o MPE. Como há uma súmula expressa no sentido de que a competência é da Justiça Federal quando fosse ré a Cobal, entramos em contato com o Procurador da República Chefe aqui na ocasião, totalmente despreparado para esse tipo de coisa, que acabou propondo que a gente instaurasse o inquérito e eles também acompanhassem. Foi designada uma pessoa de lá, mas a gente fazia e ela só assinava. Agora, por exemplo, no caso do PAS, essa questão do repasse de verbas federais, deslocando o assunto para a esfera federal, é irrelevante. Se o MPE fosse omisso, até seria admissível essa argumentação, que não é lá muito jurídica, até serviria como pretexto para suprir o que a gente não estivesse cobrindo, mas não é o caso. Além disso, a questão do repasse de verbas é para ser discutida no âmbito do patrimônio público, não da defesa do cidadão. Para o cidadão pouco importa de onde vem o dinheiro, o que ele quer é ser atendido condignamente, com segurança, eficiência." (K)

"A rigor, seria bom que os MPs fizessem esse tipo de avaliação, sobre as competências entre esfera estadual e federal, antes que isso chegasse aos tribunais superiores na forma de conflito. Há ainda uma coisa que eu acho meio infantil que é a disputa por espaços em alguns assuntos, não há ainda um diálogo muito aberto. Há alguns convênios celebrados de atuação conjunta, mas que ficaram muito mais na intenção que verificados na prática. Tive alguns casos de matéria ambiental, e o que eu queria era resolver o problema, não entrar em discussão sobre quem ia ingressar com a ação. Devia era haver uma avaliação estratégica conjunta sobre a resistência da Justiça Estadual ou da Federal nessa ou naquela matéria, para saber onde haveria mais chances de êxito. Como a lei prevê o litisconsórcio ativo, poderia ser mais utilizado, mas ainda há muita resistência, acho que mais por parte do MPE. Claro que há colegas que isoladamente tem relações até de amizade, que vem do tempo de escola, de faculdade, que facilita o diálogo, mas não há uma decisão, embora haja convênios de cooperação, sobre esse tipo de avaliação sobre onde é melhor ajuizar a ação." (M)

"Verdade seja dita, essas hipóteses de litisconsórcio, embora tenham grande potencial de importância, principalmente em questões que excedam os limites territoriais de uma comarca ou até mesmo de um Estado, ainda são usadas excepcionalmente, porque tem 
faltado uma política mais elaborada de atuação conjunta. Hoje, essas hipóteses de atuação conjunta dependem mais da iniciativa isolada e pessoal dos membros envolvidos, e não de uma política institucional a respeito. O primeiro caso concreto de atuação conjunta entre o Ministério Público estadual e o federal ocorreu aproximadamente há mais de uma década, na proibição da comercialização do leite contaminado de Chernobyl." (E)

Desencontros como estes levam a crer que os princípios de unidade e indivisibilidade tem perdido espaço para o da independência funcional na prática diária da instituição, dificuldade que se nos apresenta como a mais aguda, a comprometer a imensa missão de conduzir a sociedade a padrões mais justos de convivência. Ao contrário do que se possa imaginar, esse problema não se circunscreve à interação intra-ministerial, mas se faz refletir no contato externo com outras instituições, o que se torna tanto mais grave quando se trata de atuarem conjuntamente o Sistema Único de Saúde, meio de execução de um direito constitucionalmente garantido, e o Ministério Público, meio de controle dessa garantia.

"Uma vez participei de um evento sobre redução de dano na distribuição de seringas, em que o Secretário de Saúde manifestou que na visão da Secretaria, a relação com o MP era a seguinte: ou a gente sai da frente, ou corre atrás. Ou seja, o MP não é visto como parceiro, mas como um bando de gente que atrapalha, que não sabe nada e que vem querer dizer ao outro profissional o que ele deve fazer. Para se ter uma idéia, há uma semana houve um evento sobre um consórcio entre Prefeituras, e um dos painéis era sobre a atuação do MP. Estavam lá vários prefeitos e foram alguns promotores para discutir isto e, embora algumas questões importantes tenham sido colocadas --demonstraram que gostariam de uma parceria e tal ---, mas o principal foram reclamações do MP, algumas até pertinentes. O fato é que eles vêem a gente como aquele que quer perseguir o Executivo, e não como alguém que toma a lei como critério. Que o cidadão não tenha clara qual a função do MP, ainda se compreende, mas não um chefe do Executivo. Isso atrapalha muito, porque dificulta que eles nos vejam como parceiros." (F)

"Usando de toda honestidade, muitas vezes, a gente se vale da ignorância do outro lado, sem saber até que ponto podemos ir, blefando no sentido de ameaçar com a propositura de tal e tal ação, que no final sabemos que não dá em nada. Mas para a outra parte, que não sabe muitas vezes nem qual o papel do Ministério Público, é o quanto basta para resolver o problema administrativamente. Às vezes, o problema surge por absoluta ignorância também do servidor, não por má fé, apenas por ter sido ensinado a fazer daquela forma, que fazia sem questionar, então dá tempo para corrigir. E se por acaso, fazia por desídia, via que podia acontecer alguma coisa, então corrigia por conta própria. Assim, administrativamente, quando há uma vontade do funcionário de compreender e 
fazer, acontece." (D)

"O CVS não quer fiscalizar a saúde pública. Tenho até séria desconfiança do porquê eles não querem. É impressionante a má vontade, a quantidade de vícios desse setor da vigilância de serviços médicos e hospitalares, que eu tenho impressão são bem difíceis de serem superados. Acho que eles estão acostumados a fiscalizar entidades privadas e desconfio de alguma relação promíscua aí entre fiscalizados e fiscalizadores. Para conseguir que eles fiscalizem alguma coisa do Município ou do próprio Estado é uma loucura. Por isso é preciso ter peritos aqui. Acho que os nossos problemas estruturais são de duas ordens: primeiro, o MP cresceu e foi formado numa cultura em que a sua atuação era uma atuação gratuita, quer dizer, o processo judicial vinha para a sua mesa de graça -antigamente nós não tínhamos nenhum funcionário, então vinha de graça mesmo, porque era o funcionário do cartório do Judiciário que trazia e levava o processo --, nem o papel a gente gastava, porque se manifestava muitas vezes no papel do próprio Judiciário; a mesma coisa na atuação criminal, porque o inquérito policial vinha para a sua mesa de graça, porque a polícia é que trazia, quando precisava de alguma diligência, pedia para a polícia, que é quem acaba realizando as atividades custosas, perícias e tal, então o MP se criou trabalhando de graça e se acostumou a isso. Quando surgem essas novas atividades de direitos difusos e coletivos, de proteção de interesses sociais, e que o MP tem para si, além do poder de iniciativa, o poder de investigação, surge um grande problema, porque as coisas não são gratuitas, realizar perícia custa dinheiro, realizar uma auditoria, que é necessária em muitos casos que envolvem o patrimônio público, custa muito dinheiro, o conhecimento necessário para determinadas áreas é muito específico e muito caro. Acho que não dá para o MP achar que ele vai conseguir ter um quadro completo de peritos, porque não vai. Sempre vai haver aquele caso que exige uma especialização tal que os peritos do MP não vão saber fazer, que é o que já acontece em muitos casos. Precisa acabar com essa bobagem de que a gente pode trabalhar de graça, ou de que a gente precisa construir uma burocracia própria para fazer essas perícias. A gente precisa é ter dotação orçamentária para contratar essas perícias, seja de entidades públicas, seja de entidades privadas, porque também é uma ilusão achar que dá para chegar lá na USP ou qualquer órgão que seja e que eles vão fazer de graça, porque são recursos deles. Eu já tive casos de meio ambiente que envolviam custos laboratoriais, enzimas, neutralizantes, isso e aquilo, e esses recursos estão voltados para atividade de pesquisa, então não é possível deslocar pessoal e recursos para atender o MP. Então, precisava ter essa dotação para patrocinar esse tipo de serviço. Com relação a outros órgãos públicos, de fiscalização, acho muito complicado depender deles, porque são nossos possíveis réus, essa que é a verdade. Infelizmente, o serviço público, notadamente na área da saúde está 
contaminado, é difícil você achar um profissional da saúde, um médico, que não se beneficie do próprio sistema, que permite que ele acumule muitos empregos públicos e privados, sem dar muita atenção principalmente aos públicos. Portanto, é muito difícil você contar com isso. Para se ter uma idéia, uma experiência que acho muito bem sucedida, pena que foi logo anterior ao PAS e depois o PAS mudou e essa avaliação meio que se perdeu, foi a do MPF que, através de uma auditoria do SUS, fez uma avaliação do sistema municipal de saúde. Para fazer avaliação médica, foi preciso trazer médicos de outro Estado, porque não conseguia médico confiável dentro do Estado de S.Paulo que fizesse. Então, isso tudo se resume a recursos. Não se trata de mordomias, mas de reconhecer que o nosso trabalho é custoso, principalmente para mexer com interesses que são coletivos, grandes, que têm na ponta a contraposição de interesses econômicos muito poderosos." (G)

Essas dificuldades de ordem operacional, principalmente no que se refere a recursos humanos, antes de alertarem justamente para a necessidade de trabalho próximo às instituições dotadas de conhecimento especializado, são apontadas como falhas a serem corrigidas por meio do incremento de quadros. Além disso, parece haver uma desconfiança apriorística com relação aos órgãos do Estado incumbidos da fiscalização, sem que um potencial trabalho conjunto com o MP seja vislumbrado como fator de inibição das práticas censuráveis. Embora o problema seja comum a todas as Promotorias, mais uma vez, são os setores mais especializados que tomam a vanguarda na forma de encará-lo:

"Um dos aspectos que a Promotoria identificou como prioridade foi a busca de um bom parceiro na administração direta. A Secretaria do Meio Ambiente passou por uma fase em que não estava aparelhada adequadamente e com menos material humano disponível. As condições para exercer a fiscalização direta diminuíram e percebemos que isso estava causando um problema sério em termos de tutela geral. Neste caso, a atuação da Promotoria é prospectiva, no sentido de buscar, de estimular, através da atuação ministerial, a administração pública a cumprir melhor a sua tarefa. Nesse sentido temos um exemplo muito importante que é o da área de mananciais. Alguns órgãos da administração pública direta estavam firmando um entendimento no sentido de que não teriam a atribuição de impor medidas de punição administrativa. Ela podia até detectar os problemas, mas chegava a uma situação de impasse: não atuava mais porque não impunha penalidades. Com a atuação da Promotoria na questão das áreas de manancial, provocando a administração, oficiando o próprio secretário, buscando manifestação do departamento jurídico de assessoria da própria Secretaria, eles passaram então a estudar para descobrir maneiras de mudar esse entendimento. Isso foi importantíssimo. Quando 
se estabeleceu melhor a abrangência do poder de polícia administrativa, se criaram condições para a atuação mais eficiente da administração pública em certas atribuições na área do meio ambiente, que o Estado chama para si e que são rotineiras.

$\mathrm{Na}$ verdade, falta apoio técnico a todas as Especializadas. (....) há uma lista de procedimentos paralisados, esperando sempre que algum órgão técnico estatal nos atenda, demorando por vezes vários meses. Quando o empreendedor é o próprio Estado, você vai pedir um laudo de um órgão público sendo que ele é o próprio degradador ambiental? Eu preciso ter um técnico independente. A Procuradoria-Geral poderia fazer o que está fazendo para outras áreas, como a contábil, de administração e até engenheiros de tráfego. Mas, na área de engenharia florestal, na área de biologia, enfim, em outras áreas ambientais, não temos ainda técnicos concursados para trabalhar na área. É urgente e imperioso que o MP encontre uma solução eficaz para essa questão. Não temos a solução pronta. Estamos falando de um problema que atinge todas as Promotorias, que têm enfrentado sozinhas essa carência de apoio técnico na sua própria operação. Alguma maneira institucional de enfrentar essa questão teria de ser pensada, ainda que não seja pela contratação formal, mas sob uma forma de prestação de serviços. Uma forma seria através de convênios com universidades, que dispõem de todas as áreas de conhecimento necessárias e que estão aí para isso, já que este é o seu papel. Se pensarmos em quais os profissionais que deveríamos ter na área ambiental, relacionaríamos mais de trinta: todos os graus de conhecimento que a gente imagina ser necessário, geólogos, geógrafos, engenheiros sanitaristas etc. Já foi tentado um convênio com a Universidade de São Paulo, mas parece não ter dado resultado pela falta de verbas. Os recursos são essenciais." 26

Se o que o Ministério Público pretendia ao envidar esforços para que a Constituição lhe reconhecesse o papel social que hoje lhe é exigido era oferecer mais uma porta de acesso à justiça à sociedade, é preciso que esteja pronto a receber as mensagens que esta lhe envia não apenas pelos meios que o próprio MP julga os mais adequados, mas por todos os meios possíveis. Neste sentido, foram detectadas pelo menos três atitudes que afastam a instituição de seus propósitos, como se comenta a seguir.

A primeira diz respeito à recepção de relatos trazidos voluntariamente por potenciais representantes que se intimidam diante da necessidade de se identificarem. Esta questão não havia sido sequer suspeitada antes que um incidente durante a coleta de dados a fizesse emergir. Depois de cumpridas as formalidades que autorizassem o acesso às dependências do

\footnotetext{
${ }^{26}$ Entrevista com Promotores do Meio Ambiente. Revista da Associação Paulista do Ministério Público, Ano I, nº 9, Agosto de 1997, pp.6-9.
} 
MP para a pesquisa, que no MPF chegaram a constituir procedimento administrativo de que constaram cartas de apresentação e comprovantes do vínculo universitário, solicitaram-se dados como telefone e endereço pessoais, o que mais tarde foi justificado por equívocos gerados em cartório, uma vez que esta seria a praxe dos oficiais quando reduziam declarações a termo. Esta ocorrência aparentemente sem maiores efeitos suscitou uma curiosidade incluída no rol de perguntas a serem formuladas durante as entrevistas. Eis o resultado:

"Em princípio, não se recebe a denúncia sem que a pessoa se identifique. Para isso, é preciso uma ação do Procurador, em face da relevância. No caso do dossiê Chamone, por exemplo, havia denúncias anônimas. O normal seria não receber, mas como há por trás vários elementos importantes, então a gente investiga. $\mathrm{O}$ fundamento para não receber está na possível manipulação do MP, pela insegurança que isso possa gerar, pela perda de tempo -- há muito maluco que aparece o tempo todo fantasiando com relatos absurdos... A não ser que a gente perceba que há uma razão para a pessoa não se identificar. Existe uma ordem de serviço no sentido de que o depoente deve se identificar. A gente não divulga os dados para ninguém, mas o feito é público. O que acontece na maioria das vezes é que a pessoa faz uma denúncia formal daquilo que ela se sente à vontade para falar, e depois ela vem solicitar ao Procurador para ouvir, sem registrar, aquilo que a faz se sentir intimidada, e então o Procurador avalia se deve ou não ceder a isso, conforme a situação. Em tese, não deveria, mas às vezes é muito mais produtivo simplesmente ouvir. Isso é uma coisa com a qual já se conta: o depoente se certifica de que o depoimento está encerrado e aí pede para contar mais isso e aquilo. Todos os Procuradores são sensíveis a uma pessoa que esteja querendo falar e não encontra guarida, se ela diz que não pode se identificar porque tem o medo de retaliação, na mesma hora vai ser atendida, não pelo técnico, pelo Procurador, mas é preciso ter um mínimo de elementos para fazer uma filtragem institucional. Onormal é que a pessoa se identifique, que seja tudo muito formal, mas isso comporta exceções, acho que todos os Procuradores sabem da importância de proteger o depoente, ou seja, a exceção também é regra, acho que todos pensam da mesma forma: entre não ouvir e ouvir sem registrar, acho que quase todo mundo prefere ouvir." (B)

"As pessoas têm medo quando o assunto é criminal. Quando é tutela coletiva, não. As pessoas não demonstram medo em se identificar. As denúncias chegam aqui quando as pessoas percebem que há alguém da administração envolvido. Agora, as denúncias comuns vão parar na delegacia de polícia. Onosso trabalho vai sendo conhecido pela comunidade em outros aspectos, o que faz com que a demanda também vá sendo orientada para outros objetos e o MP vá tendo visibilidade nessas demandas. Na hora que você faz e dá certo, o MP começa a aparecer. Outros canais de divulgação também são 
utilizados, como ofícios para Comissão de Direitos Humanos, para a Assembléia, para o Conselho Estadual, que começam a chamar para fazer parte das reuniões, das palestras, porque contatos com os Conselhos implicam inserção na agenda deles. As ONGs também nos procuram muito. Essa interação com outras instituições é necessária, porque o tipo de representação e de inquérito que a gente tem aqui normalmente não são de ofício, decorrem de representação de fora, até porque a gente não tem como identificar o que é mais importante, o que é prioritário naquela área. São essas instituições que são a nossa sensibilidade para os problemas que estão por aí. Se a gente provoca com um ofício, solicitando qualquer providência, a partir daí a gente é acionado para fazer uma série de outras coisas, participar em uma série de reuniões, enfim, o assédio e o volume de trabalho não acabam mais." (C)

Uma segunda atitude a ser repensada é o relativo desprezo que se tem por representações eventualmente formuladas de modo simplório, que de pronto deixam de ser levadas adiante por oferecerem suspeitas 'infundadas', deixando a dúvida sobre se uma investigação pelo órgão do MP não supriria a eventual falta de fundamentos e a provável descoberta de problemas mais amplos. Transcrevem-se abaixo alguns argumentos utilizados para não se instaurar inquérito civil, num caso tomado como exemplar pelo Caderno de Apoio preparado para que os novos Promotores da Cidadania conheçam o "posicionamento adotado nos casos mais frequientes": ${ }^{27}$

"Trata-se de pedido de providências no sentido de investigar o orçamento e as contas da Secretaria $X$, indicando a existência de irregularidades nas compras e distribuição de remédios, bem como nas transferências orçamentárias que deveriam estar sendo feitas pelo Estado aos Municípios.

(....) $\mathrm{O}$ representante informou que os fatos que poderiam subsidiar as investigações pleiteadas no pedido inicial estariam mencionados em outro procedimento, também de sua iniciativa, que se encontra em trâmite. Entretanto, o protocolado mencionado traz a narrativa de fatos ocorridos com o representante em relação ao medicamento Hormônio Calcitonia, utilizado pela avó do requerente e que teve sua distribuição suspensa pela Secretaria Estadual da Saúde.

Portanto, segundo o representante, apenas esses fatos, relacionados à sua avó, dariam ensejo à série de suspeitas que levanta, permitindo-lhe supor, entre outras coisas, a incorreta aplicação de recursos orçamentários do Estado e fraudes em procedimentos licitatórios da Secretaria da Saúde.

${ }^{27}$ Ministério Público do Estado de São Paulo. Escola Paulista do Ministério Público. Centro de Estudos e Aperfeiçoamento Funcional. Caderno de Apoio: Cidadania. 
Desta forma, o pedido de providências deve ser indeferido.

É importante ressaltar que a Promotoria de Justiça deve orientar sua atuação para a apuração de fatos especificamente indicados. A simples desconfiança, nascida de critérios estritamente pessoais, sem qualquer ligação com a realidade, não autoriza a atuação ministerial em socorro das pretensões do representante. 
Afinal, a iniciativa de determinada investigação é sempre gravosa para o Estado, que arca com as despesas de sua realização; para a Promotoria, que se desvia dos demais casos em trâmite e, no mais das vezes, à uma série de providências que lhe são requisitadas.

Assim, é curial que a iniciativa da instauração de procedimento investigatório não se dê a partir de suspeitas infundadas, mas que tenha por base fatos concretamente apontados a orientar a atividade do órgão ministerial.

Ora, embora indicando apenas suspeitas genéricas, pretende o representante que se proceda a uma investigação geral dos repasses orçamentários para os Municípios e em todos os processos licitatórios da Secretaria.

O Ministério Público não tem a função de controle abstrato das práticas administrativas. Esta função, mais adequadamente, cabe ao Tribunal de Contas e ao Poder Legislativo, a teor dos artigos 70 e 71 da Constituição Federal.

Ressalte-se que, na parte em que o representante indica a ocorrência dos fatos efetivamente ocorridos, já existe procedimento instaurado, não havendo qualquer razão que justifique a duplicidade do procedimento.

Ante o exposto, indefiro o pedido de instauração do inquérito civil, nos termos do art.15, inciso $2^{\circ}$, do Ato $\mathrm{n}^{\circ} 19 / 94$, determinando que se notifique o representante para, querendo, interpor recurso e o arquivamento dos autos, conforme promoção em separado."

A terceira e última atitude suscetível de crítica nos modos de captação de demandas se refere à ausência do MP em órgãos colegiados de participação popular, como canais organizados de reivindicações. ${ }^{28}$ Ainda que não se propugne pela representação do Ministério Público na composição dessas instâncias deliberativas, talvez fosse interessante que este se socorresse das pautas ali colocadas para orientar-se no desenvolvimento de estratégias mais abrangentes. Durante a pesquisa foi encontrado um Assento do Conselho Superior do MPE, que à época assim se posicionava:

"Assento CSMP no 06/94: Não serão feitas indicações de membros do Ministério Público para comporem comissões ou conselhos municipais, evitando-se impedimentos e incompatibilidades em prejuízo das funções típicas da instituição."

28 Sobre o caráter deliberativo das decisões emanadas por esses órgãos foram elaborados três estudos-base para oficina de trabalho promovida pelo Centro de Estudos e Pesquisas de Direito Sanitário (Cepedisa) em 1995: PASQUALOTTO, Adalberto. A Participação da Sociedade na Distribuição da Justiça; LOPES, José Reinaldo de Lima. Os Conselhos de Participação Popular - Validade Jurídica de suas Decisões; e DI PIETRO, Maria Sylvia Zanella. Participação da Comunidade em Órgãos da Administração Pública. 
Ao ser questionado a respeito, um dos membros do Conselho esclareceu:

"O assento é um consenso não necessariamente unânime do Conselho Superior, revisto anualmente. São entendimentos fixados pelo Conselho a cada ano de acordo com a opinião que esse órgão de administração superior tem sobre os diversos assuntos que the cabem. Na primeira reunião deste ano, por exemplo, os conselheiros novos receberam todos uma cópia dos assentos em vigor. Então há a oportunidade para eles reverem aqueles assentos, ou não. Agora, o assento não tem, evidentemente, vinculação, mas norteia de certa forma o caminho. Esse assento específico, no meu entender, tem que ser temperado, porque há conselhos em que o MP, mesmo não tendo interesse direto, deveria participar. Por outro lado, há a inconveniência da participação do MP porque muitas vezes pode-se entender que em determinados casos seria necessário processar o conselho ou membros do conselho por alguma deliberação que contrarie os interesses da coletividade. Se ele participa da deliberação, também está comprometido e não tem como agir com isenção." (O)

De qualquer modo, é bem provável que a consolidação do entendimento sobre quais sejam as 'funções típicas da instituição' seja mera questão de tempo.

Antes de concluir esta análise, permitimo-nos trazer a esta avaliação crítica dos depoimentos aqui transcritos uma última opinião capaz de resumir o que se buscou exprimir ao longo de todo o texto, nas palavras do próprio MP:

"O Ministério Público, de uns tempos para cá, tem inchado bastante, crescendo desordenadamente, o que dificulta a tomada de decisões. Acredito que uma instituição com menor quantidade de membros, mas muito melhor instrumentalizada, seria mais eficiente do que se fosse quantitativamente maior, mas sem infra-estrutura adequada para desempenhar suas inúmeras e sempre crescentes missões." (E) 


\section{CONCLUSÕES}

A complexidade inerente ao amplo e indeterminado direito à saúde não parece ser enfrentada em toda sua dimensão pelo Ministério Público, em gradativa adaptação às novas tarefas, na tentativa de superar hábitos próprios de uma instituição que até há pouco mais de uma década estava atrelada ao Poder Executivo e se destinava a funções bem mais restritas.

Em termos estruturais, o Ministério Público Federal se beneficia de maior flexibilidade do que o Estadual para ajustar seu organograma conforme a especialização temática se revele necessária.

A rigidez estrutural e a excessiva burocracia verificadas no encaminhamento de propostas de mudança no âmbito do Ministério Público do Estado representam obstáculo ao debate interno, indispensável à definição de macro-estratégias institucionais.

A especialização eventualmente construída pelo esforço pessoal ou proporcionada pela experiência em casos similares não parece ser valorizada como patrimônio institucional.

As decisões sobre prioridades de atuação são relegadas aos membros da carreira, cuja articulação, quando ocorre, se deve muito mais a afinidades pessoais do que a qualquer planejamento.

O tema da saúde é abordado por meio de procedimentos que privilegiam alguns aspectos em detrimento de outros, prejudicando a completude inerente à sua natureza e comprometendo um retorno totalmente eficaz à sociedade.

A interação do MP com as instituições que compõem o SUS e mesmo entre seus ramos Federal e Estadual mostra-se ainda demasiadamente pontual e distante, sem qualquer canal permanente para o fluxo de informações, verificando-se um retardo no reconhecimento mútuo das respectivas competências em cada caso concreto, que por vezes chega mesmo a potencializar os conflitos cuja solução estaria em poder do próprio Ministério Público.

Pelo que se pôde concluir, é possível afirmar que, durante esses primeiros anos sob a nova Constituição, o Ministério Público demonstrou estar avançando em direção a um desempenho mais eficaz no cumprimento de sua função de zelar pelo direito à saúde, embora ainda não se possa considerar tal função efetivamente cumprida, o que se atribui não tanto à complexidade que envolve o próprio direito material, que apenas começa a ser vislumbrada pela instituição, mas principalmente aos entraves internos que uma atuação atomizada pode gerar. 


\section{BIBLIOGRAFIA}

ALMEIDA, Maria Hermínia Tavares de. "Federalismo e Políticas Sociais". In: Revista Brasileira de Ciências Sociais. São Paulo: ANPOCS, nº 28, ano 10, jun.95, pp.88-108.

BANCO MUNDIAL/Banco Internacional para Reconstrução e Desenvolvimento. Resumo do Relatório sobre o Desenvolvimento Mundial - Investindo na Saúde. Washington, DC., 1993.

BOBBIO, Norberto. A era dos direitos. (trad. Carlos Nelson Coutinho) Rio de Janeiro: Campus, 1992.

BONAVIDES, Paulo. Curso de direito constitucional. 5.ed. São Paulo: Malheiros, 1994.

CAMPILONGO, Celso Fernandes. "Assistência jurídica e realidade social: apontamentos para uma tipologia dos serviços legais". In: PRESSBURGER, Miguel (org.) Discutindo a Assessoria Popular. Instituto de Apoio Jurídico Popular, Rio de Janeiro, 1991.

O trabalhador e o direito à saúde: a eficácia das normas jurídicas de proteção à saúde do trabalhador. Organização Panamericana de Saúde, Informes Técnicos, n.19, 1992.

. "Governo Representativo versus Governo dos Juízes: a 'autopoiese' dos sistemas político e jurídico." In: Universidade Federal do Pará. Cadernos da Pós-Graduação em Direito, n.7, 1996.

.Direito e democracia. São Paulo: Max Limonad, 1997.

CARVALHO, Guido Ivan de \& SANTOS, Lenir. Sistema Único de Saúde - Comentários à Lei Orgânica da Saúde (Lei 8.080/90 e Lei 8.142/90). São Paulo: Hucitec, 1992 (2.ed., 1995).

CEPEDISA. Centro de Estudos e Pesquisas de Direito Sanitário. O conceito constitucional de relevância pública. Série Direito e Saúde, 1. Brasília: Organização Panamericana de Saúde, 1992 (2.ed., 1994).

CHAVES, Mário de Magalhães. Saúde e sistemas. 3.ed. Rio de Janeiro: FGV, 1980.

CINTRA, Antônio Carlos de Araújo; GRINOVER, Ada Pellegrini \& DINAMARCO, Cândido Rangel. Teoria Geral do Processo. 3.ed. São Paulo: RT, 1983.

CORREIA, Sérvulo. "Introdução ao Direito da Saúde.”. In: Direito da Saúde e Bioética. Lisboa: Lex, 1991.

DALLARI, Dalmo de A. Elementos de teoria geral do Estado. 11.ed. São Paulo: Saraiva, 1985. 
DALLARI, Sueli G. A saúde do brasileiro. São Paulo: Moderna, 1987.

1988(a). . "O direito à saúde". In: Revista de Saúde Pública, São Paulo, 22(1):57-63, . "Uma nova disciplina: o direito sanitário". In: Revista de Saúde Pública, 22(4):327-34, 1988(b).

"O papel do município no desenvolvimento de políticas de saúde". In: Revista de Saúde Pública, São Paulo, 25(5):401-5, 1991.

- Os Estados brasileiros e o direito à saúde. São Paulo: Hucitec, 1995.

et al. "Advocacia em saúde no Brasil contemporâneo". In: Revista de Saúde Pública, São Paulo, 30(6):592-601, 1996.

DINAMARCO, Cândido Rangel. A instrumentalidade do processo. 2.ed. São Paulo: RT, 1990.

ECO, Umberto. Como se faz uma tese. (trad. Gilson Cesar Cardoso de Souza). São Paulo: Ed. Perspectiva, 1985.

FALCÃO, Joaquim de Arruda. "Democratização e Serviços Legais". In: FARIA, José Eduardo (org.) Direito e Justiça - a função social do Judiciário. São Paulo: Ática, 1989, pp.145-166.

FARIA, José Eduardo. Direito e economia na democratização brasileira. São Paulo: Malheiros, 1993.

Justiça e conflito (os juízes em face dos novos movimentos sociais). 2.ed. São Paulo: RT, 1992.

FERRAZ, Antônio Augusto Mello de Camargo (coord.). Ministério Público: instituição e processo. São Paulo: Atlas, 1997.

FERRAZ JR., Tércio Sampaio. Introdução ao estudo do direito - técnica, decisão, dominação. São Paulo: Atlas, 1988.

GOODE, W.J. \& HATT, P.K. Métodos em Pesquisa Social. 2.ed. São Paulo: Nacional, 1968.

GRECO FILHO, Vicente. Direito Processual Civil Brasileiro. Vol. 1. 5.ed. São Paulo: Saraiva, 1988.

GRINOVER, Ada Pellegrini (coord.). A tutela dos interesses difusos: doutrina, jurisprudência e trabalhos forenses. Série Estudos Jurídicos, n.1. São Paulo: Max Limonad, 1984.

HARVARD LAW SCHOOL. Economic and social rights and the right to health. 
Human Rights Program, 1995.

IDESP - Instituto de Estudos Econômicos Sociais e Políticos. O Ministério Público e a Justiça no Brasil - Relatório de pesquisa. São Paulo: IDESP, 1996.

KELSEN, Hans. Teoria pura do direito. (trad. João Baptista Machado). São Paulo: Livraria Martins Fontes Editora, 1985.

LAMOUNIER, Bolívar. "Redemocratização e Estudo das Instituições Políticas no Brasil”. In: MICELI, Sérgio (org.), Temas e Problemas da Pesquisa em Ciências Sociais. Série Seminários e Debates. São Paulo: Idesp/Sumaré; Rio de Janeiro: Fund.Ford, 1992, pp. 43-53.

LOPES, José Reinaldo de Lima. (a) "Direito subjetivo e direitos sociais: o dilema do Judiciário no Estado Social de Direito". In: FARIA, José Eduardo (org.) Direitos humanos, direitos sociais e justiça. São Paulo: Malheiros, 1994, pp.113-143.

(b) "Judiciário, Democracia, Políticas Públicas." In: VVAA. Direito e Comércio Internacional: tendências e perspectivas: estudos em homenagem ao Professor Irineu Strenger. São Paulo, LTr, 1994.

MACEDO JR., Ronaldo Porto. "A evolução institucional do Ministério Público brasileiro". In: SADEK, Maria Tereza (org.) Uma introdução ao estudo da justiça. Série Justiça. São Paulo: Idesp/Sumaré, 1995, pp.39-52.

"O Quarto Poder e o Terceiro Setor. O Ministério Público e as Organizações Não-Governamentais sem fins lucrativos - Estratégias para o futuro". In: VIGLIAR, Marcelo Menezes \& MACEDO JR., Ronaldo Porto. Ministério Público II. São Paulo: Atlas, 1999 (no prelo).

MANCUSO, Rodolfo de Camargo. Interesses difusos - conceito e legitimação para agir. 2.ed. São Paulo: RT, 1991.

MAZZILLI, Hugo Nigri. O Ministério Público na Constituição de 1988. São Paulo: Saraiva, 1989. - Manual do Promotor de Justiça. 2.ed. São Paulo: Saraiva, 1991. Regime Jurídico do Ministério Público. São Paulo: Saraiva, 1993. - "Visão crítica da formação profissional e das funções do promotor de justiça” in NALINI, José Renato (coord.). Formação Jurídica. São Paulo: RT, 1994, pp.58-113.

MENDES, Eugênio Vilaça. Uma agenda para a saúde. São Paulo: Hucitec, 1996.

MILARÉ, Édis (org.) Ação civil pública - Lei 7.347/85 - Reminiscências e reflexões após dez anos de aplicação. São Paulo: RT, 1995.

OPAS. Organização Panamericana de Saúde. Relações público/privado na eficácia do direito à saúde. Informes Técnicos, n.62. Washington, DC: OPAS, 1998. 
POGGI, Gianfranco. A evolução do Estado moderno - uma introdução sociológica.. (trad. Álvaro Cabral). Rio de Janeiro: Zahar, 1981.

ROCHA, Julio Cesar de Sá da. Direito da saúde: direito sanitário na perspectiva dos interesses difusos e coletivos. São Paulo: LTr, 1999.

ROSEN, George. Uma história da saúde pública. (trad. Marcos F. S. Moreira, colab. José Ruben Alcântara Bonfim). 2.ed. São Paulo: Hucitec : Ed.Unesp; Rio de Janeiro: Abrasco, 1994.

SADEK, Maria Tereza (org.) O Judiciário em Debate. Série Justiça. São Paulo: Idesp/Sumaré, 1995.

SALLES, Carlos Alberto de. A legitimação do Ministério Público para a defesa de direitos e garantias constitucionais. Dissertação de mestrado apresentada à Faculdade de Direito da Universidade de São Paulo, 1992.

SANTOS, Boaventura de Sousa. "Introdução à sociologia da administração da justiça". In: FARIA, José Eduardo (org.) Direito e Justiça - a função social do Judiciário. São Paulo: Ática, 1989, pp.39-65.

SANTOS, Wanderley Guilherme dos. Razões da desordem. Rio de Janeiro: Rocco, 1993.

SILVA, José Afonso da. Curso de Direito Constitucional Positivo. 9.ed. São Paulo: Malheiros, 1992.

VITA, Álvaro de. Justiça Liberal: Argumentos liberais contra o neoliberalismo. Rio: Paz e Terra, 1993.

WARAT, Luiz Alberto. "O senso comum teórico dos juristas". In: O direito achado na rua. Curso de Extensão Universitária à Distância. Brasília: Editora UnB, 1987, pp.105-108.

YIN, Robert K. Case Study Research - Design and Methods. Beverly Hills: Sage, 1984. 


\section{ANEXO 1-A}

Demandas registradas no Ministério Público Federal

\begin{tabular}{|c|c|c|c|}
\hline $\mathbf{N}^{\mathbf{o}}$ & MATÉRIA & REGISTRO* & ART. \\
\hline 1 & $\begin{array}{l}\text { Pedido de esclarecimento sobre acidente decorrente de } \\
\text { atendimento médico no Hospital dos Servidores Públicos do } \\
\text { Estado de São Paulo. }\end{array}$ & $\begin{array}{c}\text { CODID } \\
15 / 89\end{array}$ & 200 \\
\hline 2 & $\begin{array}{l}\text { Visa esclarecimento sobre significado das palavras "bebida } \\
\text { dietética / fenilcetonúricos / contém fenilalanina" contidas em } \\
\text { embalagens de "Diet Coke".` }\end{array}$ & $\begin{array}{l}\text { CODID } \\
16 / 89\end{array}$ & 200 \\
\hline 3 & Falta do “teste do pezinho" (Lei Estadual 3914/83). ` & $\begin{array}{c}\text { CODID } \\
51 / 89\end{array}$ & 200 \\
\hline 4 & Higienização de embalagens plásticas retornáveis da Coca-Cola. & $\begin{array}{l}\text { CODID } \\
26 / 90\end{array}$ & 200 \\
\hline 5 & Medicamento essencial retirado do mercado. & $\begin{array}{l}\text { CODID } \\
28 / 90\end{array}$ & 200 \\
\hline 6 & $\begin{array}{l}\text { Beneficência Portuguesa. Cobrança de complementação de } \\
\text { pagamento. }\end{array}$ & $\begin{array}{l}\text { Portaria s/n } \\
\text { de } 20.11 .91\end{array}$ & 198 \\
\hline 7 & SUDS. Aplicação de recursos $1987-90$ & $\begin{array}{l}\text { CODID } \\
28 / 91\end{array}$ & 198 \\
\hline 8 & $\begin{array}{l}\text { MS - Programa de Suplementação Alimentar. Alimentos } \\
\text { deteriorados. }\end{array}$ & $\begin{array}{l}\text { CODID } \\
31 / 91\end{array}$ & 200 \\
\hline 9 & $\begin{array}{l}\text { Roubo de material radiativo vendido a empresa privada sem } \\
\text { autorização da CNEN. }\end{array}$ & $\begin{array}{l}\text { CODID } \\
35 / 91\end{array}$ & 200 \\
\hline 10 & Intoxicação. Tratamento pelo INAMPS não concedido. & $\begin{array}{l}\text { CODID } \\
49 / 92\end{array}$ & 196 \\
\hline 11 & $\begin{array}{l}\text { Adequação de normas do regulamento de certificação de } \\
\text { preservativos masculinos pelo INMETRO. }\end{array}$ & ICP 03/92 & 200 \\
\hline 12 & Hemofílicos. Contaminação do vírus da AIDS. & ICP 04/92 & 200 \\
\hline 13 & Representação contra representantes filiados do Conselho & CODID & 197 \\
\hline
\end{tabular}

// = Procedimentos-satélite

$\mathrm{E}=$ Livro de Registro de Expedientes

$\mathrm{R}=$ Livro de Registro de Representações

ICP = Livro de Registro de Inquéritos Civis Públicos

CODID = Livro de Registros da Coordenadoria de Direitos e Interesses Difusos e Coletivos (atual SOTC) 


\begin{tabular}{|c|c|c|c|}
\hline $\mathbf{N}^{\mathbf{o}}$ & MATÉRIA & REGISTRO* & ART. \\
\hline & Nacional de Técnicos de Radiologia & $05 / 94$ & \\
\hline 14 & $\begin{array}{l}\text { Eventual interesse de membros do MPF em representar a } \\
\text { instituição junto ao Conselho Nacional da Reserva da Biosfera } \\
\text { da Mata Atlântica. }\end{array}$ & E 01/94 & 198 \\
\hline 15 & $\begin{array}{l}\text { MS-SNVS: Portaria } 9 / 94 \text { revoga dispositivo de Portaria } 88 \text {, que } \\
\text { exigia na fabricação/importação de preservativos a apresentação } \\
\text { do certificado do INMETRO. }\end{array}$ & R 46/94 & 200 \\
\hline 16 & $\begin{array}{l}\text { Prefeitura Municipal de São Paulo. Retenção injustificada de } \\
\text { recursos federais destinados ao FUMDES. }\end{array}$ & R 156/94 & 198 \\
\hline 17 & Troca de criança recém-nascida em hospital do INAMPS. & R $158 / 94$ & 197 \\
\hline 18 & $\begin{array}{l}\text { Cópia de IC da PFDC que relata quadro caótico na saúde. Estado } \\
\text { de calamidade pública no } S \boldsymbol{U} \text { S. }\end{array}$ & R $182 / 94$ & 198 \\
\hline 19 & $\begin{array}{l}\text { Legalidade de ato de divulgação do Conselho Federal de } \\
\text { Terapias, instituição ainda não criada. }\end{array}$ & R 186/94 & 197 \\
\hline 20 & $\begin{array}{l}\text { Empresa alimentícia. Venda de matéria prima sem registro no } \\
\text { MS e sem autorização para expor produtos à venda ou ao } \\
\text { consumo. Propaganda enganosa. }\end{array}$ & R 192/94 & 200 \\
\hline 21 & $\begin{array}{l}\text { Medicamento. Acidente de consumo. Omissão de esclarecimento } \\
\text { na bula. }\end{array}$ & $\begin{array}{l}R 209 / 94 \\
\quad / / \\
\text { ICP 02/96 }\end{array}$ & 200 \\
\hline 22 & $\begin{array}{l}\text { SUS. CPI para apurar irregularidades do INAMPS (em extinção). } \\
\text { Auditoria nas SES referente a recursos do SUS em S.Paulo } \\
\text { encerrada em face da não-apresentação dos documentos } \\
\text { contábeis e processos de pagamentos. Não-apuração das } \\
\text { aplicaçôes efetivas dos recursos provenientes do MS, por força } \\
\text { do convênio } S U S \text { S } 01 / 91 \text {, nas ações de saúde. }\end{array}$ & $\begin{array}{l}R 224 / 94 \\
\quad / / \\
\text { ICP } 01 / 95\end{array}$ & 198 \\
\hline 23 & $\begin{array}{l}\text { Apuração de desvio de finalidade na aplicação de recursos } \\
\text { federais pela Prefeitura Municipal de S.Paulo. Avaliação e } \\
\text { monitoramento da execução de ações de saúde no Município, bem } \\
\text { como atuação do Conselho Municipal de Saúde e outras } \\
\text { instituições }\end{array}$ & $\begin{array}{l}\text { ICP 04/94 } \\
\quad / / \\
\text { E } 31 / 96\end{array}$ & 198 \\
\hline 24 & $\begin{array}{l}\text { Patrimônio público. Saúde. Irregularidade administrativa. } \\
\text { Hospital Emílio Ribas. }\end{array}$ & E $17 / 95$ & 198 \\
\hline
\end{tabular}




\begin{tabular}{|c|c|c|c|}
\hline $\mathbf{N}^{\mathbf{0}}$ & MATÉRIA & REGISTRO* & ART. \\
\hline 25 & $\begin{array}{l}\text { Atraso, por órgãos competentes do governo federal, no repasse } \\
\text { dos recursos aos prestadores de serviços contratados e } \\
\text { conveniados ao SUS. }\end{array}$ & R 01/95 & 198 \\
\hline 26 & $\begin{array}{l}\text { Investigação em bancos de sangue. Notícia veiculada pela Folha } \\
\text { de S.Paulo acerca do vírus HTLV1, causador de paralisia } \\
\text { gradativa em todo o corpo. }\end{array}$ & R 14/95 & 200 \\
\hline 27 & $\begin{array}{l}\text { Apuração de providências para retirada de produtos inflamáveis } \\
\text { pertencentes ao INSS. }\end{array}$ & R 16/95 & 200 \\
\hline 28 & $\begin{array}{l}\text { Res.139, determinando à SNVS publicação de portaria } \\
\text { normatizando a exportação de talidomida. }\end{array}$ & R $17 / 95$ & 200 \\
\hline 29 & $\begin{array}{l}\text { A) cadastramento irregular de prestação de serviços para o SUS; } \\
\text { B) inexistência de critérios técnicos na distribuição de AIHs; C) } \\
\text { existência, em S.Paulo, de vários profissionais médicos } \\
\text { autônomos, cadastrados pela SES e remunerados diretamente } \\
\text { pela União, mediante crédito em conta do profissional (Cód.7), } \\
\text { com faturamento acima de US\$10 mil (maio/94) - fls. } 88 \text { e } 103 \text { a } \\
105 \text { do Relatório da CPI. }\end{array}$ & $\begin{array}{l}\mathrm{R} 21 / 95 \\
\text { (expediente } \\
\text { 2) }\end{array}$ & 198 \\
\hline 30 & $\begin{array}{l}\text { Irregularidades em unidades de saúde privadas no âmbito do } \\
\text { Estado de S.Paulo, estando elencadas às fls. } 158 / 160 \text { do Relatório } \\
\text { da CPI aqueles que já foram objeto de auditoria. }\end{array}$ & $\begin{array}{c}R 22 / 95 \\
\text { (expediente } \\
\text { 3) } \\
/ / \\
\text { ICP } 09 / 95 \\
\text { a ICP 27/95 } \\
/ / \\
\text { ICP } 32 / 95\end{array}$ & 198 \\
\hline 31 & Irregularidades no processo de extinção do INAMPS. & $\begin{array}{l}\mathrm{R} 23 / 95 \\
\text { (expediente } \\
\text { 4) }\end{array}$ & 198 \\
\hline 32 & $\begin{array}{l}\text { Poluição ambiental decorrente de incineração de lixo } \\
\text { hospitalar. }{ }^{`}\end{array}$ & R 56/95 & 200 \\
\hline 33 & $\begin{array}{l}\text { Irregularidades cometidas contra idosos internos na "Instituição } \\
\text { Assistencial Nosso Lar". }\end{array}$ & R 75/95 & 200 \\
\hline 34 & $\begin{array}{l}\text { Portador de deficiência física e mental solicita auxílio para obter } \\
\text { tratamento adequado. }\end{array}$ & R 76/95 & 196 \\
\hline 35 & $\begin{array}{l}\text { Meio ambiente e saúde pública. Proprietário arrenda terreno para } \\
\text { terceiros para instalação de pocilgas. }\end{array}$ & R 77/95 & 200 \\
\hline 36 & $\begin{array}{l}\text { Conflito de legislação municipal com legislação federal } \\
\text { referentes a jornada de trabalho dos fisioterapeutas e terapeutas }\end{array}$ & R 97/95 & 197 \\
\hline
\end{tabular}




\begin{tabular}{|c|c|c|c|}
\hline $\mathbf{N}^{\mathbf{o}}$ & MATÉRIA & REGISTRO* & ART. \\
\hline & ocupacionais servidores do Município de S.Paulo. & & \\
\hline 37 & $\begin{array}{l}\text { Denúncia de procedimento do INSS com relação a repasse de } \\
\text { verbas aos hospitais e Santas Casas conveniados. }\end{array}$ & R $127 / 95$ & 198 \\
\hline 38 & $\begin{array}{l}\text { Troca de criança. Maternidade Paulistânia, conveniada ao INSS. } \\
\text { Falta de documentação pelo citado nosocômio por furto da } \\
\text { mesma, necessário para análise do caso (sic). Suscitado conflito } \\
\text { de competência entre Justiça Federal e Justiça Estadual. }\end{array}$ & R $131 / 95$ & 197 \\
\hline 39 & $\begin{array}{l}\text { Patrimônio público e saúde. Notícia de que MS procedeu a } \\
\text { empréstimos aos hospitais prestadores de serviços ao } \\
\text { INAMPS/SUS, sob a rubrica "Adiantamento de AIH" ou } \\
\text { "Adiantamento por serviços já efetuados", empréstimos em } \\
\text { princípio sem base legal, ferindo princípios do SUS. }\end{array}$ & R $153 / 95$ & 198 \\
\hline 40 & $\begin{array}{l}\text { Verificação, no Estado de S.Paulo, de cobrança de produto } \\
\text { Bioclusine como se fosse produto substitutivo de pele, cujo valor } \\
\text { de faturamento é maior, e não como simples curativo (valor } \\
\text { menor) }\end{array}$ & R $154 / 95$ & 200 \\
\hline 41 & $\begin{array}{l}\text { Direito constitucional. Consumidor. Comercialização irregular } \\
\text { de medicamento. Ausência de registro no MS. Produto importado } \\
\text { Chroma Gum } 100 .\end{array}$ & R $168 / 95$ & 200 \\
\hline 42 & $\begin{array}{l}\text { Cadastramento irregular de prestadores de serviços para o SUS. } \\
\text { Inexistência de critérios técnicos na distribuição de } \boldsymbol{A I H s} \text {. }\end{array}$ & R $173 / 95$ & 198 \\
\hline 43 & $\begin{array}{l}\text { Saúde. Precariedade no atendimento médico à população. } \\
\text { Instituto de Infectologia Emílio Ribas. }\end{array}$ & R $174 / 95$ & 200 \\
\hline 44 & $\begin{array}{l}\text { Patrimônio público. Saúde. Faturamento de AIHs. Regularidade. } \\
\text { Hospital Maternidade São José. } \checkmark\end{array}$ & $R \mathbf{R} 175 / 95$ & 198 \\
\hline 45 & Idem. Hospital do Ipiranga. $\checkmark$ & $R$ 177/95 & 198 \\
\hline 46 & Idem. Hospital Psiquiátrico da Vila Mariana. $\checkmark$ & $R$ 178/95 & 198 \\
\hline 47 & Idem. Centro Médico da Lapa (CEMEL). $`$ & $R$ 180/95 & 198 \\
\hline 48 & Idem. CEMA - Hospital Especializado Ltda. $\checkmark$ & $R \quad 181 / 95$ & 198 \\
\hline 49 & Idem. Casa de Saúde e Maternidade Santa Ângela. ` & $R$ 182/95 & 198 \\
\hline 50 & Idem. Instituto Montreal. $`$ & $R \quad 183 / 95$ & 198 \\
\hline 51 & Idem. Hospital Maternidade Santo Antonio. $`$ & $R$ 184/95 & 198 \\
\hline 52 & Idem. Organização Médica Cruzeiro do Sul. ${ }^{\checkmark}$ & $R \quad 186 / 95$ & 198 \\
\hline
\end{tabular}




\begin{tabular}{|c|c|c|c|}
\hline $\mathbf{N}^{\mathbf{o}}$ & MATÉRIA & REGISTRO* & ART. \\
\hline 53 & Idem. Maternidade Dr. Cury. $`$ & R $187 / 95$ & 198 \\
\hline 54 & Idem. Santa Casa de Misericórdia. $`$ & $R$ 188/95 & 198 \\
\hline 55 & Idem. Hospital das Damas. ${ }^{\checkmark}$ & $R \quad 189 / 95$ & 198 \\
\hline 56 & Idem. Hospital Maternidade João Paulo II. ` & R 190/95 & 198 \\
\hline 57 & $\begin{array}{l}\text { Direito constitucional. Direitos humanos. Saúde pública. Falta de } \\
\text { atendimento e fechamento de hospital no âmbito estadual e } \\
\text { municipal da área de abrangência do ERSA-5. Evasão de } \\
\text { profissionais da saúde por baixos salários. } \\
\text { Itaim Paulista. São Paulo-SP. }\end{array}$ & R 195/95 & 198 \\
\hline 58 & $\begin{array}{l}\text { Patrimônio público. Saúde. Faturamento de AIHs. Regularidade. } \\
\text { Santa Casa de Santa Marcelina. } \checkmark\end{array}$ & $R 200 / 95$ & 198 \\
\hline 59 & Idem. Hospital Monumento. $`$ & $R 202 / 95$ & 198 \\
\hline 60 & Idem. Hospital Stella Maris. $`$ & $R 206 / 95$ & 198 \\
\hline 61 & Idem. Hospital Bandeirantes. $`$ & $R 207 / 95$ & 198 \\
\hline 62 & $\begin{array}{l}\text { Patrimônio público. Saúde. Denúncias formuladas pelo Conselho } \\
\text { Estadual dos Direitos da Pessoa Humana sobre irregularidades } \\
\text { no Hospital Emílio Ribas. }\end{array}$ & R 209/95 & 198 \\
\hline 63 & $\begin{array}{l}\text { Fraude contra consumidor. Cobrança de valor superior ao custo } \\
\text { em materiais implantados e outros utilizados em cirurgia. Hospital } \\
\text { Santa Lucinda }(\boldsymbol{S U S}) .\end{array}$ & R 248/95 & 198 \\
\hline 64 & $\begin{array}{l}\text { Patrimônio público. Saúde. Apuração referente a cadastro } \\
\text { irregular de prestadora de serviços ao } \boldsymbol{S U S} \text {. } \\
\text { Maccki Engenharia Biomédica Ltda. }\end{array}$ & R 267/95 & 198 \\
\hline 65 & $\begin{array}{l}\text { Representação } 224 / 94 \text {. } \\
\text { Patrimônio público e social. SUS. Irregularidade na gestão de } \\
\text { recursos. }\end{array}$ & $\begin{array}{l}\text { ICP 01/95 } \\
\quad / / \\
R 224 / 94\end{array}$ & 198 \\
\hline 66 & $\begin{array}{l}\text { Representação } 197 / 94 \text { (categorizada no Art. } 37 \text { ) } \\
\text { Irregularidade na aplicação de recursos federais transferidos para } \\
\text { OSEC. Indícios de possível prática de ato de improbidade } \\
\text { administrativa. }\end{array}$ & $\begin{array}{l}\text { ICP 02/95 } \\
\quad / / \\
R \text { 197/94 }\end{array}$ & 198 \\
\hline 67 & $\begin{array}{l}\text { Direito constitucional. Patrimônio público. Saúde. Convênios. } \\
\text { Fator de estímulo à municipalização . Fator de apoio à } \\
\text { municipalização. Convênio. Repasse. Legalidade. Irregularidade. } \\
\text { Municípios do Estado SP. }\end{array}$ & ICP 03/95 & 198 \\
\hline
\end{tabular}




\begin{tabular}{|c|c|c|c|}
\hline $\mathbf{N}^{\mathbf{o}}$ & MATÉRIA & REGISTRO* & ART. \\
\hline $\begin{array}{c}68 \\
\mathbf{a} \\
70\end{array}$ & $\begin{array}{l}\text { CESAI. Irregularidades. Ausência de médico responsável. Surto } \\
\text { de varicela hemorrágica. Óbito de indígena. Omissão de } \\
\text { providências adequadas. Serviços e instalações médicas } \\
\text { deficitários. Falta de higiene. Assistência médica deficitária. } \\
\text { Desídia funcional. }\end{array}$ & $\begin{array}{l}\text { ICP } 06 / 95 \\
\quad \mathrm{a} \\
\text { ICP } 08 / 95 \\
\text { (total: } 03 \text { ) }\end{array}$ & 200 \\
\hline $\begin{array}{c}71 \\
\mathbf{a} \\
89\end{array}$ & $\begin{array}{l}\text { Todos com origem na Representação 22/95. } \\
\text { Patrimônio público. Saúde. Faturamento de AIHs. Regularidade. } \\
\text { Sistema de órteses e próteses. } \\
\text { (várias instituições) }\end{array}$ & $\begin{array}{l}\text { ICP } 09 / 95 \\
\quad \mathrm{a} \\
\text { ICP } 27 / 95 \\
\text { (total: } 19 \text { ) }\end{array}$ & 198 \\
\hline $\begin{array}{c}90 \\
\mathbf{a} \\
92\end{array}$ & $\begin{array}{l}\text { Saúde pública. Consumidor. Representação escrita, noticiando } \\
\text { infração do disposto no art.18 da Lei } 5991 / 73 \text { e arts.57, } 35 \text { e } 27 \text { do } \\
\text { Dec. 793/93 por empresas farmacêuticas. Não-manutenção de } \\
\text { técnicos farmacêuticos. Realização de fracionamento indevido de } \\
\text { medicamentos. Oferecimento de serviço de aplicação de } \\
\text { injetáveis sem supervisão de técnico habilitado. Entrega de } \\
\text { prescrição de medicamentos a balconistas não habilitados. } \\
\text { Aviamento de receitas de medicamentos magistrais a terceiros, } \\
\text { entre outros fatos. }\end{array}$ & $\begin{array}{l}\text { ICP } 29 / 95 \\
\quad \mathrm{a} \\
\text { ICP } 31 / 95 \\
\text { (total: } 03 \text { ) }\end{array}$ & 197 \\
\hline 93 & $\begin{array}{l}\text { Apenso III da Representação 22/95. } \\
\text { Saúde. Apuração da regularidade do funcionamento do Sistema } \\
\text { de Informações Ambulatoriais do SUS. }\end{array}$ & $\begin{array}{c}\text { ICP } 32 / 95 \\
/ / \\
R 22 / 95 \\
/ / \\
\text { ICP 09/95 } \\
a \\
\text { ICP 27/95 }\end{array}$ & 198 \\
\hline 94 & $\begin{array}{l}\text { Direito constitucional. Tratamento incorreto. Ocorrência de erro } \\
\text { médico grave no Hosp. V. Nova Cachoeirinha/SP. }\end{array}$ & E 18/96 & 197 \\
\hline 95 & $\begin{array}{l}\text { Consumidor e ordem econômica. Publicidade comercial. Venda } \\
\text { do medicamento “Prozac" via "on line", pelo Laboratório Eli } \\
\text { Lilly do Brasil Ltda. } `\end{array}$ & E 23/96 & 200 \\
\hline 96 & $\begin{array}{l}\text { Direito constitucional. Direito à vida e à saúde . Irregularidade } \\
\text { no tratamento dos portadores de AIDS pela rede municipal de } \\
\text { saúde. } \checkmark\end{array}$ & $\begin{array}{c}E 26 / 96 \\
/ / \\
\text { ICP } 12 / 96\end{array}$ & 200 \\
\hline 97 & Possíveis irregularidades na aplicação do PAS. ${ }^{\vee}$ & E 30/96 & 198 \\
\hline 98 & $\begin{array}{l}\text { Aplicação irregular do Fundo Municipal de Saúde de São } \\
\text { Paulo/SP no BANRISUL. }\end{array}$ & $\begin{array}{c}\text { E 31/96 } \\
/ / \\
\text { ICP 04/94 }\end{array}$ & 198 \\
\hline 99 & $\begin{array}{l}\text { Patrimônio público. Saúde. Programa de Inspeção em Unidades } \\
\text { Hemoterápicas - PNIUH. Credenciamento de "auditores }\end{array}$ & R 07/96 & 200 \\
\hline
\end{tabular}




\begin{tabular}{|c|c|c|c|}
\hline $\mathbf{N}^{\mathbf{o}}$ & MATÉRIA & REGISTRO* & ART. \\
\hline & federais". Port. 127, de 08.12.95, da SNVS/MS. ${ }^{\checkmark}$ & & \\
\hline $\begin{array}{c}100 \\
\mathbf{a} \\
116\end{array}$ & $\begin{array}{l}\text { Patrimônio público. Saúde. Apuração referente ao cadastramento } \\
\text { irregular de prestadora de serviços ao SUS. }\end{array}$ & $\begin{array}{l}\mathrm{R} 08 / 96 \\
\mathrm{a} \\
\mathrm{R} 23 / 96 \\
\text { (total: } 16 \text { ) }\end{array}$ & 198 \\
\hline 117 & $\begin{array}{l}\text { Patrimônio público. Saúde. Boicote ao Plano de Atendimento à } \\
\text { Saúde (PAS). Lei Municipal no } 11.866 / 95 .\end{array}$ & R 25/96 & 198 \\
\hline $\begin{array}{c}118 \\
a \\
167\end{array}$ & $\begin{array}{l}\text { Saúde. Apuração de regularidade no funcionamento do Sistema } \\
\text { de Informação Ambulatorial - SIA/SUS. } \checkmark\end{array}$ & $\begin{array}{l}\text { R 29/96 } \\
\quad \text { a } \\
\text { R 78/96 } \\
\text { (total: } 50 \text { ) }\end{array}$ & 198 \\
\hline 168 & $\begin{array}{l}\text { Direito constitucional. Direito à vida e à saúde. Apuração das } \\
\text { responsabilidades pelas chacinas ocorridas na Grande São Paulo. } \\
\text { Atuação conjunta MPF/MPE. }\end{array}$ & R 83/96 & 196 \\
\hline 169 & $\begin{array}{l}\text { Consumidor. Medicamento causador de efeitos colaterais } \\
\text { gravíssimos. Talidomida. }\end{array}$ & R $104 / 96$ & 200 \\
\hline 170 & $\begin{array}{l}\text { Solicitação para que seja indenizada segunda geração de vítimas } \\
\text { da talidomida. }\end{array}$ & $\begin{array}{l}R 157 / 96 \\
\quad / / \\
\text { ICP } 14 / 96\end{array}$ & 200 \\
\hline 171 & $\begin{array}{l}\text { Patrimônio público e social. Solicitação para que seja investigada } \\
\text { a legalidade da criação e funcionamento do Conselho Federal de } \\
\text { Terapia. }\end{array}$ & R 158/96 & 197 \\
\hline 172 & $\begin{array}{l}\text { Publicidade enganosa. Jornal "Naturavit Notícias". Vantagens do } \\
\text { produto "Melatonina Spray". } \checkmark\end{array}$ & $\begin{array}{l}R \text { 170/96 } \\
\quad / / \\
\text { ICP } 05 / 97\end{array}$ & 200 \\
\hline 173 & $\begin{array}{l}\text { Patrimônio público e social. SUS. Pgto. adm. AIHs rejeitadas na } \\
\text { competência setembro/95. Fundação Zerbini e Fundação Adib } \\
\text { Jatene - Instituto Dante Pazzanese. }\end{array}$ & R $174 / 96$ & 198 \\
\hline 174 & $\begin{array}{l}\text { Patrimônio público e social. Saúde. Consumidor. Cobrança de } \\
\text { cirurgias realizadas através do SUS pelos médicos da Sociedade } \\
\text { Portuguesa de Beneficência. }\end{array}$ & R 195/96 & 198 \\
\hline 175 & $\begin{array}{l}\text { Consumidor. Denúncia quanto a acidente de consumo com } \\
\text { medicamento "Colírio Fluo-fenicol". }\end{array}$ & $\begin{array}{c}\text { ICP 02/96 } \\
/ / \\
R \text { 209/94 }\end{array}$ & 200 \\
\hline 176 & $\begin{array}{l}\text { Direito constitucional. Direito à vida e à saúde. Irregularidades } \\
\text { no PAS. }\end{array}$ & $\begin{array}{l}\text { ICP 12/96 } \\
\text { // } \\
\text { E 26/96 }\end{array}$ & 200 \\
\hline
\end{tabular}




\begin{tabular}{c|l|c|c}
$\mathbf{N}^{\mathbf{0}}$ & MATÉRIA & REGISTRO" & ART. \\
\hline $\mathbf{1 7 7}$ & $\begin{array}{l}\text { Outros interesses difusos e coletivos. Solicitação para que seja } \\
\text { indenizada a segunda geração de vítimas da talidomida. }\end{array}$ & $\begin{array}{c}\text { ICP 14/96 } \\
/ / \\
\mathbf{R}\end{array}$ & 200 \\
\hline $\mathbf{1 7 8}$ & $\begin{array}{l}\text { Consumidor e ordem econômica. Publicidade enganosa no jornal } \\
\text { "Naturavit Notícias", que alardeia vantagens do produto } \\
\text { "Melatonina Spray". }\end{array}$ & $\begin{array}{c}\text { ICP 05/97 } \\
/ /\end{array}$ & 200 \\
\hline
\end{tabular}


$\underline{\text { MPF - Demandas excluídas do universo de estudo em razão da matéria }}$

\begin{tabular}{|c|c|c|c|}
\hline $\mathbf{N}^{\mathbf{o}}$ & MATÉRIA & REGISTRO & ART. \\
\hline 1 & Planos de saúde. Assistência médica a aidéticos. & $\begin{array}{l}\text { CODID } \\
27 / 90\end{array}$ & 199 \\
\hline 2 & Seguro-saúde. Não-cumprimento de cláusula. (Golden Cross) & $\begin{array}{l}\text { CODID } \\
08 / 91\end{array}$ & 199 \\
\hline 3 & $\begin{array}{l}\text { CF, art.201, } \S 5^{\circ} \text { ("Nenhum benefício que substitua o salário de } \\
\text { contribuição ou rendimento do trabalho do segurado terá valor } \\
\text { mensal inferior ao salário mínimo.") }\end{array}$ & $\begin{array}{l}\text { CODID } \\
15 / 91\end{array}$ & 194 \\
\hline 4 & $\begin{array}{l}\text { Fixação de valores pela } \mathrm{AMB} \text { para cobrança de convênios } \\
\text { médicos. }\end{array}$ & $\begin{array}{l}\text { CODID } \\
11 / 92\end{array}$ & 199 \\
\hline 5 & $\begin{array}{l}\text { Hospital de Heliópolis. Superfaturamento em concorrência } \\
\text { pública. }\end{array}$ & $\begin{array}{l}\text { CODID } \\
47 / 92\end{array}$ & 37 \\
\hline 6 & $\begin{array}{l}\text { INAMPS e SUS. Fraudes. Pagamentos feitos a hospitais, } \\
\text { clínicas, laboratórios e médicos credenciados. }\end{array}$ & $\begin{array}{l}\text { CODID } \\
40 / 93\end{array}$ & 37 \\
\hline 7 & Conselho Nacional de Seguridade Social & $\begin{array}{c}\text { CODID } \\
68 / 93\end{array}$ & 194 \\
\hline 8 & $\begin{array}{l}\text { Apuração de eventual lesão ao direito constitucional à saúde e } \\
\text { aos direitos do consumidor de serviços de assistência médica, } \\
\text { especialmente no tocante às cláusulas restritivas de cobertura às } \\
\text { doenças crônicas e moléstias infecto-contagiosas. }\end{array}$ & ICP $02 / 93$ & 199 \\
\hline 9 & ERSAS. Irregularidades em licitações & R 43/94 & 37 \\
\hline 10 & $\begin{array}{l}\text { Patrimônio público. Irregularidade na aplicação de recursos } \\
\text { públicos federais transferidos para OSEC. Lei } 8429 / 92 \text {. }\end{array}$ & $\begin{array}{l}R \text { 197/94 } \\
\quad / / \\
\text { ICP } 02 / 95\end{array}$ & 37 \\
\hline 11 & $\begin{array}{l}\text { Apuração de prática de publicidade omissiva e/ou enganosa, bem } \\
\text { como dos danos ao consumidor, com vista à promoção da } \\
\text { contrapropaganda, pela Amil Assistência Médica Internação sem } \\
\text { resgate aéreo. }\end{array}$ & ICP 05/94 & 199 \\
\hline
\end{tabular}




\begin{tabular}{|c|c|c|c|}
\hline $\mathbf{N}^{\mathbf{o}}$ & MATÉRIA & REGISTRO & ART. \\
\hline 12 & $\begin{array}{l}\text { Representação 184/94. } \\
\text { Seguridade social. INSS. Atendimento. Apuração de } \\
\text { deficiências. }\end{array}$ & $\begin{array}{l}\text { ICP-PRDC } \\
\quad 05 / 94 \\
\quad / / \\
R \text { 184/94 }\end{array}$ & 194 \\
\hline 13 & $\begin{array}{l}\text { Direito constitucional. Orçamento de seguridade social, via } \\
\text { crédito extraordinário e suplementar para o Ministério do } \\
\text { Planejamento e da Educação. Afronta ao art.167, } \S 3^{\circ} \text {, da CF, e } \\
\text { ao art. } 43, \S 1^{\circ} \text {, III, da Lei 4320/64. }\end{array}$ & E 22/95 & 194 \\
\hline 14 & $\begin{array}{l}\text { Recebimento de benefício previdenciário e/ou tratamento } \\
\text { médico em virtude de deficiência física adquirida durante } \\
\text { período de incorporação ao Exército. }^{\checkmark}\end{array}$ & R 82/95 & 194 \\
\hline 15 & $\begin{array}{l}\text { Direito constitucional. Consumidor. Planos de saúde. Majoração } \\
\text { de mensalidade. Redução dos serviços. Opção forçada. }\end{array}$ & R 194/95 & 199 \\
\hline 16 & 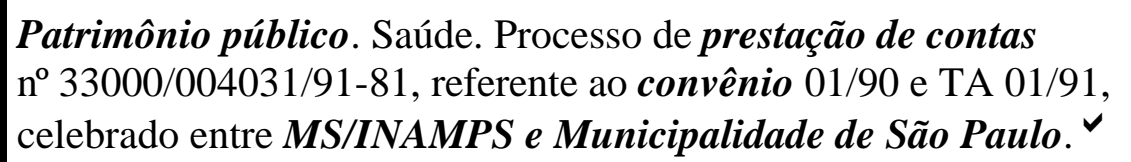 & R 220/95 & 37 \\
\hline 17 & $\begin{array}{l}\text { Patrimônio público e social. Sérias irregularidades na } \\
\text { importação de mercadorias pela Escola Paulista de Medicina da } \\
\text { UFSP. }\end{array}$ & $\begin{array}{l}R \quad 159 / 96 \\
\quad / / \\
\text { ICP } 15 / 96\end{array}$ & 37 \\
\hline 18 & $\begin{array}{l}\text { Irregularidade na importação de mercadorias pela Escola } \\
\text { Paulista de Medicina da UFSP. }\end{array}$ & $\begin{array}{l}\text { ICP } 15 / 96 \\
/ / \\
R \text { 159/96 }\end{array}$ & 37 \\
\hline
\end{tabular}


$\underline{M P F}$ - Demandas excluídas do universo de estudo pelo critério territorial

\begin{tabular}{|c|c|c|}
\hline $\mathbf{N}^{\mathbf{o}}$ & MATÉRIA & REGISTRO \\
\hline 1 & $\begin{array}{l}\text { Hospital dos Estivadores. Contribuição previdenciária. Apropriação } \\
\text { indébita. }\end{array}$ & CODID 27/91 \\
\hline 2 & Contaminação tóxica. São Vicente & CODID 01/92 \\
\hline 3 & $\begin{array}{l}\text { Atraso de repasse de recursos do INAMPS a hospitais públicos. } \\
\text { Santos }\end{array}$ & CODID 02/92 \\
\hline 4 & $\begin{array}{l}\text { ERSA } 13 \text { - Mogi das Cruzes. Aplicação de recursos } \\
\text { financeiros públicos. }\end{array}$ & CODID 10/92 \\
\hline 5 & $\begin{array}{l}\text { Fundação Casa de Misericórdia de Franca-SP. Irregularidade. } \\
\text { Desvio de verba / reutilização de material descartável. }\end{array}$ & CODID 46/93 \\
\hline 6 & $\begin{array}{l}\text { Irregularidades. Sr. Munir Bittar. Provedor da Fundação } \\
\text { Civil Casa de Misericórdia de Franca-SP. }\end{array}$ & CODID 70/93 \\
\hline 7 & $\begin{array}{l}\text { SUS. Irmandade Santa Casa de Misericóridia de Guarulhos. } \\
\text { Irregularidade na prestação de serviços médicos, com honorários em } \\
\text { duplicidade. }\end{array}$ & CODID 133/93 \\
\hline 8 & $\begin{array}{l}\text { Representação } 32 / 94 \text { - CODID/SP. } \\
\text { Apuração de irregularidade na gestão financeira da instituição de } \\
\text { saúde da Irmandade da Santa Casa de Misericórdia de Guarulhos. }\end{array}$ & ICP 01/94 \\
\hline 9 & Santa Casa de Guarulhos. Irregularidades. & CODID 32/94 \\
\hline 10 & Depósito de lixo atômico. Possibilidade de contaminação. ${ }^{\checkmark}$ & R $161 / 94$ \\
\hline 11 & $\begin{array}{l}\text { Idoneidade de documentos referentes a auditoria instaurada no INSS } \\
\text { de Santo André-SP. }\end{array}$ & R $165 / 94$ \\
\hline 12 & $\begin{array}{l}\text { Repasse de verbas federais para Hospital Municipal do Coração em } \\
\text { S.José do Rio Preto. }\end{array}$ & R 46/95 \\
\hline 13 & Irregularidades na Santa Casa de Panorama. & R 50/95 \\
\hline 14 & $\begin{array}{l}\text { Direito constitucional. Patrimônio público. Saúde pública. } \\
\text { Convênios. Fator de estímulo à municipalização. Legalidade. } \\
\text { Regularidade de repasses. Regularidade de convênios. Município de } \\
\text { Rolândia-SP. }\end{array}$ & R $155 / 95$ \\
\hline 15 & Idem. Município Dumont $\checkmark$ & R $156 / 95$ \\
\hline 16 & Idem. Município Cajobi ${ }^{\checkmark}$ & R $157 / 95$ \\
\hline
\end{tabular}




\begin{tabular}{|c|c|c|}
\hline $\mathbf{N}^{\mathbf{o}}$ & MATÉRIA & REGISTRO \\
\hline 17 & Idem. Município Nipo $\tilde{a}^{\checkmark}$ & R $158 / 95$ \\
\hline 18 & Idem. Município Taiaçu $\checkmark$ & R $159 / 95$ \\
\hline 19 & Idem. Município Valentim Gentil $\checkmark$ & R $160 / 95$ \\
\hline 20 & Idem. Município Pontal $\checkmark$ & R $161 / 95$ \\
\hline 21 & Idem. Município Paulo de Faria ${ }^{\checkmark}$ & R $162 / 95$ \\
\hline 22 & Idem. Município Sebastianópolis do Sul ${ }^{\checkmark}$ & R $163 / 95$ \\
\hline 23 & Idem. Município Serra Azul $\checkmark$ & R $164 / 95$ \\
\hline 24 & Idem. Centro de Reabilitação de Casa Branca. ${ }^{\checkmark}$ & R $176 / 95$ \\
\hline 25 & Idem. Hospital Regional de Osasco. $`$ & R $179 / 95$ \\
\hline 26 & Idem. Hospital São Lucas de Diadema. $\checkmark$ & R $185 / 95$ \\
\hline 27 & $\begin{array}{l}\text { Patrimônio público. Saúde. Faturamento de AIH. Regularidade. } \\
\text { Santa Casa de Barretos. } \checkmark\end{array}$ & R 196/95 \\
\hline 28 & Idem. Santa Casa de Misericórdia de Ribeirão Preto. $\checkmark$ & R 199/95 \\
\hline 29 & Idem. Santa Casa de São José do Rio Preto. ` & R 201/95 \\
\hline 30 & Idem. Assoc. Benef. dos Hosp. Sorocabana. ${ }^{\checkmark}$ & R 203/95 \\
\hline 31 & Convênio MS e Municipalidade de Ourinhos. ${ }^{\checkmark}$ & R 221/95 \\
\hline 32 & Convênio MS e Municipalidade de Campinas. $\checkmark$ & R 222/95 \\
\hline 33 & Convênio MS e Universidade Estadual de Campinas. ${ }^{\checkmark}$ & R 223/95 \\
\hline 34 & $\begin{array}{l}\text { Direito constitucional. Saúde pública. Denúncia de irregularidades e } \\
\text { mau funcionamento ocorridos no Hospital Público de Jandira/SP } \\
\text { após sua privatização há dois anos. }\end{array}$ & R 238/95 \\
\hline 35 & $\begin{array}{l}\text { Malversação de dinheiro público. SUS. Universidade Estadual do } \\
\text { Rio de Janeiro. } \checkmark\end{array}$ & R 255/95 \\
\hline 36 & $\begin{array}{l}\text { Direito constitucional. Direitos humanos. Prática de tortura, castigos } \\
\text { cruéis e tratamento psicológico inadequados. Hospital Psiquiátrico } \\
\text { Vera Cruz em Sorocaba/SP, Clínica de Repouso em Congonhas/SP } \\
\text { e Febem em Tatuapé/SP. }\end{array}$ & R $102 / 96$ \\
\hline
\end{tabular}




\begin{tabular}{c|l|c}
$\mathbf{N}^{\mathbf{0}}$ & \multicolumn{1}{|c}{ MATÉRIA } & REGISTRO \\
\hline $\mathbf{3 7}$ & $\begin{array}{l}\text { Direito constitucional. Denúncia de não-atendimento médico no HC } \\
\text { da Fac. Medicina do } \boldsymbol{A B C} .\end{array}$ & R 134/96 \\
\hline $\mathbf{3 8}$ & $\begin{array}{l}\text { Patrimônio público e social. Saúde. Dupra cobrança, pela Fundação } \\
\text { Civil Casa de Misericórdia de Franca, de internações hospitalares } \\
\text { do SUS e convênios particulares. }\end{array}$ & R 175/96 \\
\hline
\end{tabular}




\section{ANEXO 1-B}

Demandas registradas no Ministério Público Estadual

\begin{tabular}{|c|c|c|c|}
\hline $\mathbf{N}^{\mathbf{o}}$ & MATÉRIA & REGISTRO* & ART. \\
\hline 1 & $\begin{array}{l}\text { Apuração de eventual deficiência nos serviços na área da saúde } \\
\text { por falta de condições básicas. }\end{array}$ & $\begin{array}{r}\text { PJC } 128 / 93 \\
\text { Protoc.MP } \\
2736 / 93 \\
\text { IC } 31 / 93\end{array}$ & 200 \\
\hline 2 & $\begin{array}{l}\text { Denúncia de deficiência de atendimento médico e hospitalar em } \\
\text { postos de saúde. }\end{array}$ & $\begin{array}{r}\text { PJC 287/93 } \\
\text { Protoc.MP } \\
23415 / 93\end{array}$ & 200 \\
\hline 3 & $\begin{array}{l}\text { Denúncias de erros médicos contínuos e desídia sistemática por } \\
\text { parte de profissionais na área da saúde no Hospital de Ermelino } \\
\text { Matarazzo. }\end{array}$ & $\begin{array}{r}\text { PJC 303/93 } \\
\text { Protoc.PJ } \\
12908 / 91\end{array}$ & 197 \\
\hline 4 & $\begin{array}{l}\text { Ocorrência de seis mortes por infecção no berçário do Hospital } \\
\text { Maternidade V.Nova Cachoeirinha. }\end{array}$ & $\begin{array}{r}\text { PJC } 42 / 94 \\
\text { CAO } 234 / 95 \\
\text { Prot. } 2739 / 94\end{array}$ & 200 \\
\hline 5 & $\begin{array}{l}\text { Serviços públicos. Defesa do direito constitucional à vida e à } \\
\text { saúde. Apuração das causas e responsabilidades pela enchente } \\
\text { causada pelo transbordamento do Rio Aricanduva, em razão das } \\
\text { chuvas. Ocorrência de mortes e contaminação de pessoas por } \\
\text { leptospirose. }\end{array}$ & $\begin{array}{r}\text { PJC } 46 / 94 \\
\text { Protoc.MP } \\
97 / 94 \\
\text { IC } 7 / 94\end{array}$ & 200 \\
\hline 6 & $\begin{array}{l}\text { Apuração das mortes de } 25 \text { recém-nascidos no berçário da Santa } \\
\text { Casa de Santo Amaro. }\end{array}$ & $\begin{array}{r}\text { PJC } 47 / 94 \\
\text { CAO } 274 / 95 \\
\text { Prot. } 3782 / 94 \\
\text { IC } 08 / 94\end{array}$ & 200 \\
\hline 7 & $\begin{array}{l}\text { Denúncia sobre irregularidade no setor de saúde pública nas redes } \\
\text { estadual e municipal. }\end{array}$ & $\begin{array}{r}\text { PJC } 81 / 94 \\
\text { Protoc.PJ } \\
9694 / 94 \\
\text { IC } 19 / 95 \\
\text { PJ } 8785 / 94\end{array}$ & 198 \\
\hline 8 & $\begin{array}{l}\text { Apuração de dano ao patrimônio público em razão do } \\
\text { perecimento de gêneros alimentícios (carne bovina). }\end{array}$ & $\begin{array}{r}\text { PJC } 106 / 94 \\
\text { Protoc.PJ } \\
12668 / 94\end{array}$ & 200 \\
\hline
\end{tabular}

Codificação interna, com numerações referentes ao protocolo inicial e aos demais junto a cada órgão que atuou no caso. Embora não se tenha obtido informações precisas sobre o sistema de controle, o acesso aos autos foi facilitado pelo pessoal administrativo, que se encarregou da localização sempre que solicitado. 


\begin{tabular}{|c|c|c|c|}
\hline $\mathbf{N}^{\mathbf{o}}$ & MATÉRIA & REGISTRO* & ART. \\
\hline 9 & $\begin{array}{l}\text { Notícia de falta de atendimento médico que acarretou dois } \\
\text { óbitos em } 10.06 .94 \text {. }\end{array}$ & $\begin{array}{r}\text { PJC 109/94 } \\
\text { Protoc.PJ } \\
20211 / 94\end{array}$ & 196 \\
\hline 10 & $\begin{array}{l}\text { Apuração de poluição ambiental por detritos provenientes de } \\
\text { esgotos domésticos não canalizados. }\end{array}$ & \begin{tabular}{r|} 
PJC $121 / 94$ \\
Protoc.PJ \\
$22590 / 94$
\end{tabular} & 200 \\
\hline 11 & $\begin{array}{l}\text { Casa de repouso local em precário estado, expondo os pacientes } \\
\text { a condições degradantes. }\end{array}$ & $\begin{array}{r}\text { PJC 128/94 } \\
\text { CAO 364/94 }\end{array}$ & 200 \\
\hline 12 & $\begin{array}{l}\text { Precariedade das condições de atendimento de saúde pública na } \\
\text { zona norte da Capital. }\end{array}$ & \begin{tabular}{|r|} 
PJC $131 / 94$ \\
CAO 204/95 \\
Prot.19346/95
\end{tabular} & 200 \\
\hline 13 & $\begin{array}{l}\text { Graves ocorrências no atendimento médico envolvendo } \\
\text { pacientes de Diadema e o Hospital do Jabaquara. }\end{array}$ & $\begin{array}{r}\text { PJC 135/94 } \\
\text { CAO 664/96 }\end{array}$ & 200 \\
\hline 14 & Representação do $\boldsymbol{C} \boldsymbol{R} \boldsymbol{M}$. & $\begin{array}{r}\text { PJC } 159 / 94 \\
\text { CAO } 192 / 97\end{array}$ & 197 \\
\hline 15 & $\begin{array}{l}\text { Aplicação dos recursos provenientes do FUMDES - Fundo } \\
\text { Municipal de Saúde. }\end{array}$ & $\begin{array}{r}\text { PJC } 164 / 94 \\
\text { Protoc.PJ } \\
29 / 94\end{array}$ & 198 \\
\hline 16 & $\begin{array}{l}\text { Exercício irregular de atividade. Farmácia. Representação do } \\
\text { CRF/SP denunciando funcionamento ilegal de } 748 \\
\text { estabelecimentos. }\end{array}$ & $\begin{array}{r}\text { CAO } 413 / 94 \\
\text { Prot.29806/94 }\end{array}$ & 200 \\
\hline 17 & $\begin{array}{l}\text { Irregularidade na criação e implantação do PAS pela Secretaria } \\
\text { Municipal de Saúde. }\end{array}$ & $\begin{array}{r}\text { CAO 45/95 } \\
\text { Prot.35066/94 } \\
\text { IC 02/95 }\end{array}$ & 198 \\
\hline 18 & $\begin{array}{l}\text { Falta de seringa descartável na ARS- } 7 \text {. Uso de seringas de vidro. } \\
\text { Perigo de contaminação de doenças infecciosas. }\end{array}$ & $\begin{array}{r}\text { PJC 80/95 } \\
\text { Protoc.PJ } \\
8 / 95\end{array}$ & 200 \\
\hline 19 & $\begin{array}{l}\text { Interrupção na distribuição gratuita de preservativos masculinos } \\
\text { nos postos municipais de saúde. }\end{array}$ & $\begin{array}{r}\text { PJC 88/95 } \\
\text { CAO 342/96 }\end{array}$ & 196 \\
\hline 20 & Implantação do Conselho Municipal de Saúde. ${ }^{\checkmark}$ & $\begin{array}{r}\text { PJC } 121 / 95 \\
\text { Protoc.PJ } \\
25 / 95\end{array}$ & 198 \\
\hline 21 & $\begin{array}{l}\text { Desativação de parte de serviços de hospital. Interrupção de } \\
\text { atendimento à população. }\end{array}$ & $\begin{array}{r}\text { PJC } 127 / 95 \\
\text { CAO 596/95 } \\
\text { Prot. } 5327 / 95\end{array}$ & 196 \\
\hline
\end{tabular}




\begin{tabular}{|c|c|c|c|}
\hline $\mathbf{N}^{\mathbf{o}}$ & MATÉRIA & REGISTRO* & ART. \\
\hline 22 & $\begin{array}{l}\text { Desvio de finalidade exercido contra categoria de médicos } \\
\text { consistente no constrangimento para associação na implantação } \\
\text { do PAS. }\end{array}$ & $\begin{array}{r}\text { PJC } 142 / 95 \\
\text { CAO 38/96 } \\
\text { Prot. } 1172 / 95\end{array}$ & 198 \\
\hline 23 & $\begin{array}{l}\text { Atendimento pelo SUS. Ocorrência de quatro óbitos em pacientes } \\
\text { submetidos a hemodiálise. }\end{array}$ & $\begin{array}{r}\text { PJC 146/95 } \\
\text { CAO 341/96 }\end{array}$ & 200 \\
\hline 24 & $\begin{array}{l}\text { Deficiência no atendimento médico no Instituto de Infectologia } \\
\text { Emílio Ribas. } \\
\text { Interessado: CEDDPH } \\
\text { Requerido: SES }\end{array}$ & $\begin{array}{r}\text { PJC } 182 / 95 \\
\text { CAO } 318 / 95 \\
\text { Prot. } 18 / 95\end{array}$ & 200 \\
\hline 25 & $\begin{array}{l}\text { Distribuição de preservativos masculinos pela SMS, } \\
\text { contaminados por bactérias e fungos. }\end{array}$ & $\begin{array}{r}\text { PJC 207/95 } \\
\text { CAO 348/95 } \\
\text { Prot. } 3435 / 95\end{array}$ & 200 \\
\hline 1 & Desvio de verba do $\boldsymbol{F} \boldsymbol{U} \boldsymbol{M D E S}$ para custeio do PAS. & $\begin{array}{r}\text { PJC 212/95 } \\
\text { Protoc.PJ } \\
54 / 95\end{array}$ & 198 \\
\hline 2 & $\begin{array}{l}\text { Implantação do programa de redução de riscos de contaminação } \\
\text { de AIDS mediante a troca de seringas e agulhas para viciados. }\end{array}$ & $\begin{array}{r}\text { PJC 213/95 } \\
\text { CAO 319/95 } \\
\text { Prot. 23/95 } \\
\text { IC 23/95 }\end{array}$ & 200 \\
\hline 3 & $\begin{array}{l}\text { Apuração de omissão das autoridades em surto epidêmico de } \\
\text { meningite. }\end{array}$ & $\begin{array}{r}\text { PJC 237/95 } \\
\text { CAO } 732 / 96\end{array}$ & 200 \\
\hline 4 & $\begin{array}{l}\text { Projeto de lei sobre obrigatoriedade aos hospitais municipais de } \\
\text { realizarem gratuitamente laqueadura das trompas e vasectomia. }\end{array}$ & $\begin{array}{l}\text { PJC 262/95 } \\
\text { CAO 26/96 }\end{array}$ & 198 \\
\hline 5 & $\begin{array}{l}\text { Ilegalidade da Portaria } 35 / 95 \text {, que atribui o gerenciamento do } \\
\text { PAS à Secretaria Municipal de Planejamento, quando lei delega à } \\
\text { SMS. }\end{array}$ & $\begin{array}{r}\text { PJC 264/95 } \\
\text { CAO 330/96 }\end{array}$ & 198 \\
\hline 6 & Omissão de autoridades em risco epidêmico de meningite. & $\begin{array}{r}\text { PJC 273/95 } \\
\text { Protoc.PJ } \\
83 / 95\end{array}$ & 200 \\
\hline 7 & $\begin{array}{l}\text { Ineficiência do serviço público. Paralisação de ambulâncias. } \\
\text { Lesão ao erário. Publicidade do PAS em veículos oficiais. }\end{array}$ & $\begin{array}{l}\text { PJC } 321 / 95 \\
\text { Prot. } 93 / 95\end{array}$ & 198 \\
\hline 8 & Greve ocorrida no sistema de saúde da Capital. & $\begin{array}{r}\text { CAO } 323 / 95 \\
\text { Prot. 635/93 } \\
\text { PJC } 293 / 93 \\
\text { IC } 23 / 93\end{array}$ & 198 \\
\hline 9 & $\begin{array}{l}\text { Prestação de serviço de saúde pelo Posto de Saúde Moinho Velho } \\
\text { - Pirituba. }\end{array}$ & $\begin{array}{l}\text { Proc. } 327 / 95 \\
\text { Prot. } 97 / 95\end{array}$ & 200 \\
\hline
\end{tabular}




\begin{tabular}{|c|c|c|c|}
\hline $\mathbf{N}^{\mathbf{o}}$ & MATÉRIA & REGISTRO* & ART. \\
\hline 10 & $\begin{array}{l}\text { Desvio de material sob a guarda do Poder Público: hipófises } \\
\text { humanas de cadáveres sob exame do IML (Instituto Médico } \\
\text { Legal) e utilização indevida de veículo da administração. }\end{array}$ & $\begin{array}{r}\text { PJC 329/95 } \\
\text { Protoc.MP } \\
33224 / 95\end{array}$ & 200 \\
\hline 11 & Representação do $\boldsymbol{C R} \boldsymbol{M}$. & $\begin{array}{r}\text { PJC } 348 / 95 \\
\text { CAO } 167 / 97\end{array}$ & 197 \\
\hline 12 & $\begin{array}{l}\text { Aplicação irregular de recursos do FUMDES. Apuração de } \\
\text { responsabilidades. } \checkmark\end{array}$ & $\begin{array}{r}\text { PJC 349/95 } \\
\text { Protoc.PJ } \\
107 / 95 \\
\text { // PJC 393/96 } \\
\text { // PJC 453/96 }\end{array}$ & 198 \\
\hline 13 & $\begin{array}{l}\text { Apuração da qualidade e condições de atendimento médico- } \\
\text { hospitalar e eventuais práticas lesivas ao patrimônio público. }\end{array}$ & $\begin{array}{r}\text { CAO } 645 / 95 \\
\text { Prot. } 3165 / 95 \\
\text { IC } 11 / 96\end{array}$ & 200 \\
\hline 14 & $\begin{array}{l}\text { Denúncia sobre precárias condições de atendimento à saúde } \\
\text { pública em hospitais estaduais. }\end{array}$ & $\begin{array}{r}\text { PJC 045/96 } \\
\text { IC-PGJ 26/94 }\end{array}$ & 200 \\
\hline 15 & $\begin{array}{l}\text { Apuração de eventual superestimação da população } \\
\text { potencialmente cadastrada para o Módulo PAS da região } \\
\text { Pirituba/Perus. }\end{array}$ & $\begin{array}{r}\text { PJC 56/96 } \\
\text { Protoc PJ } \\
278 / 96\end{array}$ & 198 \\
\hline 16 & Inobservância de prioridade constante na CF, art. $198, \mathrm{II} .^{\checkmark}$ & $\begin{array}{r}\text { PJC } 121 / 96 \\
\text { Protoc.MP } \\
604 / 96\end{array}$ & 198 \\
\hline 17 & $\begin{array}{l}\text { Tomada de providências visando impedir que o } \boldsymbol{P A S} \text { deixe de } \\
\text { prestar tratamento médico a doentes de AIDS e câncer. }\end{array}$ & $\begin{array}{r}\text { PJC } 131 / 96 \\
\text { Protoc.PJ } \\
641 / 96\end{array}$ & 196 \\
\hline 18 & $\begin{array}{l}\text { Recusa no atendimento de urgência, a nível terciário, como } \\
\text { hospital de referência para o Município de Diadema. }\end{array}$ & $\begin{array}{r}\text { PJC 135/96 } \\
\text { Protoc.PJ } \\
668 / 96 \\
\text { Protoc.MP } \\
10 / 96\end{array}$ & 196 \\
\hline 19 & Adequação da prestação do serviço de saúde. & $\begin{array}{r}\text { Proc. 168/96 } \\
\text { Prot. 793/96 }\end{array}$ & 200 \\
\hline 20 & Apuração de irregularidades nas instalações físicas de hospital. & $\begin{array}{r}\text { PJC 172/96 } \\
\text { Protoc.PJ } \\
797 / 96\end{array}$ & 200 \\
\hline 21 & $\begin{array}{l}\text { Eventuais práticas de atos de improbidade pelo hospital no } \\
\text { gerenciamento dos recursos do } \boldsymbol{F U} \boldsymbol{M D E S} \text {. }\end{array}$ & $\begin{array}{r}\text { PJC 173/96 } \\
\text { Protoc.PJ } \\
798 / 96 \\
\text { Protoc.MP } \\
2736 / 96 \\
\text { IC } 31 / 93\end{array}$ & 198 \\
\hline
\end{tabular}




\begin{tabular}{|c|c|c|c|}
\hline $\mathbf{N}^{\mathbf{o}}$ & MATÉRIA & REGISTRO* & ART. \\
\hline 22 & $\begin{array}{l}\text { Ilegalidade na implantação do PAS junto ao Centro de Controle } \\
\text { de Zoonoses. Exercício do poder de polícia não validado em tal } \\
\text { situação. IN/SMS no 3/96: ausência de atos administrativos que } \\
\text { comprovassem a transferência do serviço para o PAS. }\end{array}$ & $\begin{array}{r}\text { PJC 252/96 } \\
\text { Protoc.PJ } \\
1039 / 96\end{array}$ & 198 \\
\hline 23 & Desativação de unidade do PAS (antiga UBS do Jardim Helian). & $\begin{array}{r}\text { PJC 260/96 } \\
\text { Protoc.PJ } \\
1108 / 96\end{array}$ & 196 \\
\hline 24 & $\begin{array}{l}\text { Apuração de violação do direito constitucional de atendimento à } \\
\text { saúde decorrente da desativação de serviços na UBS Penha de } \\
\text { França. }\end{array}$ & $\begin{array}{r}\text { PJC 263/96 } \\
\text { Protoc.PJ } \\
1133 / 96 \\
\text { Protoc.MP } \\
24416 / 96\end{array}$ & 196 \\
\hline 25 & Desrespeito à legislação sobre radiologia e auxiliares no Estado. & $\begin{array}{r}\text { PJC 264/96 } \\
\text { Protoc.PJ } \\
1134 / 96\end{array}$ & 197 \\
\hline 26 & $\begin{array}{l}\text { Falta de atendimento a pacientes internados no Hospital } \\
\text { Municipal Tide Setúbal. Ineficiência da prestação de serviço de } \\
\text { saúde. }\end{array}$ & $\begin{array}{l}\text { Proc. } 266 / 96 \\
\text { Prot.1138/96 }\end{array}$ & 196 \\
\hline 27 & $\begin{array}{l}\text { Falta de atendimento público de saúde de emergência em razão } \\
\text { da implantação do PAS. }\end{array}$ & $\begin{array}{l}\text { Proc. } 286 / 96 \\
\text { Prot. } 1200 / 96\end{array}$ & 196 \\
\hline 28 & $\begin{array}{l}\text { Apuração de eventual ilegalidade na remoção compulsória de } \\
\text { funcionários municipais na área da saúde, em decorrência da } \\
\text { implantação do PAS. }\end{array}$ & $\begin{array}{r}\text { PJC 288/96 } \\
\text { CAO 129/97 } \\
\text { Protoc.MP } \\
27370 / 96 \\
\text { Protoc.PJ } \\
1203 / 96\end{array}$ & 198 \\
\hline 29 & $\begin{array}{l}\text { Transferências ilegais de funcionários para exercício de funções } \\
\text { burocráticas em razão da implantação do PAS. }\end{array}$ & $\begin{array}{r}\text { PJC 329/96 } \\
\text { Protoc.PJ } \\
1309 / 96 \\
\text { Protoc. MP } \\
26159 / 96\end{array}$ & 198 \\
\hline 30 & $\begin{array}{l}\text { Providências relativas a deficiências no atendimento no serviço } \\
\text { de hemodiálise. }\end{array}$ & $\begin{array}{r}\text { PJC } 337 / 96 \\
\text { Protoc.PJ } \\
1385 / 96\end{array}$ & 200 \\
\hline 31 & Convênio Município/Estado - UBS. & $\begin{array}{r}\text { PJC 358/96 } \\
\text { CAO 163/97 } \\
\text { Protoc. PJ } \\
1434 / 96 \\
02 \text { Volumes }\end{array}$ & 198 \\
\hline 32 & Representação do $\boldsymbol{C} \boldsymbol{R} \boldsymbol{M}$. & $\begin{array}{r}\text { PJC } 365 / 96 \\
\text { CAO 161/97 }\end{array}$ & 197 \\
\hline
\end{tabular}




\begin{tabular}{|c|c|c|c|}
\hline $\mathbf{N}^{\mathbf{o}}$ & MATÉRIA & REGISTRO* & ART. \\
\hline 33 & $\begin{array}{l}\text { Prestação de serviço de relevância pública. Falta de fornecimento } \\
\text { de remédios à população pelas unidades de saúde. }\end{array}$ & $\begin{array}{r}\text { Proc. } 367 / 96 \\
\text { Prot.1537/96 }\end{array}$ & 196 \\
\hline 34 & $\begin{array}{l}\text { Repasse de verba da PMSP para o PAS em valor muito superior } \\
\text { àquele que corresponderia ao número de pessoas cadastradas. }\end{array}$ & $\begin{array}{r}\text { PJC 368/96 } \\
\text { Protoc.PJ } \\
1552 / 96\end{array}$ & 198 \\
\hline 35 & Liberação de recursos do $\boldsymbol{F U} \boldsymbol{M D E S} .^{\vee}$ & $\begin{array}{r}\text { PJC 383/96 } \\
\text { Protoc.PJ } \\
1684 / 96\end{array}$ & 198 \\
\hline 36 & $\begin{array}{l}\text { Indevida realocação de funcionário público da SMS em outras } \\
\text { Secretarias. }\end{array}$ & $\begin{array}{r}\text { PJC 387/96 } \\
\text { Protoc.PJ } \\
1725 / 96\end{array}$ & 198 \\
\hline 37 & $\begin{array}{l}\text { Apuração de irregularidades na utilização de verbas do } \\
\text { FUMDES: despesas com aquisição de telefax, reformas e } \\
\text { divisórias para a sede da ARS-4. }\end{array}$ & $\begin{array}{r}\text { PJC 393/96 } \\
\text { Protoc.PJ } \\
107 / 95\end{array}$ & 198 \\
\hline 38 & $\begin{array}{l}\text { Apuração de irregularidades na utilização de verbas do } \\
\text { FUMES: despesas com recuperação de elevadores do prédio } \\
\text { sede da SMS. }\end{array}$ & $\begin{array}{r}\text { PJC } 423 / 96 \\
\text { Protoc.PJ } \\
2092 / 96 \\
\text { IC } 22 / 96\end{array}$ & 198 \\
\hline 1 & $\begin{array}{l}\text { Apuração de irregularidades na utilização de verbas do } \\
\text { FUMDES: despesas com drenagem no poço do elevador do } \\
\text { prédio sede da SMS. } `\end{array}$ & $\begin{array}{r}\text { PJC } 425 / 96 \\
\text { Protoc.PJ } \\
2110 / 96 \\
\text { IC } 15 / 96\end{array}$ & 198 \\
\hline 2 & Representação do $\boldsymbol{C} \boldsymbol{R} \boldsymbol{M}$. & $\begin{array}{r}\text { PJC 426/96 } \\
\text { CAO 134/97 }\end{array}$ & 197 \\
\hline 3 & $\begin{array}{l}\text { Apuração de irregularidades nos hospitais conveniados ao PAS: } \\
\text { serviços deficientes. }\end{array}$ & $\begin{array}{r}\text { PJC 431/96 } \\
\text { Protoc.PJ } \\
2134 / 96 \\
\text { Protoc.MP } \\
40972 / 96\end{array}$ & 200 \\
\hline 4 & $\begin{array}{l}\text { Irregularidade na prestação de serviço público: recusa em } \\
\text { realização de cirurgia. }\end{array}$ & $\begin{array}{r}\text { PJC 448/96 } \\
\text { Protoc.PJ } \\
2094 / 96 \\
\text { Protoc.MP } \\
46449 / 96\end{array}$ & 196 \\
\hline 5 & $\begin{array}{l}\text { Apuração de irregularidade no remanejamento de médicos } \\
\text { veterinários para o cargo/função de médicos no Hospital } \\
\text { Municipal Artur Ribeiro de Saboya (PAS). }\end{array}$ & $\begin{array}{r}\text { PJC 449/96 } \\
\text { Protoc.PJ } \\
2235 / 96\end{array}$ & 197 \\
\hline
\end{tabular}




\begin{tabular}{|c|c|c|c|}
\hline $\mathbf{N}^{\mathbf{o}}$ & MATÉRIA & REGISTRO* & ART. \\
\hline 6 & $\begin{array}{l}\text { Apuração de irregularidades na utilização de verbas do Fundo } \\
\text { Municipal de Saúde - FUMDES. Despesas com equalização } \\
\text { salarial. } \checkmark\end{array}$ & $\begin{array}{r}\text { PJC } 452 / 96 \\
\text { Protoc.PJ } \\
2270 / 96 \\
\text { Protoc.MP } \\
107 / 95\end{array}$ & 198 \\
\hline 7 & $\begin{array}{l}\text { Apuração de irregularidades na utilização de verbas do } \\
\text { FUMDES } \checkmark\end{array}$ & $\begin{array}{r}\text { PJC } 453 / 96 \\
\text { Protoc.PJ } \\
107 / 95 \\
\text { IC } 014 / 96\end{array}$ & 198 \\
\hline 8 & $\begin{array}{l}\text { Apuração de irregularidade na utilização de verbas do } \boldsymbol{F U M D E S} \\
\text { despesas com aquisição de máquinas de escrever para setores }\end{array}$ & $\begin{array}{r}\text { PJC 454/96 } \\
\text { Protoc.PJ } \\
22725 / 96\end{array}$ & 198 \\
\hline 9 & $\begin{array}{l}\text { Apuração de irregularidades na utilização de verbas do } \\
\text { FUMES: despesas com aquisição de cadeiras, mesas, máquina } \\
\text { de assinar (sic), computadores, equipamentos de informática, } \\
\text { software e máquinas de somar para a sede da SMS. } \checkmark\end{array}$ & $\begin{array}{r}\text { PJC } 455 / 96 \\
\text { Protoc.PJ } \\
2273 / 96 \\
\text { Protoc.MP } \\
107 / 95 \\
\text { IC } 021 / 96\end{array}$ & 198 \\
\hline 10 & $\begin{array}{l}\text { Apuração de irregularidades na utilização de verbas do } \\
\text { FUMDES: despesa com pagamento de vale-refeição a servidores } \\
\text { da SMS. } \checkmark\end{array}$ & $\begin{array}{r}\text { PJC } 456 / 96 \\
\text { Protoc.PJ } \\
2235 / 96 \\
\text { IC } 17 / 96\end{array}$ & 198 \\
\hline 11 & $\begin{array}{l}\text { Apuração de irregularidades na utilização de verbas do } \\
\text { FUMDES: despesas com desapropriação do prédio anexo ao } \\
\text { Hospital do Servidor Público Municipal para montagem de creche } \\
\text { para filhos de funcionários, vestiários, setor de contabilidade, } \\
\text { tesouraria, velório e necrotério. } \checkmark\end{array}$ & $\begin{array}{r}\text { PJC } 457 / 96 \\
\text { Protoc.PJ } \\
1107 / 96 \\
\text { IC } 23 / 96\end{array}$ & 198 \\
\hline 12 & $\begin{array}{l}\text { Descumprimento da } L \boldsymbol{L} i \mathbf{7 3 9 4 / 8 5} \text {, que regula profissão de técnico } \\
\text { em radiologia. }\end{array}$ & $\begin{array}{r}\text { PJC } 463 / 96 \\
\text { Protoc.PJ } \\
2324 / 96 \\
\text { Protoc.MP } \\
463 / 96\end{array}$ & 197 \\
\hline 13 & $\begin{array}{l}\text { Apuração de prejuízo ao patrimônio público proporcionado pelo } \\
\boldsymbol{P A S} \text {. }\end{array}$ & $\begin{array}{r}\text { PJC 484/96 } \\
\text { Protoc.PJ } \\
2261 / 96 \\
\text { Protoc.MP } \\
48384 / 96\end{array}$ & 198 \\
\hline 14 & $\begin{array}{l}\text { Eventual omissão dos órgãos de vigilância sanitária, quanto ao } \\
\text { uso de denominações genéricas em produtos farmacêuticos. }\end{array}$ & $\begin{array}{r}\text { PJC } 487 / 96 \\
\text { Protoc.PJ } \\
2565 / 96 \\
\text { Protoc.MP } \\
35369 / 96\end{array}$ & 200 \\
\hline
\end{tabular}




\begin{tabular}{|c|c|c|c|}
\hline $\mathbf{N}^{\mathbf{o}}$ & MATÉRIA & REGISTRO* & ART. \\
\hline 15 & $\begin{array}{l}\text { Apuração de irregularidades no antigo terreno da municipalidade } \\
\text { (matadouro municipal), cujo muro está em ruínas e permite o } \\
\text { depósito de lixo e criação de roedores, o qual confronta com o } \\
\text { local em que os representantes residem. }\end{array}$ & $\begin{array}{r}\text { PJC } 495 / 96 \\
\text { Protoc.PJ } \\
2583 / 96\end{array}$ & 200 \\
\hline 16 & Desativação do Hospital da Vila Mariana. & $\begin{array}{r}\text { PJC 510/96 } \\
\text { Protoc.PJ } \\
2641 / 96\end{array}$ & 196 \\
\hline 17 & $\begin{array}{l}\text { Serviço público de saúde. Cobrança de valores indevidos na } \\
\text { prestação dos serviços do SUS. Enriquecimento ilícito. Atividade } \\
\text { nociva à comunidade usuária. }\end{array}$ & $\begin{array}{l}\text { Proc. } 528 / 96 \\
\text { Prot. 2802/96 } \\
\text { IC-PGJ 45/96 }\end{array}$ & 198 \\
\hline 18 & $\begin{array}{l}\text { Apuração de eventual violação da autonomia dos hospitais } \\
\text { universitários. }\end{array}$ & $\begin{array}{r}\text { PJC 534/96 } \\
\text { Protoc.PJ } \\
2816 / 96 \\
\text { Protoc.MP } \\
43162 / 96\end{array}$ & 198 \\
\hline 19 & $\begin{array}{l}\text { Eventual irregularidade em notificação encaminhada ao Centro } \\
\text { de Controle de Zoonozes, quanto aos prédios utilizados. }\end{array}$ & $\begin{array}{r}\text { PJC 555/96 } \\
\text { Protoc.PJ } \\
2871 / 96\end{array}$ & 200 \\
\hline 20 & $\begin{array}{l}\text { Circular distribuída a postos de saúde, a mando do requerido, } \\
\text { recomendando o uso de seringas de vidro na falta de } \\
\text { descartáveis. }\end{array}$ & $\begin{array}{l}\text { CAO } 638 / 96 \\
\text { PPIC } 08 / 95\end{array}$ & 200 \\
\hline 21 & $\begin{array}{l}\text { Proliferação do vírus HIV nas dependências da Casa de } \\
\text { Detenção (Carandiru). }\end{array}$ & $\begin{array}{r}\text { CAO } 648 / 96 \\
\text { IC } 12 / 96\end{array}$ & 200 \\
\hline 22 & $\begin{array}{l}\text { Garantia do direito constitucional de participação popular na } \\
\text { administração pública da saúde municipal. }\end{array}$ & CAO 719/96 & 198 \\
\hline 23 & $\begin{array}{l}\text { Distribuição gratuita dos medicamentos destinados a tratamento } \\
\text { de portadores do vírus da AIDS. }\end{array}$ & CAO 758/96 & 196 \\
\hline 24 & ICP $12 / 96$ do MPF, destinada a apurar o funcionamento do PAS. & $\begin{array}{r}\text { CAO } 901 / 96 \\
\text { Prot. } 48232 / 96\end{array}$ & 198 \\
\hline
\end{tabular}


MPE - Demandas excluídas do universo de estudo em razão da matéria

\begin{tabular}{|c|c|c|c|}
\hline $\mathbf{N}^{\mathbf{o}}$ & MATÉRIA & REGISTRO & ART. \\
\hline 1 & $\begin{array}{l}\text { Apuração de irregularidade na compra de lote de medicamento } \\
\text { AZT. }\end{array}$ & $\begin{array}{r}\text { CAO 822/92 } \\
\text { Prot.16022/92 }\end{array}$ & 37 \\
\hline 2 & $\begin{array}{l}\text { Encaminhamento do Proc. TC-A-9.287/026/92 acerca de } \\
\text { denúncias de irregularidades na contratação para fornecimento } \\
\text { de "AZT" pela SES. }\end{array}$ & $\begin{array}{l}\text { Proc. } 42 / 93 \\
\text { Prot. } 608 / 96\end{array}$ & 37 \\
\hline 3 & $\begin{array}{l}\text { Irregularidades na licitação para aquisição de kits para testes de } \\
\text { AIDS. }\end{array}$ & $\begin{array}{r}\text { PJC 50/93 } \\
\text { Protoc.MP } \\
30716 / 92 \\
\text { Protoc.PJ } \\
232 / 96 \\
\text { IC-PGJ 61/95 }\end{array}$ & 37 \\
\hline 4 & $\begin{array}{l}\text { Apuração de irregularidades nas contratações para } \\
\text { equipamentos hospitalares pela SES em 1990. Favorecimento nas } \\
\text { concorrências. }\end{array}$ & $\begin{array}{r}\text { Proc. } 91 / 93 \\
\text { Prot. } 326 / 96 \\
\text { IC-PGJ } 12 / 92\end{array}$ & 37 \\
\hline 5 & $\begin{array}{l}\text { Apuração de eventuais irregularidades na aquisição de produtos } \\
\text { alimentícios para detentos e funcionários. }\end{array}$ & $\begin{array}{r}\text { PJC 180/93 } \\
\text { Protoc.MP } \\
23613 / 91\end{array}$ & 37 \\
\hline 6 & $\begin{array}{l}\text { Irregularidades nos procedimentos licitatórios para aquisição de } \\
\text { materiais para o setor de diagnósticos, para anatomia patológica e } \\
\text { para microscopia do Hospital Ipiranga. }\end{array}$ & $\begin{array}{r}\text { PJC 267/93 } \\
\text { Protoc.MP } \\
24322 / 93\end{array}$ & 37 \\
\hline 7 & $\begin{array}{l}\text { Irregularidades em procedimentos licitatórios para aquisição de } \\
\text { material para imunologia do Hospital Ipiranga. }\end{array}$ & $\begin{array}{r}\text { PJC } 277 / 93 \\
\text { Protoc.MP } \\
24323 / 93 \\
\text { IC } 28 / 93\end{array}$ & 37 \\
\hline 8 & $\begin{array}{l}\text { Contratação irregular celebrada entre a SES e a empresa Apetece } \\
\text { - Sistemas de Alimentação Ltda. Dispensa indevida de licitação. }\end{array}$ & $\begin{array}{r}\text { PJC 281/93 } \\
\text { Protoc.PJ } \\
330 / 96 \\
\text { PPIC-PGJ } \\
24 / 94\end{array}$ & 37 \\
\hline 9 & $\begin{array}{l}\text { Contrato para fornecimento de refeições de pacientes e } \\
\text { funcionários do Hospital Geral de Vila Penteado. }\end{array}$ & $\begin{array}{r}\text { PJC 84/94 } \\
\text { Protoc.MP } \\
8152 / 94\end{array}$ & 37 \\
\hline 10 & Contratação irregular por parte da SES. & $\begin{array}{r}\text { PJC 90/94 } \\
\text { Protoc.MP } \\
8090 / 94\end{array}$ & 37 \\
\hline
\end{tabular}




\begin{tabular}{|c|c|c|c|}
\hline $\mathbf{N}^{\mathbf{o}}$ & MATÉRIA & REGISTRO & ART. \\
\hline 11 & $\begin{array}{l}\text { Apuração de notícia de compra, pela administração pública } \\
\text { estadual e municipal, por preço superior ao praticado no } \\
\text { mercado, de oxigênio líqüido para uso nos hospitais da rede } \\
\text { pública. }\end{array}$ & $\begin{array}{r}\text { PJC 150/94 } \\
\text { Protoc.PJ } \\
25938 / 94\end{array}$ & 37 \\
\hline 12 & $\begin{array}{l}\text { Ilegalidade de contrato. Preço consignado diverso do } \\
\text { apresentado pela contratada. }\end{array}$ & $\begin{array}{r}\text { PJC } 318 / 94 \\
\text { Protoc.PJ } \\
8160 / 94 \\
\text { IC-PGJ } 17 / 95\end{array}$ & 37 \\
\hline 13 & $\begin{array}{l}\text { Irregularidades na comprovação de contas do Instituto Dante } \\
\text { Pazzanese. }\end{array}$ & $\begin{array}{r}\text { PJC 83/95 } \\
\text { Protoc.MP } \\
33899 / 94\end{array}$ & 37 \\
\hline 14 & $\begin{array}{l}\text { Ilegalidade e irregularidades no convênio firmado entre a PMSP } \\
\text { e a Escola Paulista de Medicina para prestação de serviços } \\
\text { médicos e técnico-administrativos no Hospital de Vila Maria. }\end{array}$ & $\begin{array}{r}\text { PJC 97/95 } \\
\text { Protoc.MP } \\
37235 / 94 \\
\text { IC } 02 / 95-\mathrm{A}\end{array}$ & 37 \\
\hline 15 & $\begin{array}{l}\text { Propaganda do PAS. Violação da } \boldsymbol{C F}, \text { art.37, } \$ \mathbf{1}^{\boldsymbol{o}} \text {, e } \\
\text { Lei Orgânica Municipal, art.85. }\end{array}$ & $\begin{array}{r}\text { PJC } 124 / 95 \\
\text { Protoc.PJ } \\
28 / 95\end{array}$ & 37 \\
\hline 16 & $\begin{array}{l}\text { Apuração de eventual irregularidade em contratação pelo setor } \\
\text { de saúde do Município. }\end{array}$ & $\begin{array}{r}\text { PJC } 126 / 95 \\
\text { Protoc.PJ } \\
30 / 95 \\
\text { PPIC } 3 / 95\end{array}$ & 37 \\
\hline 17 & $\begin{array}{l}\text { Desvio de dinheiro público, ilegalidades em licitações, } \\
\text { enriquecimento ilícito no Hospital do Mandaqui. }\end{array}$ & $\begin{array}{r}\text { PJC } 137 / 95 \\
\text { Protoc. PJ } \\
13495 / 95\end{array}$ & 37 \\
\hline 18 & Irregularidades em licitação no âmbito da SMS. & $\begin{array}{l}\text { PJC } 172 / 95 \\
\text { Prot. } 42 / 95\end{array}$ & 37 \\
\hline 19 & $\begin{array}{l}\text { Contrato_firmado sem a realização de licitação para prestação de } \\
\text { serviços de documentação interna. Instalação e manutenção de } \\
\text { equipamentos de comunicação interna no PAM de Várzea do } \\
\text { Carmo. }\end{array}$ & $\begin{array}{r}\text { PJC 183/95 } \\
\text { Protoc.MP } \\
13580 / 95\end{array}$ & 37 \\
\hline 20 & Irregularidade na prestação de contas na SES. & $\begin{array}{r}\text { PJC 210/95 } \\
\text { Protoc.PJ } \\
1068 / 95\end{array}$ & 37 \\
\hline 21 & Apuração de responsabilidades referentes a empenho_(CVS-SES) & $\begin{array}{r}\text { PJC 268/95 } \\
\text { Protoc.PJ } \\
25600 / 95\end{array}$ & 37 \\
\hline
\end{tabular}




\begin{tabular}{|c|c|c|c|}
\hline $\mathbf{N}^{\mathbf{o}}$ & MATÉRIA & REGISTRO & ART. \\
\hline 22 & $\begin{array}{l}\text { Contratação irregular celebrada entre ERSA-13 e a empresa } \\
\text { Neve Ind. Com. Prods. Cirúrgicos Ltda. para aquisição de } \\
\text { material de enfermagem. }\end{array}$ & $\begin{array}{r}\text { PJC 319/95 } \\
\text { Protoc.MP } \\
8172 / 94 \\
\text { IC-PGJ } 19 / 95\end{array}$ & 37 \\
\hline 23 & $\begin{array}{l}\text { Contratação irregular celebrada entre a SES e a S/A White } \\
\text { Martins para fornecimento de oxigênio para o Hospital Zona Sul. }\end{array}$ & $\begin{array}{l}\text { Prot. } 320 / 95 \\
\text { IC } 21 / 95\end{array}$ & 37 \\
\hline 24 & $\begin{array}{l}\text { Eventual irregularidade em prestação de contas de aditamento em } \\
\text { nome do Diretor Administrativo do Hospital Vila Nova } \\
\text { Cachoeirinha durante o exercício de } 1992 .\end{array}$ & $\begin{array}{r}\text { PJC 323/95 } \\
\text { Prot.35001/95 }\end{array}$ & 37 \\
\hline 25 & $\begin{array}{l}\text { Suspensão da campanha publicitária do PAS. } \\
\boldsymbol{C F}, \boldsymbol{a r t . 3 7}, \boldsymbol{\$} \mathbf{1}^{\boldsymbol{o}} \text {. }\end{array}$ & $\begin{array}{r}\text { PJC 90/96 } \\
\text { Protoc.PJ } \\
356 / 96\end{array}$ & 37 \\
\hline 26 & Irregularidades nas contas das unidades de despesa. & $\begin{array}{r}\text { PJC } 116 / 96 \\
\text { Protoc.PJ } \\
561 / 96\end{array}$ & 37 \\
\hline 27 & $\begin{array}{l}\text { Irregularidade na contratação da PUC/Campinas, para o } \\
\text { programa de educação continuada para médicos do SUDS em } 87 .\end{array}$ & $\begin{array}{r}\text { PJC } 123 / 96 \\
\text { Protoc.PJ } \\
607 / 96\end{array}$ & 37 \\
\hline 28 & $\begin{array}{l}\text { Apuração de exercício irregular de função pública: improbidade } \\
\text { administrativa do Secretário de Saúde. }\end{array}$ & $\begin{array}{r}\text { PJC 124/96 } \\
\text { Protoc.PJ } \\
609 / 96 \\
\text { Protoc.MP } \\
4924 / 96\end{array}$ & 37 \\
\hline 29 & $\begin{array}{l}\text { Apuração de irregularidades no contrato celebrado em } 30.06 .90 \\
\text { entre a SES e o Banco de Sangue Paulista S/C Ltda., com } \\
\text { dispensa de licitação e sem o empenho de verbas. }\end{array}$ & $\begin{array}{r}\text { PJC 137/96 } \\
\text { Protoc.PJ } \\
710 / 96 \\
\text { Protoc.MP } \\
8149 / 94 \\
\text { IC-PGJ 10/94 }\end{array}$ & 37 \\
\hline 30 & $\begin{array}{l}\text { Apuração das irregularidades apontadas na perícia técnica } \\
\text { contábil realizada pela ARS-6 (São Miguel Paulista). }\end{array}$ & $\begin{array}{r}\text { PJC } 163 / 96 \\
\text { Protoc.PJ } \\
788 / 96\end{array}$ & 37 \\
\hline 31 & Apuração de ocorrência de atos de improbidade administrativa. & $\begin{array}{r}\text { PJC165/96 } \\
\text { CAO } 104 / 97 \\
\text { Protoc. PJ } \\
790 / 96\end{array}$ & 37 \\
\hline 32 & $\begin{array}{l}\text { Apuração de eventuais atos de improbidade administrativa } \\
\text { praticados na área da saúde municipal (DS-62 - Ermelino } \\
\text { Matarazzo) }\end{array}$ & $\begin{array}{r}\text { PJC 169/96 } \\
\text { Prot. } 794 / 96\end{array}$ & 37 \\
\hline
\end{tabular}




\begin{tabular}{|c|c|c|c|}
\hline $\mathbf{N}^{\mathbf{o}}$ & MATÉRIA & REGISTRO & ART. \\
\hline 33 & $\begin{array}{l}\text { Eventuais atos de improbidade administrativa praticados na área } \\
\text { da saúde pública. }\end{array}$ & $\begin{array}{r}\text { PJC } 174 / 96 \\
\text { Protoc.PJ } \\
799 / 96\end{array}$ & 37 \\
\hline 34 & $\begin{array}{l}\text { Apuração de legalidade do Decreto } 35.520 \text {, de } 26.09 .95 \text {. Abertura } \\
\text { de crédito suplementar de } \mathrm{R} \$ 10.140 .000,00 \text { destinado à } \\
\text { implantação do PAS. }\end{array}$ & $\begin{array}{l}\text { Proc. 175/96 } \\
\text { Prot. 800/96 }\end{array}$ & 37 \\
\hline \multirow[t]{2}{*}{35} & $\begin{array}{l}\text { Apuração de eventuais atos de improbidade administrativa } \\
\text { praticados no âmbito da SMS. }\end{array}$ & $\begin{array}{r}\text { PJC } 176 / 96 \\
\text { Protoc.PJ } \\
801 / 96\end{array}$ & 37 \\
\hline & $\begin{array}{l}\text { Eventual irregularidade na contratação da empresa Immunosay } \\
\text { Prods. Hospitalares Ltda. para fornecimento de materiais. }\end{array}$ & $\begin{array}{r}\text { PJC 190/96 } \\
\text { Protoc.PJ } \\
824 / 96\end{array}$ & 37 \\
\hline 36 & $\begin{array}{l}\text { Apuração de irregularidades em licitação pública promovida pela } \\
\text { SES e da SMS, com participação das empresas Phyton Fórmulas } \\
\text { Magistrais e Oficinais Ltda. e Pharmácia Artesanal Ltda. }\end{array}$ & $\begin{array}{r}\text { PJC 218/96 } \\
\text { Protoc.PJ } \\
938 / 96\end{array}$ & 37 \\
\hline 37 & $\begin{array}{l}\text { Apuração de irregularidades em contratos das Secretarias } \\
\text { Municipais. }\end{array}$ & $\begin{array}{r}\text { PJC 227/96 } \\
\text { Protoc.PJ } \\
978 / 96\end{array}$ & 37 \\
\hline 38 & $\begin{array}{l}\text { Apuração de superfaturamento dos luminosos colocados nas } \\
\text { unidades em funcionamento do PAS pela empresa Ferci } \\
\text { Comunicações Com.Ind.S/A. } \\
\text { Representante: Vereador Adriano Diogo } \\
\text { Representado: PMSP }\end{array}$ & $\begin{array}{r}\text { PJC 231/96 } \\
\text { Protoc.PJ } \\
993 / 96\end{array}$ & 37 \\
\hline 39 & $\begin{array}{l}\text { Denúncia de desvio de verbas na comissão de ensino do IAMSPE } \\
\text { para constituição da FAPECS (Fundação de Apoio à Pesquisa e } \\
\text { Ensino de Ciências da Saúde). }\end{array}$ & $\begin{array}{l}\text { Proc. } 254 / 96 \\
\text { Prot. } 283 / 96\end{array}$ & 37 \\
\hline 40 & $\begin{array}{l}\text { Irregularidades na contratação da empresa Belfort Segurança de } \\
\text { Bens e Valores S/C pela Secretaria de Saúde. }\end{array}$ & $\begin{array}{r}\text { PJC 271/96 } \\
\text { Protoc.PJ } \\
1163 / 96 \\
\text { Protoc.MP } \\
22744 / 96\end{array}$ & 37 \\
\hline 41 & $\begin{array}{l}\text { Apuração de irregularidades em contrato de compra de sal de } \\
\text { reidratação oral. }\end{array}$ & $\begin{array}{r}\text { PJC 296/96 } \\
\text { Protoc.PJ } \\
1232 / 96 \\
\text { Protoc.MP } \\
\text { 26341/96 }\end{array}$ & 37 \\
\hline 42 & $\begin{array}{l}\text { Apuração de irregularidades no contrato celebrado entre as } \\
\text { representadas, destinado a fornecimento de medicamentos. }\end{array}$ & $\begin{array}{r}\text { PJC } 341 / 96 \\
\text { Protoc.PJ } \\
1408 / 96 \\
\text { Protoc.MP } \\
11714 / 96\end{array}$ & 37 \\
\hline
\end{tabular}




\begin{tabular}{|c|c|c|c|}
\hline $\mathbf{N}^{\mathbf{o}}$ & MATÉRIA & REGISTRO & ART. \\
\hline 43 & $\begin{array}{l}\text { Apuração de atos de improbidade praticados por funcionários } \\
\text { municipais (furto de medicamentos). } \checkmark\end{array}$ & $\begin{array}{r}\text { PJC 364/96 } \\
\text { Protoc.PJ } \\
1518 / 96\end{array}$ & 37 \\
\hline 44 & $\begin{array}{l}\text { Irregularidades no contrato celebrado entre a SES, ERSA-43 e o } \\
\text { Hospital Maternidade de Cordeirópolis. }\end{array}$ & $\begin{array}{r}\text { PJC 396/96 } \\
\text { Protoc.PJ } \\
1804 / 96\end{array}$ & 37 \\
\hline 45 & $\begin{array}{l}\text { Apuração de irregularidades na aquisição de equipamentos } \\
\text { médico-hospitalares com dispensa de licitação em } 1990 .^{\vee}\end{array}$ & $\begin{array}{r}\text { PJC 402/96 } \\
\text { Protoc.PJ } \\
1619 / 96\end{array}$ & 37 \\
\hline 46 & $\begin{array}{l}\text { Contratação da empresa Rochamed Representações Comerciais } \\
\text { Ltda. pela Secretaria de Saúde. }\end{array}$ & $\begin{array}{r}\text { PJC 404/96 } \\
\text { Protoc.PJ } \\
1904 / 96 \\
\text { Protoc.MP } \\
37213 / 96\end{array}$ & 37 \\
\hline 47 & $\begin{array}{l}\text { Declaração de nulidade de Proc. 61.004.990-95: aquisição de } \\
\text { raticidas. }\end{array}$ & $\begin{array}{r}\text { PJC } 410 / 96 \\
\text { Protoc.PJ } \\
1989 / 96\end{array}$ & 37 \\
\hline 48 & $\begin{array}{l}\text { Irregularidades no contrato celebrado entre o IAMSPE (Instituto } \\
\text { de Assistência Médica do Servidor Público do Estado) e a } \\
\text { empresa Ticket Serviços Com. e Administração Ltda. }\end{array}$ & $\begin{array}{r}\text { PJC } 411 / 96 \\
\text { Protoc.PJ } \\
1993 / 96\end{array}$ & 37 \\
\hline 49 & $\begin{array}{l}\text { Realização de pagamentos superfaturados por cooperativa } \\
\text { integrante do PAS. }\end{array}$ & $\begin{array}{r}\text { PJC } 427 / 96 \\
\text { Protoc.PJ } \\
2114 / 96\end{array}$ & 37 \\
\hline 50 & $\begin{array}{l}\text { Tomada de providências em decorrência de decisão do TCE, que } \\
\text { julgou licitação ilegal e também contrato e despesas envolvendo a } \\
\text { Secretaria de Saúde. }\end{array}$ & $\begin{array}{r}\text { PJC 470/96 } \\
\text { Protoc. PJ } \\
2355 / 96 \\
\text { Protoc.MP } \\
14627 / 96\end{array}$ & 37 \\
\hline 51 & $\begin{array}{l}\text { Apuração de eventuais irregularidades em licitação para } \\
\text { aquisição de } 7.300 .000 \text { preservativos masculinos. }\end{array}$ & $\begin{array}{r}\text { PJC 512/96 } \\
\text { Protoc.PJ } \\
2647 / 96 \\
\text { Protoc.MP } \\
29763 / 94\end{array}$ & 37 \\
\hline 52 & Apuração de irregularidades em contratos celebrados pela SES. & $\begin{array}{r}\text { PJC 539/96 } \\
\text { Protoc.PJ } \\
2832 / 96 \\
\text { Protoc.MP } \\
21430 / 95 \\
\text { PPIC-PGJ } \\
32 / 95\end{array}$ & 37 \\
\hline
\end{tabular}




\begin{tabular}{c|l|c|c}
$\mathbf{N}^{\mathbf{0}}$ & \multicolumn{1}{|c|}{ MATÉRIA } & REGISTRO & ART. \\
\hline $\mathbf{5 3}$ & $\begin{array}{l}\text { Contratação. Dispensa de licitação. Primeira etapa de } \\
\text { reorganização do aprimoramento do sistema e melhoria de } \\
\text { produtividade e qualidade e controle orçamentário-financeiro dos } \\
\text { módulos do PAS. }\end{array}$ & $\begin{array}{l}\text { Proc. 570/96 } \\
\text { Prot.3110/96 }\end{array}$ & 37 \\
\hline
\end{tabular}




\section{ANEXO 2}

Roteiro de entrevista

1) Houve alterações estruturais internas na instituição em função da atribuição disposta no art.129, II, da Constituição Federal?

2) Percebe dificuldades para o cumprimento dessa atribuição em matéria de saúde? De que ordem: conceituais, operacionais? A que atribui tais dificuldades?

3) Quais os canais de captação de demandas em matéria de saúde?

4) Existe sistema de controle de sigilo sobre dados pessoais dos demandantes?

5) Quais outros "serviços de relevância pública" têm sido alvo de atuação?

6) Quais os critérios para triagem e distribuição de matérias limítrofes que envolvam, por exemplo, direito à saúde e direitos do consumidor?

7) Favor descrever brevemente o fluxo operacional das questões que envolvem matéria de saúde.

8) Existe atuação inter-institucional em matéria de saúde? Com que instituições? Como se dá essa interação?

9) Em casos de litisconsórcio facultativo, como se estabelece a relação com o Ministério Público Estadual / Federal?

Há definições de estratégias para atuação conjunta ou alternativa, conforme as peculiaridades do caso?

10) $\mathrm{Na}$ sua opinião, comparando atuação judicial com atuação extrajudicial, qual tem surtido melhor eficácia em matéria de saúde? Por que?

11) A instituição tem recomendação de matérias prioritárias, estratégias, diretrizes?

12) Como têm sido elaborados/cumpridos os Planos de Atuação Funcional (MPE) / os roteiros de atividades da Procuradoria dos Direitos do Cidadão (MPF)?

13) Acredita que eventuais dificuldades apontadas possam ser superadas mediante modificações na estrutura e/ou no funcionamento da instituição? Teria alguma sugestão para superar eventuais dificuldades? 